\title{
A Study of the Comparative Costs of Five Wet/Dry Cooling Tower Concepts
}

by

F. R. Zaloudek, R. T. Allemann, D. W. Faletti,

B. M. Johnson, H. L. Parry, G. C. Smith,

R. D. Tokarz and R. A. Walter

September 1976

Prepared for the Energy Research and Development Administration under Contract E(45-1)-1830

\section{Battelle}




\title{
NOTICE
}

This report was prepared as an account of work sponsored by the United States Government. Neither the United States nor the Energy Research and Development Administration, nor any of their employees, nor any of their contractors, subcontractors, or their employees, makes any warranty, express or implied, or assumes any legal liability or responsibility for the accuracy, completeness or usefulness of any information, apparatus, product or process disclosed, or represents that its use would not infringe privately owned rights.

\author{
PACIFIC NORTHWEST LABORATORY \\ operated by \\ BATTELLE \\ for the \\ ENERGY RESEARCH AND DEVELOPMENT ADMINISTRATION \\ Under Contract EY-76-C-06-1830
}
Printed in the United States of America
Available from
National Technical Information Service
U.S. Department of Commerce
5285 Port Royal Road
Springfield, Virginia 22151

Price: Printed Copys.

$\because$ Microtiche $\$ 3.00$

$\begin{array}{cc}\text {-Pages } & \text { NTIS } \\ 001-025 & \text { Selling Price } \\ 026-050 & \$ 4.50 \\ 051-075 & \$ 5.00 \\ 076-100 & \$ 5.50 \\ 101-125 & \$ 6.00 \\ 126-150 & \$ 6.50 \\ 151-175 & \$ 7.00 \\ 176-200 & \$ 7.75 \\ 201-225 & \$ 8.50 \\ 226-250 & 58.75 \\ 251-275 & 59.00 \\ 276-300 & \$ 10.00 \\ & \$ 10.25\end{array}$




\title{
33679000626889
}

A STUDY OF THE COMPARATIVE COSTS

OF FIVE WET/DRY COOL ING

TOWER CONCEPTS

\author{
by \\ F. R. Zaloudek \\ R. T. Allemann \\ D. W. Faletti \\ B. M. Johnson \\ H. L. Parry \\ G. C. Smith \\ R. D. Tokarz \\ R. A. Walter
}

September 1976

BATTELLE

Pacific Northwest Laboratories

Richland, Washington 99352 


\section{FOREWORD}

The Dry Cooling Tower Development Program at Battelle, Pacific Northwest Laboratory was initiated with a program scope that included the following near-term and ultimate emphases.

Near-Term Objectives:

- Develop economic and performance models for cost optimization of total heat rejection systems using dry cooling.

- Analyze, and disseminate operating experience on, existing drycooled plant performance.

- Demonstrate certain features of existing technology equipment to provide confidence for specification by utilities.

Ultimate Objective:

- Promote water conservation through industry use of dry cooling by developing and demonstrating the reliability of lower-cost systems. The development of advanced dry/wet systems is also considered to be within this scope.

Over the past two years the following documents have been issued, reporting the results of the work toward these objectives.

Cost optimization of dry-cooled heat rejection systems:

A REVIEW AND ASSESSMENT OF ENGINEERING ECONOMIC STUDIES OF DRY COOLED ELECTRICAL GENERATING PLANTS. B. C. Fryer, BNWL-1976, March 1976.

HEAT TRANSFER AND PRESSURE DROP CHARACTERISTICS OF DRY TOWER EXTENDED SURFACES. PART I: HEAT TRANSFER AND PRESSURE DROP DATA. PFR Engineering Systems, Inc., PFR 7-100, March 1976.

HEAT TRANSFER AND PRESSURE DROP CHARACTERISTICS OF DRY TOWER EXTENDED SURFACES. PART II: DATA ANALYSIS AND CORRELATION. PFR Engineering Systems, Inc., PFR 7-102, June 1976. 
Analysis of performance of existing dry-cooled plants:

DRY COOLING TOWER PROGRAM: RESULTS OF INDUSTRIAL CONTACTS THROUGH AUGUST 1974. BNWL-1878, November 1, 1974.

A SURVEY OF MATERIALS AND CORROSION PERFORMANCE IN DRY COOLING APPLICATIONS. A. B. Johnson, Jr., D. R. Pratt and G. E. Zima, BNWL-1958, March 1976.

EUROPEAN DRY COOLING TOWER OPERATING EXPERIENCE.

J. G. DeSteese and K. Simhan, BNWL-1995, March 1976.

MATHEMATICAL AND EXPERIMENTAL INVEST IGATIONS ON DISPERSION AND RECIRCULATION OF PLUMES FROM DRY COOLING TOWERS AT WYODAK POWER PLANT IN WYOMING. Y. Onishi and D. S. Trent, BNWL-1982, February 1976.

Advanced dry (dry/wet) cooled systems:

PRELIMINARY EVALUATION OF WET/DRY COOLING CONCEPTS FOR POWER PLANTS. W. V. Loscutoff, BNWL-1969.

COMPATIBILITY OF AMMONIA WITH CANDIDATE DRY COOL ING SYSTEM MATERIALS. D. R. Pratt, BNWL-1992, Apri1 1976.

SCALE FORMATION IN DELUGED DRY COOLING SYSTEMS. D. R. Pratt, BNWL-2060, March 1976.

AMMONIA AS AN INTERMEDIATE HEAT EXCHANGE FLUID FOR DRY COOLED TOWERS. R. T. Allemann, B. M. Johnson and G. C. Smith, BNWL-SA-5997, September 1976.

A group of reports (including this report) has recently been issued. This group serves the dual purpose of developing cost optimization models for dry cooling systems based on available technology and comparing the results of analyzing the costs of these systems with the projected cost of several advanced dry and dry/wet systems. Included in this group are:

AN ENGINEERING AND COST COMPARISON OF THREE DIFFERENT ALL-DRY COOLING SYSTEMS. B. C. Fryer, D. W. Faletti, Dan J. Braun, David J. Braun and L. E. Wiles, BNWL-2121, September 1976.

A STUDY OF THE COMPARATIVE COSTS OF FIVE WET/DRY COOLING TOWER CONCEPTS. F. R. Zaloudek, R. T. Allemann, D. W. Faletti, B. M. Johnson, H. L. Parry, G. C. Smith, R. D. Tokarz, and R. A. Walter, BNWL-2122, September 1976. 
DRY COOLING OF POWER GENERATING STATIONS A SUMMARY OF THE ECONOMIC EVALUATION OF SEVERAL ADVANCED CONCEPTS VIA A DES IGN OPTIMIZATION STUDY AND A CONCEPTUAL DESIGN AND COST ESTIMATE. B. M. Johnson, R. T. Allemann, D. W. Faletti, B. C. Fryer and F. R. Zaloudek, BNWL-2120, September 1976.

COSTS AND COST ALGORITHMS FOR DRY COOLING TOWER SYSTEMS. P. A. Ard, C. H. Henager, D. R. Pratt and L. E. Wiles, BNWL-2123, September 1976.

A USER'S MANUAL FOR THE BNW-I OPTIMIZATION CODE FOR DRY-COOLED POWER PLANTS. David J. Braun, Dan J. Braun, Warren V. De Mier, D. W. Faletti and L. E. Wiles, BNWL-2180, January 1977. 


\section{ACKNOWLEDGMENTS}

This report contains an account of the work sponsored by the Division of Nuclear Research and Applications of ERDA under the Dry Cooling Tower Project at Battelle, Pacific Northwest Laboratory (PNL). The project was completed under the direction of I. Helms, Project Officer; W. F. Savage, Manager of Advanced Concepts Evaluation Branch, ERDA Division of Nuclear Research and Applications; and B. M. Johnson, Manager of the Dry Cooling Tower Project at PNL.

In addition to the authors, the following personnel at PNL contributed to completion of the work: P. A. Ard, C. H. Henager, D. R. Pratt and A. J. Currie (Technical Editor).

The information provided by Dott. Ing. Carlo Rocco and Vincenzio Leonelli of Italimpianti, Genoa, Italy, and by Professor Carlo Roma of the University of Rome on the natural draft system currently under development by Italimpianti was of invaluable assistance in our evaluation of the induced draft PLASTIC system.

Acknowledgments are also due to the following cooling tower manufacturers and their representatives for their interest during this study: M. Larinoff and E. C. Smith of Hudson Products, R. Landon and R. Cates of Marley Company, and G. Wistran of Ecodyne Cooling Products.

Many manufacturers of components for cooling tower systems were contacted during the conduct of this study and provided essential cost information that was incorporated into the cost algorithms and estimates. This information is the basis of the comparisons made herein. We acknowledge this vital contribution to the study, although any mistakes in interpretation and formulization of this information are the responsibility of PNL. 


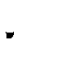




\section{SUMMARY}

The projected cost of five alternative dry/wet power plant heat rejection concepts was studied under conditions imposed by hypothetical use in association with the San Juan Plant Unit 3. The five alternative concepts were:

- integrated dry/wet tower

- separate dry and wet towers

- metal fin-tube induced draft tower with deluge water augmentation

- plastic heat exchanger tower with deluge water augmentation(a)

- metal fin-tube/deluge augmentation tower with an intermediate ammonia evaporation-condensation condenser and the cooling tower.

The integrated dry/wet tower concept was already chosen for service at San Juan Unit 3 and was included in the concepts under study for reference purposes. The San Juan Unit 3 is a 550-MWe facility currently under construction near the "Four Corners" area of New Mexico by the Publ ic Service Company of New Mexico. All concepts were conceptually designed and estimated using the same bases and employing uniform practices. Each concept was assumed to use all water allocated for consumptive use in Unit 3. Emphasis was placed on using components, equipment and materials which are currently available from established sources. All estimates were performed by Vitro Engineering, a division of Automation Industries, Inc. The ccst estimates obtained are listed below in order of descending "comparable capital cost." Comparable capital cost is defined as the sum of the basic estimated cost of each concept (less escalation and contingency) and the capitalized operating cost (based on a fixed charge rate of 18 percent).

\footnotetext{
(a) Natural draft plastic systems are under active investigation by Italimpianti in Italy. The plastic system studied here is a mechanical draft system using fabrication techniques applicable to U.S. construction practices. The differences between the plastic mechanical draft system and the Italimpianti natural draft system are sufficiently great that it is not possible to predict the competitiveness of the Italimpianti system by using the results shown here.
} 
Concept

Separate dry/wet

Metal fin-tube/deluge

Integrated dry/wet

Plastic tube/deluge

Metal fin-tube/deluge/ammonia
Basic Capital Cost

$\$ 29,276,000$

$28,882,000$

$22,789,000$

$24,344,000$

$23,152,000$
Capitalized Operating Cost

$$
\begin{array}{r}
\$ 14,330,000 \\
9,512,000 \\
11,836,000 \\
6,400,000 \\
5,342,000
\end{array}
$$

Comparable Capital Cost

$$
\begin{array}{r}
\$ 43,606,000 \\
38,394,000 \\
34,525,000 \\
30,744,000 \\
28,494,000
\end{array}
$$

The results indicate that two of the advanced concepts considered, i.e., the plastic tube/deluge concept and the metal fin tube/deluge/ammonia concept, can possibly reduce the overall costs of dry/wet cooling under conditions imposed by the site considered. It was recommended that these two concepts receive additional attention by the ERDA Dry Cooling Tower Program and industry to further quantify their potential benefits and demonstrate their performance and reliability. 
FOREWORD i i

ACKNOWLEDGMENTS

SUMMARY.

LIST OF FIGURES .

LIST OF TABLES

1.0 INTRODUCTION

1.1 BACKGROUND

1.2 ERDÁ/PNL DRY COOLING TOWER PROGRAM . . . . . . . . . 3

1.3 DRY/WET COOLING TOWER CONCEPTS SELECTION RATIONALE • • . . 4

2.0 BASES FOR COMPARISON. • . . . . . . . . . . . . . . . 7

2.1 GENERAL CRITERIA FOR COMPARISONS . . . . . . . . . . . . 7

2.2 CONCEPTUAL DESIGN BASES . . . . . . . . . . . . . . 8

3.0 RefERENCE PLANT DESCRIPTION . . . . . . . . . . . . . . . 11

3.1 LOCATION AND METEOROLOGY. • • • . • • • • . • • • . 11

3.2 DESCRIPTION OF REFERENCE UNIT . • • • • • • • • • • . . 11

3.3 WATER AVAILABILITY AND QUALITY. . . . . . . . . . . . 14

4.0 DESCRIPTION OF ALTERNATIVE DRY/WET COOLING TOWER CONCEPTS • • . 15

4.1 INTEGRATED DRY/WET COOLING TOWER CONCEPT . . . . . . . . 15

4.1.1 General Description. . . . . . . . . 15

4.2 SEPARATE DRY AND WET TOWERS. . . . . . . . . . . . . 23

4.2.1 General Description. . . . . . . . . . 23

4.3 METAL FIN-TUBE/DELUGE WATER AUGMENTATION . . . . . . . 38

4.3.1 General Description. . . . . . . . . . . 38

4.4 PLASTIC TUBE DELUGE WATER AUGMENTATION . . . . . . . . . 51

4.4.1 General Description. . . . . . . . . 51 
4.5 METAL FIN-TUBE/DELUGE AUGMENTATION/AMMONIA HEAT TRANSFER SYSTEM CONCEPT . . . . . . . . . . . . 64

4.5.1 General Description. . . . . . . . . . 64

5.0 BASES FOR COST ESTIMATES . . . . . . . . . . . . . . 75

5.1 CONSTRUCTION COSTS. . . . . . . . . . . . . . . . . 75

5.2 ANNUAL OPERATING COSTS . . . . . . . . . . . . . . 76

6.0 RESULTS . . . . . . . . . . . . . . . . . . . . 77

6.1 CAPITAL COSTS OF ALTERNATIVE CONCEPTS . . . . . . . . 77

6.2 OPERATING COSTS. . . . . . . . . . . . . . . . . . 79

6.3 COMPARATIVE CAPITAL SAVINGS. . . . . . . . . . . . 79

7.0 DISCUSSION . . . . . . . . . . . . . . . . . . . 81

7.1 POTENTIAL COST SAVINGS OF ALTERNATIVE CONCEPTS . . . . . 81

7.2 CONCLUSIONS AND RECOMMENDATIONS • • . . . . . . . . 84 REFERENCES. . . . . . . . . . . . . . . . . . . . . 85 


\section{FIGURES}

3-1 Site Plan for the San Juan Power Station . . . . . . . 12

4-1 Integrated Dry/Wet Tower Plan, Section and Elevation . . . 16

4-2 Integrated Dry/Wet Tower Cooling Water Piping System . . . 21

4-3 Site Plan for Separate Dry and Wet Towers . . . . . . . 25

4-4 Dry Cooling Tower Arrangement . . . . . . . . . . 26

4-5 Dry Cooling Tower Heat Exchanger . . . . . . . . . 27

4-6 Wet Cooling Tower Arrangement . . . . . . . . . . . 29

4-7 Wet Cooling Tower Cross Section . . . . . . . . . . 29

4-8 Packing for Wet Tower. . . . . . . . . . . . . . 31

4-9 Drift El iminator for Wet Tower. . . . . . . . . . 32

4-10 Dry Tower Piping Systen . . . . . . . . . . . . . 35

4-11 Wet Cooling Tower Piping System . . . . . . . . . . 37

4-12 Site Plan for Metal Fin-Tube/Deiuge Concept . . . . . . 41

4-13 Metal Fin-Tube/Deluge Tower Arrangement. . . . . . . . 42

4-14 Metal Fin-Tube/Deluge Heat Exchanger Unit . . . . . . . 43

4-15 Method of Applying Delugeate. . . . . . . . . . . 45

4-16 Metal Fin-Tube/Deluge Piping System . . . . . . . . . 48

4-17 Plastic Heat Exchanger Cooling Tower. . . . . . . . . 53

4-18 Plastic Heat Exchanger Cooling Tower:
Heat Exchanger Arrangement. . . . . . . . . . . 54

4-19 Plastic Tube Heat Exchanger Assembly. . . . . . . . . 55

4-20 Plastic Tube Heat Exchanger Schematic Drawing. . . . . . 56

4-21 Plastic Heat Tube Heat Exchanger:
Delugeate Application Details . . . . . . . . . . . 58

Plastic Heat Exchanger Cooling Tower:
Recirculation, Fill and Drain Piping. . . . . . . . . . 60 
4-23 Plastic Heat Exchanger Cooling Tower:

Deluge Piping System . . . . . . . . . . . . . . 62

4-24 Site Plan for Ammonia Concept . . . . . . . . . . . 66

4-25 Cooling Tower Arrangement for Ammonia

Dry Cooling Concept . . . . . . . . . . . . . 67

4-26 Ammonia Heat Transport System Piping. . . . . . . . . 71

4-27 Ammonia Concept: Delugeate Piping. . . . . . . . . 72

\section{TABLES}

3-1 Meteorological Profile at Farmington, New Mexico. . . . . 13

4-1 Integrated Dry/Wet Tower Design Parameters. . . . . . . 17

4-2 Integrated Dry/wet Tower Heat Exchanger Parameters . . . 18

4-3 Integrated Dry/Wet Tower Fan Specifications . . . . . . 19

4-4 Integrated Dry/wet Tower Condenser Details. . . . . . . 22

4-5 Dry Tower Design Parameters. . . . . . . . . . . . 24

4-6 Dry Tower Heat Exchanger Specifications. . . . . . . . 28

4-7 Wet Tower Design Parameters. . . . . . . . . . . . 30

4-8 Wet Cooling Tower Fill Specifications . . . . . . . . 30

4-9 Separate Dry and Wet Tower Concept Fan Specifications . . . 22

4-10 Condenser Specifications for Separate Dry/Wet Concept . . . 39

4-11 Design Information for Metal Fin-Tube/

Deluge Augmentation Concept. . . . . . . . . . . . 43

4-12 Heat Exchanger Specifications for Metal

4-13 Fan Specifications for Metal Fin-Tube/Deluge 
4-14 Plastic Heat Exchanger Deluge Augmentation Concept Design Information. . . . . . . . . . . . 54

4-15 Plastic Tube Heat Exchanger Design Specifications . . . . 57

4-16 Fan Specifications for Plastic Tube Deluge Augmentation Concept. . . . . . . . . . . 59

4-17 Ammonia Concept Design Information . . . . . . . . . 68

4-18 Specifications for Heat Exchangers Used for Ammonia Concept . . . . . . . . . . . . . . 68

4-19 Specifications of Fans Used for Ammonia Concept . . . . . 69

6-1 Results of Capital Cost Estimates of Alternative Heat Rejection Concepts for San Juan Unit 3 . . . . . . . . 77

6-2 Breakdown of Capital Costs of Alternative Concepts . . . . 78

6-3 Estimated Annual Operating Costs . . . . . . . . . . 79

6-4 Summary of Comparative Capital Costs. . . . . . . . . 80 


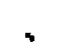




\section{A STUDY OF THE COMPARATIVE COSTS OF FIVE WET/DRY COOLING TOWER CONCEPTS}

\subsection{INTRODUCTION}

This report describes a cost study which compared the economics of five dry/wet cooling tower concepts for power plant cooling. These concepts are:

1. integrated dry/wet towers

2. separate dry and wet towers

3. metal fin-tube dry tower with deluge water augmentation

4. plastic tube dry tower with deluge augmentation

5. metal fin-tube dry tower with deluge augmentation and intermediate heat transport system utilizing ammonia evaporation/condensation.

Types 1 and 2 are state-of-the-art concepts and were included to provide the basis of comparison. Types 3, 4 and 5 can be considered as "advanced technology" concepts and have been previously identified as having potential for reducing the overall power costs for plants requiring wet/dry cooling. (a) A1l comparisons were performed on the basis of a common plant site--The Public Service Company of New Mexico, San Juan Unit 3 located in the "Four Corners" area of New Mexico.

\subsection{BACKGROUND}

In recent years, there has been an increasing interest in the use of dry cooling towers for steam power plant cooling. One of the principal reasons for this interest is the projected increase in competition for existing water supplies among a growing population, industry and agriculture. There are certain locations in the United States today where water is sufficiently scarce that it has been mandatory to build power plants with dry cooling towers.

(a) "Dry Cooling Tower Project Input to Revision of Project Justification, Strategy, and Plan," April 9, 1976. 
One of the problems with the use of dry cooling towers for power plants is the severe economic penalties associated with the unavoidably higher heat rejection temperature in warm weather than with an equivalent wet cooling tower. These higher heat rejection temperatures not only decrease the plant heat rate, making power more costly, but with conventional turbine designs, require the reduction of plant output on hot summer days when the power demands in the U.S. are likely to be highest. This loss of capacity would have to be compensated for by the availability of excess capacities in the plant or with the utilities system, or through the purchase of power.

Because of these economic penalties associated with dry cooling towers, there are strong incentives to augment them through evaporative cooling on hot days using any inexpensive water that may be available at the plant site. By such use of dry/wet cooling systems, both the plant efficiency and power loss problems can be ameliorated at the price of only a relatively small consumptive use of the available water resource as compared to usage of wet-only cooling towers. In a 1974 survey of utilities having potential cooling water availability problems, it was found that most saw the dry/wet cooling system as the most attractive option for plant construction in the 1980-2000 period.

There are a number of methods to combine dry and wet cooling systems. These methods include 1) separate dry and wet towers, 2) integrated dry and wet towers, 3) dry tower-cooling pond arrangements, 4) water spray augmentation, 5) water deluge augmentation and 6) water augmented dry towers with passive or active heat transport systems and others. There are a number of factors which enter into selection of a most economically advantageous option for a given plant site. These include water availability, fuel costs, water costs, elevation, climatology, etc. There is also less tangible consideration such as the availability of a power state-of-the-art technology. Recently, several articles and reports appearing in the literature have elucidated the economics of state-of-the-art integrated dry/wet tower and separate dry and wet tower systems. In this report, the economics of three additional "advanced" system concepts are considered. These concepts are: 
1. metal fin-tube dry tower with deluge water augmentation,

2. plastic tube dry tower with deluge augmentation, and

3. metal fin-tube dry tower with deluge water augmentation and with an ammonia evaporation-condensation heat transport system between the condenser and tower.

These concepts will be compared with each other and with the above-mentioned state-of-the-art systems on a uniform basis to gain insight regarding the potentially most advantageous system(s) for application under similar circumstances.

\subsection{ERDA/PNL DRY COOLING TOWER PROGRAM}

The objective of the Energy Research and Development Administration/ Pacific Northwest Laboratory (ERDA/PNL) Dry Cooling Tower Program is to develop, demonstrate and disseminate to potential users dry and wet/dry cooling tower technology which can be applied to conserve scarce water resources, increase power plant siting flexibility and result in a minimum degradation of power plant operation during yearly operation.

As currently planned, the Dry Cooling Tower (DCT) Program is divided into six separate tasks:

- TASK 1 Program planning and management

- TASK 2 Role of dry cooling in meeting national energy needs

- TASK 3 Cooperative testing and evaluation of dry cooling

- TASK 4 Anaiysis and design assessment of new dry cooling ideas

- TASK 5 Development of unique design features

- TASK 6 Planning and commercialization

This report presents work performed under Task 4 . The objective of this task is to provide critical appraisals of new technology or design concepts. Continuing appraisals, similar to the one reported here, will be performed through analytic evaluation, design studies and economic evaluation to normalize and compare claims of costs and performance of competing 
concepts. The results of this task will be used to identify the most advantageous concepts for further development and demonstration under Task 6 of this program.

\subsection{DRY/WET COOLING TOWER CONCEPTS SELECTION RATIONALE}

The concepts considered in this report were selected as a result of a series of preliminary studies of their potential thermodynamic and economic benefits. Some of the more important specific reasons for their inclusion are detailed below.

1. Integrated Dry/Wet Tower

The integrated dry/wet tower is the type planned for the San Juan Unit 3 and was included for reference and cost estimation validation purposes.

2. Separate Dry and Wet Towers

Recent studies of the use of separate dry and wet towers for power cooling applications $(1,2)$ have suggested several very important operational and cost advantages. These concepts were included in this study to quantify actual cost advantages of this rather simple application of existing technology.

3. Metal Fin-Tube with Deluge Augmentation Water augmentation (deluge) of a dry tower system has been under development in Europe and appears to have some important advantages. It is simpler to operate, can be operated with less water cleanup and possibly with cheaper tubing materials in the finned tubes. The use of water directly on the dry tower was felt to represent an advancement over the separate wet and dry towers in which the water flowing to the wet and the dry sections is kept separate by flow paths and/or by construction layout.

4. Plastic Tube Heat Exchanger with Deluge Augmentation

A heat exchanger utilizing plastic as a relatively inexpensive tube material has some potential for use in dry cooling towers. 
The plastic tubes are not subject to corrosion and are wellsuited for use with water augmentation. Other advantages include less likelihood of freezing damage and low susceptibility to fouling.

Natural draft plastic systems are under active investigation by Italimpianti in Itaiy. Pilot plant studies have been completed and the demonstration of a 75-MWe unit is planned. Italimpianti supplied PIL considerable information about their system. A review of this information indicated that the use of plastic heat exchangers offered promise. However, U.S. construction practices indicated that certain design modifications would make the plastic system more competitive in the U.S. Moreover, U.S. utilities have generally found mechanical draft systems more economical than natural draft systems. Therefore, PNL chose to investigate a mechanical draft, plastic system using the americanized design. This system is referred to as the PLASTIC system. The PLASTIC system differs so much from the Italimpianti system that it is not possible to predict the competitiveness of the Italimpianti system from the results obtained for the PLASTIC system.

5. Metal Fin-Tube Heat Exchanger with Deluge Augmentation and Intermediate Ammonia Heat Transport System

The use of ammonia rather than circulating water or direct steam condensation as an intermediate heat transfer medium between the turbine condenser and the air cooled exchanger appears to have the advantages of a higher heat transfer temperature difference in the cooling tower, smaller pipe lines for the fluid, reduced pumping requirements, and no freezing problems. Water augmentation can be used to increase the capabilities during hot ambient conditions, and reduce the size of the needed dry section.

The details of these concepts are described fully in Section 4.0 of this report. 
4 


\subsection{BASES FOR COMPARISON}

The criteria used to compare the five cooling tower concepts are described in detail in this section. Performance requirements on which the conceptual designs were based are also specified.

\subsection{GEINERAL CRITERIA FOR COMPARISONS}

Comparisons of the economics of the various concepts under study were performed on the basis of "Comparable Capital Costs." This is defined as the sum of the estimated capital costs of the cooling tower installation plus the capitalized operating cost. The capitalized operating cost was based on the assumption of an annual fixed charge rate of 18 percent.

Capital costs included all engineering, construction and material costs associated with the cooling towers, condenser, water treatment equipment and related piping and pumps. Included in construction costs were the contractor's profit and overhead. Operating costs included the costs of auxiliary power for pumps and fans, maintenance and water treatment.

Credit was taken for improvements in plant heat rate associated with lower back pressures made possible by the advanced designs. However, no credit was taken for increases in operating level that may have been made possible by lower back pressures than the design values of the reference plant.

To assure the validity of comparisons between the concepts under study every effort was made to employ uniformity in practice in the conceptual designs and cost estimation of each concept.

A11 estimates were prepared by an architect-engineer subcontractor (a) from preconceptual design descriptions prepared for each concept. All design descriptions utilized a common reference plant location, the San Juan Unit 3 of the Public Service Company of New Mexico. This plant, described in Section 3.0 of this report, was selected as the reference plant for this

$\overline{(a)}$ Vitro Engineering, a division of Automation Industries, Inc. 
study because a plant with integrated dry/wet cooling towers is currently under design and construction at this location. As a result, adequate data were already available on which to base the preconceptual designs of the advanced alternatives and to validate cost estimates. By basing the cost estimates on this common reference plant, it was possible to obtain common, representative values for all important design variables including:

- meteorology

- fuel costs

- water availability and quality

- onsite construction costs

- transportation costs

- power costs

- site characteristics.

Each of the dry/wet systems was conceptually designed and estimated using the same procedures, including the integrated wet/dry concept employed in the reference plant. No cost or detailed design information was obtained from the utility regarding the reference concept, so that it too was designed and costed on the same basis as the other four approaches. It is important to recognize that this cost comparison study is strictly applicable only to the reference plant design conditions. Other sites would have different conditions which could markedly affect the resulting comparison.

Further details regarding the preconceptual design bases are described in the following subsection.

\subsection{CONCEPTUAL DESIGN BASES}

The conceptual designs of the five cooling tower concepts were based on performance requirements established by the Public Service Company of New Mexico for the San Juan Unit 3. These requirements are listed below.

1. The heat rejection capability of the cooling system shall be $2.462 \times 10^{9} \mathrm{Btu} / \mathrm{hr}$ over a yearly cycle.

2. The cooling system shall accommodate the meteorological profile of Farmington, New Mexico. This profile is given in Subsection 3.1. 
3. The turbine shall be operated at or below a back pressure of $4.5 \mathrm{in}$. Hg at an ambient temperature of $95^{\circ} \mathrm{F}$ or below. Above $95^{\circ} \mathrm{F}$, the turbine back pressure shall be allowed to increase to a maximum of $5.0 \mathrm{in.} \mathrm{Hg.} \mathrm{This} \mathrm{requirement} \mathrm{was} \mathrm{set} \mathrm{for} \mathrm{this} \mathrm{study} \mathrm{to} \mathrm{provide}$ a basis for the water use consistent with the turbine capabilities It does not imply that the plant would be operated exactly in this way.

4. The maximum amount of water available annually for consumptive use is 1900 acre-ft or $5.13 \times 10^{9} 1 \mathrm{~b}$.

5. The maximum instantaneous consumptive water flow rate due to evaporation of delugeate shall be $2.0 \times 10^{6} \mathrm{lb} / \mathrm{hr}$ (4000 gpm).

6. The temperature range on the condenser cooling water shall be held constant at $24^{\circ} \mathrm{F}$, resulting in a cooling water flow rate of about $1.0958 \times 10^{8} \mathrm{ib} / \mathrm{hr}$.

The San Juan River was assumed to be the source of water to the plant. The assumed analysis of this river water is given in Subsection 3.3. Water treatment requirements for closed loop recirculating systems associated with dry towers were assumed to include demineralization, vacuum deaeration, corrosion inhibition and $\mathrm{pH}$ control ( $\mathrm{pH} 8.5$ ). Open loop systems used in wet and wet/dry towers were assumed to require lime-soda softening (side stream), scale inhibition and biofouling control. Delugeate treatment to maintain a Langlier saturation index of zero or slightly negative was assumed. The need for a zero hardness heat exchanger flush following shutdown of deluge was also assumed.

A11 conceptual designs were contained to reflect current industry practice for similar units. The design of the integrated dry/wet towers used for reference in this report was as close to the existing design of the San Juan Unit 3 towers as available information permitted. The plastic heat exchangers in concept 3 were designed to reflect design configurations and parameters used in earlier concept demonstrations performed in Italy. towers were conceptually designed to utilize components and materials of standard sizes and capacities, available from existing sources. 
Fu11 optimization of the concepts from the standpoint of all variables involved was not performed. Specifications for required "dry" performance were fixed by analysis of the anticipated deluge performance and an evaluation of the hours of the year and the ambient temperature range over which water would be available to augment performance. A computer code PLDEL was developed at PNL to establish the design point for all-dry operation. Finally, the proprietary design code of PFR, Inc. (code AC-2) was used to establish the dry tower parameters. Also, design details were not exhaustively optimized because of the preconceptual nature of the design activity. The details were principally governed by equipment and component sizes and capacities easily available from existing manufacturers and presently used in steam power generation design practice or in related areas. 


\subsection{REFERENCE PLANT DESCRIPTION}

The San Juan power station, used as the reference plant for this study, is described in this section. Significant site-specific parameters are documented in detail.

\subsection{LOCATION AND METEOROLOGY}

The San Juan power station is located at Waterflow, New Mexico in the "Four Corners" area of the state. The power station is owned jointly by Tucson Gas and Electric and the Public Service of New Mexico and is operated by the latter. Two units are currently in operation at the site; two additional units, including the reference unit (No. 3), are under design and construction. The units under construction, each 534 MWe (gross), are expected to be operational in 1979 and 1981. Units 1 and 2 are cooled by wet cooling towers. Units 3 and 4 will be cooled by Marley wet/dry units and are expected to save 60 percent of the water consumed by an all-wet tower. $A$ site plan is shown in Figure $3-1$.

The meteorological profile of the San Juan plant site is similar to that of nearby Farmington, described in Table 3-1. The site is at an elevation of approximately $5500 \mathrm{ft}$ and has an average barometric pressure of 0.815 atmospheres.

\subsection{DESCRIPTION OF REFERENCE UNIT}

The San Juan Station Unit 3 was chosen as the reference unit for this study. Much of the following information was provided by Public Service of New Mexico. Unit 3 is nominally rated at 500 MWe and will incorporate the first wet/dry towers used in this country for water conservation. These towers, made by the Marley Company, are rated at $2.5 \times 10^{9} \mathrm{Btu} / \mathrm{hr}$ over the yearly cycle and are designed to save 80 percent of the water consumed by an al1-wet tower of similar rating. The steam turbine is a conventional unit with allowable back pressure in the range of 1.0 to $5.0 \mathrm{in}$. $\mathrm{Hg}$. Back pressure will be maintained at less than $4.5 \mathrm{in}$. Hg at ambient temperatures below $95^{\circ} \mathrm{F}$, but will be allowed to rise to 5.0 at temperatures above $95^{\circ} \mathrm{F}$. The unit will be provided with a precipitator and $\mathrm{SO}_{2}$ scrubber. 


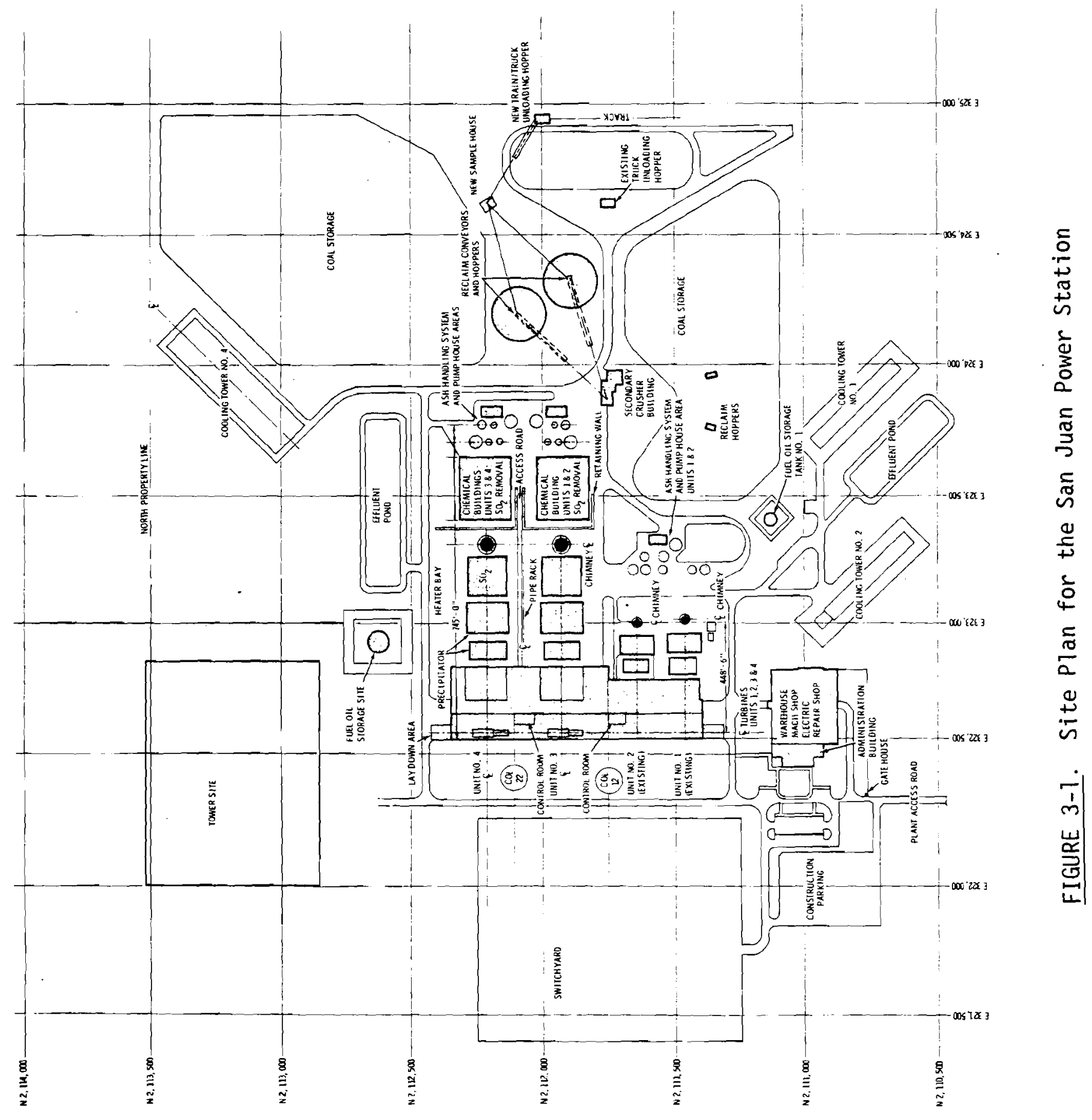


TABLE 3-1. Meteorological Profile at Farmington, New Mexico

\begin{tabular}{|c|c|c|}
\hline $\begin{array}{l}\text { Dry Bulb Air } \\
\text { Temperature }\left({ }^{\circ} \mathrm{F}\right)\end{array}$ & $\begin{array}{l}\text { Wet Bulb Air } \\
\text { Temperature }\left({ }^{\circ} \mathrm{F}\right)\end{array}$ & $\begin{array}{l}\text { Hours per } \\
\text { Year }\end{array}$ \\
\hline 7 & 7 & 55 \\
\hline 12 & 11 & 98. \\
\hline 17 & 16 & 198 \\
\hline 22 & 20 & 336 \\
\hline 27 & 25 & 553 \\
\hline 32 & 29 & 698 \\
\hline 37 & 33 & 688 \\
\hline 42 & 36 & 708 \\
\hline 47 & 39 & 678 \\
\hline 52 & 41 & 648 \\
\hline 55 & 44 & 388 \\
\hline 57 & 45 & 259 \\
\hline 62 & 47 & 704 \\
\hline 65 & 49 & 411 \\
\hline 67 & 50 & 274 \\
\hline 70 & 52 & 351 \\
\hline 72 & 53 & 234 \\
\hline 75 & 54 & 295 \\
\hline 77 & 54 & 197 \\
\hline 80 & 55 & 245 \\
\hline 82 & 56 & 164 \\
\hline 87 & 58 & 331 \\
\hline 92 & 61 & 179 \\
\hline 97 & 62 & 34 \\
\hline 102 & 63 & 1 \\
\hline
\end{tabular}




\subsection{WATER AVAILABILITY AND QUALITY}

Approximately 1900 acre-ft of water are available annually from the

San Juan River for consumptive use in the cooling towers of Unit No. 3 . The water is taken from the San Juan River and has the following assumed analysis:

Total Hardness

Calcium Hardness

Total Alkalinity

Sulfate

Total Dissolved Solids
$20-40 \mathrm{mg} / \mathrm{l}$ as $\mathrm{CaCO}_{3}$

15 - $30 \mathrm{mg} / \mathrm{l}$ as $\mathrm{CaCO}_{3}$

$10-25 \mathrm{mg} / \mathrm{l}$ as $\mathrm{CaCO}_{3}$

$10-15 \mathrm{mg} / \mathrm{l}$ as $\mathrm{CaCo}_{3}$

$50-100 \mathrm{mg} / \mathrm{l}$ 


\subsection{DESCRIPTION OF ALTERNATIVE DRY/WET COOLING TOWER CONCEPTS}

Details of the five cooling tower concepts are presented in this section. Design and site parameters are fully described, and component specifications are noted.

\subsection{INTEGRATED DRY/WET COOLING TOWER CONCEPT}

This heat rejection concept is the same as used in the San Juan Unit 3 and was included in this study to provide a basis for comparing the alternative concepts. To assure the validity of the comparisons, this concept, which is believed to approximate the system actually being constructed at the site, was conceptually designed and estimated using the same bases as the other concepts. That is, an attempt was made to make this conceptual design resemble the San Juan Unit 3 cooling towers with respect to physical arrangement and performance as closely as was possible with the limited information provided by the utility and cooling tower supplier. (a)

\subsubsection{General Description}

The heat rejection system is of the series indirect design, with water as the cooling medium followed by a wet tower. The cooling water receives thermal energy from condensing steam in a surface condenser. The heated cooling water is then transmitted to the cooling towers via a large diameter piping system. The cooling towers are rectangular in geometry and house the heat exchange surface. The heat exchanger is composed of spiral-wrapped finned tubes elevated $25^{\circ}$ from horizontal above an array of wet tower packing. Heat is transferred from the cooling water to the air stream passing over the outside heat exchange surfaces, and the cooled water is then dumped directly into the wet towers. The cooling tower is designed to operate as a completely dry system during the cooler periods of the year by bypassing the wet portion of the tower. When the air temperatures are sufficiently high, the wet portion of the tower is turned on to increase cooling capacity.

\footnotetext{
(a) Although the outline of the tower resembles the planned configuration, the particulars of the design were-developed independently of, and do not reflect the judgment or the practice of, the tower supplier or the user.
} 


\subsubsection{Cooling Tower Design Parameters}

A sketch of the proposed cooling tower is shown in Figure 4-1. Each rectangular cooling tower is capable of handling 50 percent of the heat load. The two cooling towers are located between north coordinates $2,112,800$ and $2,113,800$ and east coordinates 322,300 and 323,500 , as shown on the site plan, Figure 3-1.
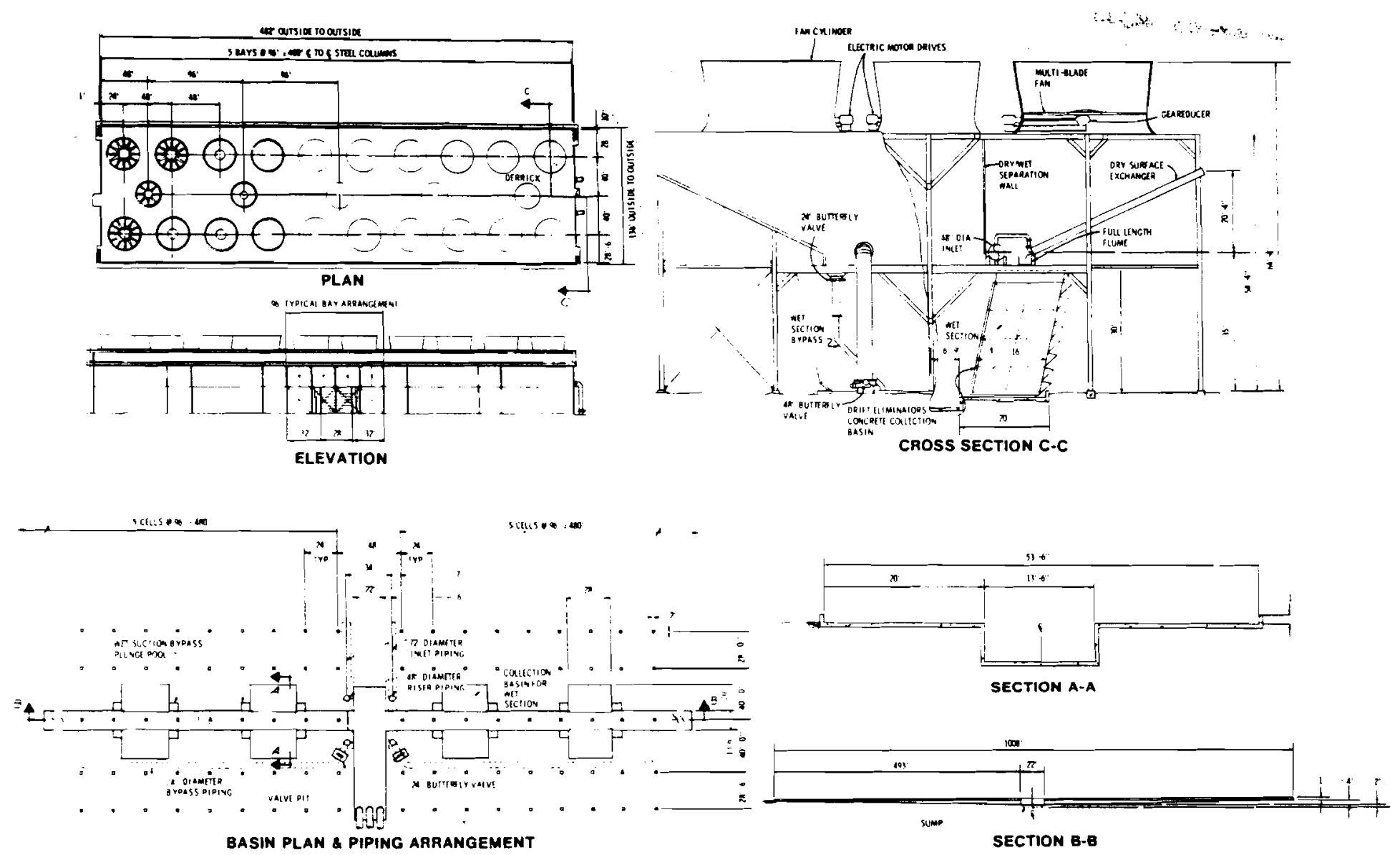

FIGURE 4-1. Integrated Dry/Wet Tower Plan, Section and Elevation

Each tower can be operated a11-dry, a11-dry and a11-wet, or fractions thereof. The air flow through each dry tower is induced mechanically with twenty 32-foot diameter fans mounted at the top of the tower structure, with five 26-foot diameter fans in the series wet section. The heat exchanger bundles (groups of 1448 tubes/96-ft bundle) are arranged in flat sections elevated $25^{\circ}$ from horizontal. A summary of the tower design parameters is provided in Table 4-1. 
TABLE 4-1. Integrated Dry/Wet Tower Design Parameters

Number of Towers:

Dry Tower Design Temperature:

Transverse Tube Pitch:

Air-Side Pressure Drop:

Unit Air Flow Rate Dry Section: Wet Section:

Cooling Water Flow Rate:

Air Flow Rate Dry Section:

Frontal Area of Heat Exchange

Total Surface Area:

Overall Heat Transfer Coefficient:

Number Passes:
2

$35^{\circ} \mathrm{F}$

2.345 in.

0.3452 in. $\mathrm{H}_{2} \mathrm{O}$ (corrected to exhaust air temperature and elevation)

$2382 \mathrm{lb} / \mathrm{hr}-\mathrm{ft} \mathrm{t}^{2}$

$1580 \mathrm{lb} / \mathrm{hr}^{-f t^{2}}$

$1.096 \times 10^{8} 1 \mathrm{~b} / \mathrm{hr}$

$2.196 \times 10^{8} \mathrm{lb} / \mathrm{hr}$

$9.216 \times 10^{4} \mathrm{ft}^{2}$

$7.206 \times 10^{6} \mathrm{ft}^{2}$

$6.41 \mathrm{Btu} / \mathrm{hr}-\mathrm{ft}{ }^{2}-{ }^{\circ} \mathrm{F}$

2

The design was based on the assumption that the total heat load could be rejected by the dry portion of the tower at ambient temperatures of $35^{\circ}$ or below. Above $35^{\circ} \mathrm{F}$, sections of the wet tower(s) must be activated to dissipate the specified quantity of heat. This design condition was determined through the use of a PNL code which determined the integrated amount of water required to augment the cooling capability of a dry tower of a prescribed size. Thus a dry tower capable of handling the entire plant heat load at $35^{\circ} \mathrm{F}$ would require the available 1900 acre-feet of water to meet the power requirements under the meteorological conditions at Farmington, New Mexico.

\subsubsection{Heat Exchangers}

There are 10 heat exchanger units per tower, two units in each bay. Specifications for these heat exchangers are provided in Table 4-2. 
TABLE 4-2. Integrated Dry/Wet Tower Heat Exchanger Parameters

Fin Design:

Fin Material:

Tube Material:

Tube OD:

Tube ID:

Fins/in.:

Fin OD:

Fin thickness:

Fin spacing:

Width of One Unit:

Depth of One Unit:

Length of One Unit:

Number of Tubes/96 ft Unit:

Tube Geometry:

Number of Units/Tower:

Number of Passes:

Air Flow Rate/Tower:

Cooling Water Flow Rate/Tower:
Single-leg wrapped

Aluminum

Admiralty

1.07 in.

0.93 in.

10

$2.25 \mathrm{in.}$

$0.018 \mathrm{in.}$

0.082 in.

$96 \mathrm{ft}$ in sections $12 \mathrm{ft}$ wide

10 in.

$48 \mathrm{ft}$

1448

Staggered, equilateral

10

2

$2.56 \times 10^{7} \mathrm{cfm}$

$5.48 \times 10^{7} \mathrm{lb} / \mathrm{hr}$

\subsubsection{Fans}

A total of 26 induced draft fans was specified for each tower, 20 in the dry section and 5 in the wet section. Specifications for these fans are provided in Table 4-3.

Louvers may be required on both air intake faces of each cooling tower for air flow control during high winds and for equalizing the flow distribution into each bay. However, none have been specified.

\subsubsection{Water Flow System}

The piping system for the cooling towers consists of cooling water pumps, concrete distribution piping between the condenser and heat exchange headers (collection basin and return), water treatment, elbows and tees, reducers and vaives. 
TABLE 4-3. Integrated Dry/Wet Tower Fan Specifications

\begin{tabular}{|c|c|c|}
\hline \multirow[b]{2}{*}{ Fan Diameter $(f t)$ : } & Dry Sections & Wet Sections \\
\hline & 32 & 24 \\
\hline Blade Material: & Fiberglass & Fiberglass \\
\hline Number of Blades: & 12 & 6 \\
\hline Blade Angle: & $16^{\circ}$ & $16^{\circ}$ \\
\hline Fan Speed $(r p m):$ & 120 & 156 \\
\hline Flow Rate/Fan: & $1,364,000 \mathrm{cfm} 090^{\circ} \mathrm{F}$ & $702,000 \mathrm{cfm} 0109^{\circ} \mathrm{F}$ \\
\hline hp/Fan: & 210 & 90 \\
\hline Bell Material: & Steel & Stee 1 \\
\hline \multicolumn{2}{|c|}{ Velocity Recovery Stack (ft): 18} & 18 \\
\hline Stack Material: & Fiberglass & Fiberglass \\
\hline Number of Fans/Tower: & 20 & 5 \\
\hline Total Number of Fans: & 40 & 10 \\
\hline Blades: & Manually adjusted & Manually adjusted \\
\hline Drive: & Gear train. & Gear train \\
\hline
\end{tabular}

The piping system supplies cooling water to the general area of the cooling towers through 96-in. diameter buried concrete pipe that is approximately $1400 \mathrm{ft}$ long. The return line is similar. During cold weather, the towers can be bypassed completely to allow a reasonable temperature rise in the water before entering the towers. At the tower end of the 96-in. line, the flow is first separated into two 72-in. lines. The 72-in. lines are then split into two 48-in. lines for each of the two towers.

The 48-in. lines (two per tower runing parallel down the tower length) supply circulating water to 6 -in. diameter lines every $12 \mathrm{ft}$ along the length of two bays, $192 \mathrm{ft}$. At this point the lines are reduced to $36-\mathrm{in}$. diameter for the remaining $288 \mathrm{ft}$, again with 6-in. diameter lines off the 36-in. diameter lines. Each 6-in. diameter line goes to a 12-ft wide, twopass, three-row bundle containing 182 tubes. After passing through the bundle the circulating water may either be distributed into the wet sections in the center of each group of 8 to $12-\mathrm{ft}$ wide bundles, or it may be bypassed 
through two 24-in. wet section bypasses, one on either side of the wet section. The water is collected in the tower basin and flows to a sump where it is pumped to the condenser through a 96-in. diameter line by three 73,000-gpm (77 ft head) vertical well pumps.

The basin has the capacity to hold in excess of 150,000 gal. of water or the entire inventory of the cooling tower. When the cooling system goes off-line, the water in the cooling tower will drain into the tower basin. The 122,000-gal. addition should raise the water level in the basin about $1.0 \mathrm{ft}$. The water in the basin may be drained to the influent pond by operation of the makeup drain pump. The water in the remaining piping is gravity-drained by a separate line from the lowest point (near the condenser) to the influent pond. The makeup line also acts as the fill piping and is capable of providing sufficient operating water in about $7 \mathrm{hr}$. The piping system is shown in Figure 4-2.

The San Juan River will provide makeup water for the recirculating water system. A flow of $4000 \mathrm{gpm}$ will be pumped to the influent pond to allow settling of solids. Makeup water will be taken from the pond. Water treatment will be performed in a side-stream treatment plant with 1000-gpm capacity. Treatment will consist of lime-soda softening dispersant addition (phosphonate and polyacrylate), scale inhibition $\left(\mathrm{H}_{2} \mathrm{SO}_{4}\right)$ and biofouling control (chlorine plus supplemental quarternary ammonium/ tributyl tin oxide). The treatment facility will consume $105 \mathrm{gpm}$ for washing and dilution.

\subsubsection{Condenser}

A single water box condenser is used and has a heat rejection capacity of $2.46^{2} \times 10^{9} \mathrm{Btu} / \mathrm{hr}$ with a water flow rate of $219,000 \mathrm{gpm}$. Further details regarding the condenser are provided in Table 4-4. 


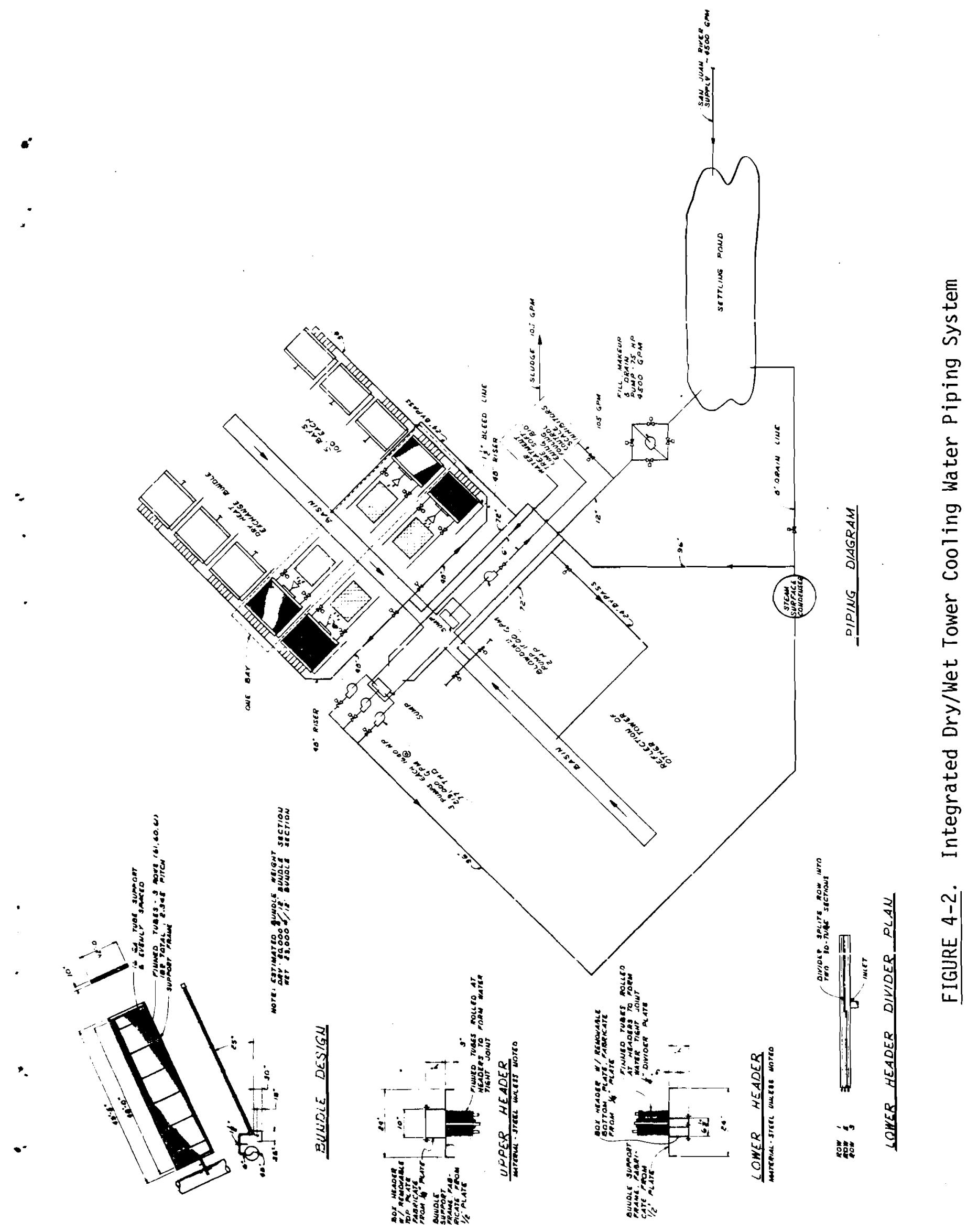


TABLE 4-4. Integrated Dry/Wet Tower
Condenser Details

$\begin{array}{ll}\text { Tube Diameter: } & 1 \mathrm{in} . \\ \text { Tube Length: } & 35 \mathrm{ft} \\ \text { Tube Gauge: } & 20 \mathrm{BWG} \\ \text { Tube Material: } & \text { Admiralty } \\ \text { Air Removal Section: } & \text { Stainless Steel } \\ \text { Number of Tubes: } & 28,500 \\ \text { Tube Geometry: } & \text { Square }\end{array}$

\subsubsection{Control and Instrumentation}

The overall control of the cooling tower is accomplished through the use of a microprocesser. Important control functions include:

- fan control

- drain control for freeze protection

- startup bypass controls

- water quality control

- dry/wet split control

- water use monitoring

- meteorological measurement

- back pressure control

- emergency shutdown procedures.

This cooling system will be operated in an automatic mode with the aid of a microprocesser when the ambient air temperature and relative humidity are within certain set 1 imits. At $35^{\circ} \mathrm{F}$ or below, the system will be automatically operated all-dry at the lowest possible back pressure. Above this temperature, the control system will automatically determine the amount of wet operation required.

In this automatic mode the microprocesser will receive input information including:

- turbine back pressure

- plant heat load 
- ambient air temperature

- relative humidity

- tower status

- current amount of wet operation

- cumulative water usage

- wind velocity and direction

- chemical treatment

- selected water temperatures through the system.

The microprocesser will analyze input data and take appropriate action to maintain the desired back pressure and economic water use. The control systen wi11 record system components or segments which are out of service.

\subsection{SEPARATE DRY AND WET TOWERS}

\subsubsection{General Description}

This heat rejection system is of the indirect type and utilizes two separate and distinct recirculating loops serving the wet and dry towers, respectively. The condenser is a split water-box divided surface condenser, which has separate water circuits for the dry tower recirculating system and the wet tower system.

The dry cooling tower for this heat rejection system is an induced mechanical draft tower with finned tubes as the heat exchange surface. Cooling water is passed through these tubes with air flow induced over the outside of the tubes. Sensible heat transfer to the air cools the water which is finally returned to the "dry side" of the surface condenser. The evaporative, or wet cooling, tower used in this system is a counterflow mechanically induced draft design, with the majority of water cooling accomplished by partial evaporation of the water into air induced through the tower.

The dry tower is designed to operate the year around; the wet tower is designed to be operated only during periods of high ambient temperatures. This system was designed for location at the site presently planned for insta1lation of the Marley integrated dry/wet tower. 
The split condenser is located within the turbine building. The three dry cooling towers and the wet tower are located between north coordinates $2,112,800$ and $2,113,500$, and east coordinates 321,700 and 322,800 , as indicated on the site plan of Figure 4-3. The dry towers are approximately $185 \mathrm{ft}$ in diameter and are spaced $120 \mathrm{ft}$ apart. The wet tower is $340 \mathrm{ft}$ by $56 \mathrm{ft}$ and is located a minimum of $200 \mathrm{ft}$ from the nearest dry tower.

\subsubsection{Dry Cooling Tower Parameters}

The design of the dry cooling tower is illustrated in Figure 4-4. Each dry tower will handle 10 percent of the heat load at $95^{\circ} \mathrm{F}$ and 33 percent of the heat load at $35^{\circ} \mathrm{F}$ and lower. All three towers are designed to operate throughout the year. Air flow through each tower is induced mechanically with 14 fans, each with a diameter of $32 \mathrm{ft}$. All fans are mounted at the top of the tower structure on a fan deck. The heat exchanger bundles (groups of 160 finned tubes) are arranged in vertical A-frames. Air flow through these bundles is perpendicular to the tubes. Protection for the heat exchange surfaces is provided by louvers around the circumference of each tower.

A summary of design parameters is provided in Table 4-5.

\section{TABLE 4-5. Dry Tower Design Parameters}

Dry Tower Design Temperature:

Transverse Tube Pitch:

Static Air Pressure Drop:

Unit Air Flow Rate:

Cooling Water Flow Rate:

Air Flow Rate:

Design ITD:

Frontal Area of Heat Exchanger:

Total Number of Heat Exchanger Tubes:

Overal1 Heat Transfer Coefficient:

Total Surface Area: $35^{\circ} \mathrm{F}$

2.375 in.

0.45 in. $\mathrm{H}_{2} \mathrm{O}$

$5,427 \mathrm{lb} / \mathrm{hr}-\mathrm{ft}^{2}$

$1.09 \times 10^{8} \mathrm{lb} / \mathrm{hr}$

$2.196 \times 10^{8} \mathrm{lb} / \mathrm{hr}$

$89.68^{\circ} \mathrm{F}$

$99,072 \mathrm{ft}^{2}$

15,360

$6.41 \mathrm{Btu} / \mathrm{hr}-\mathrm{ft}^{2}-{ }^{\circ} \mathrm{F}$

$8.06 \times 10^{6} \mathrm{ft}^{2}$ 


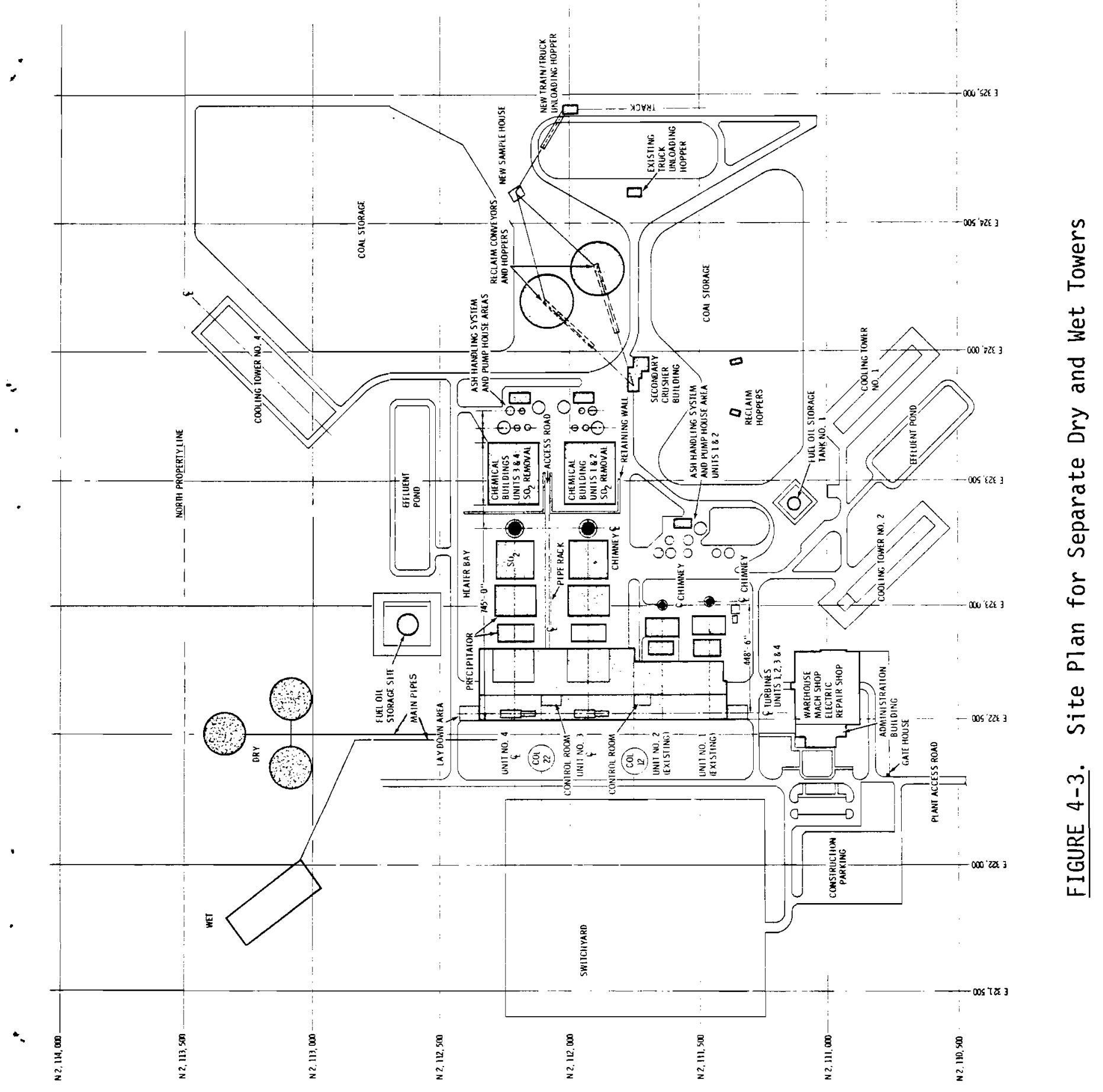




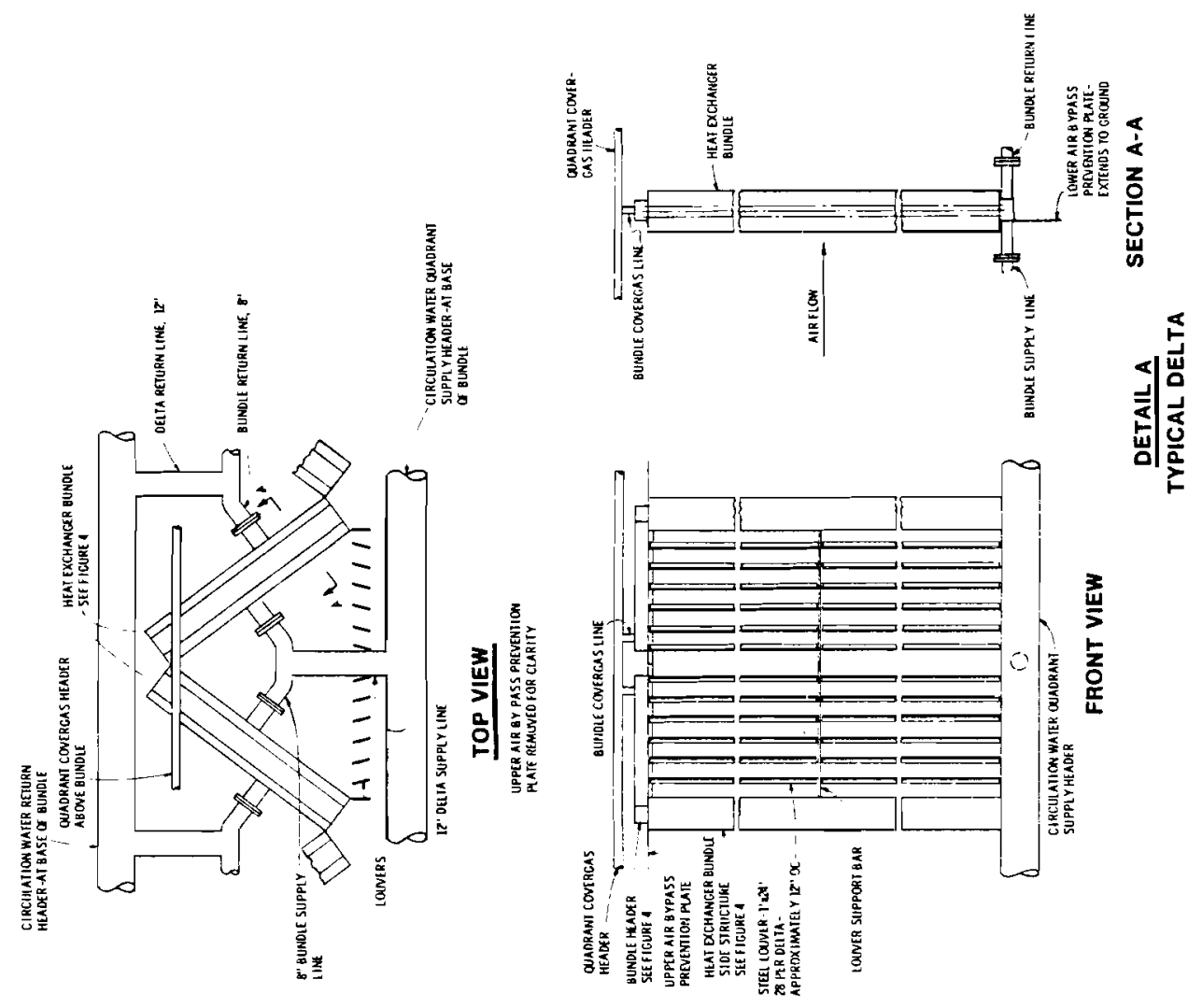

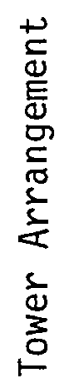
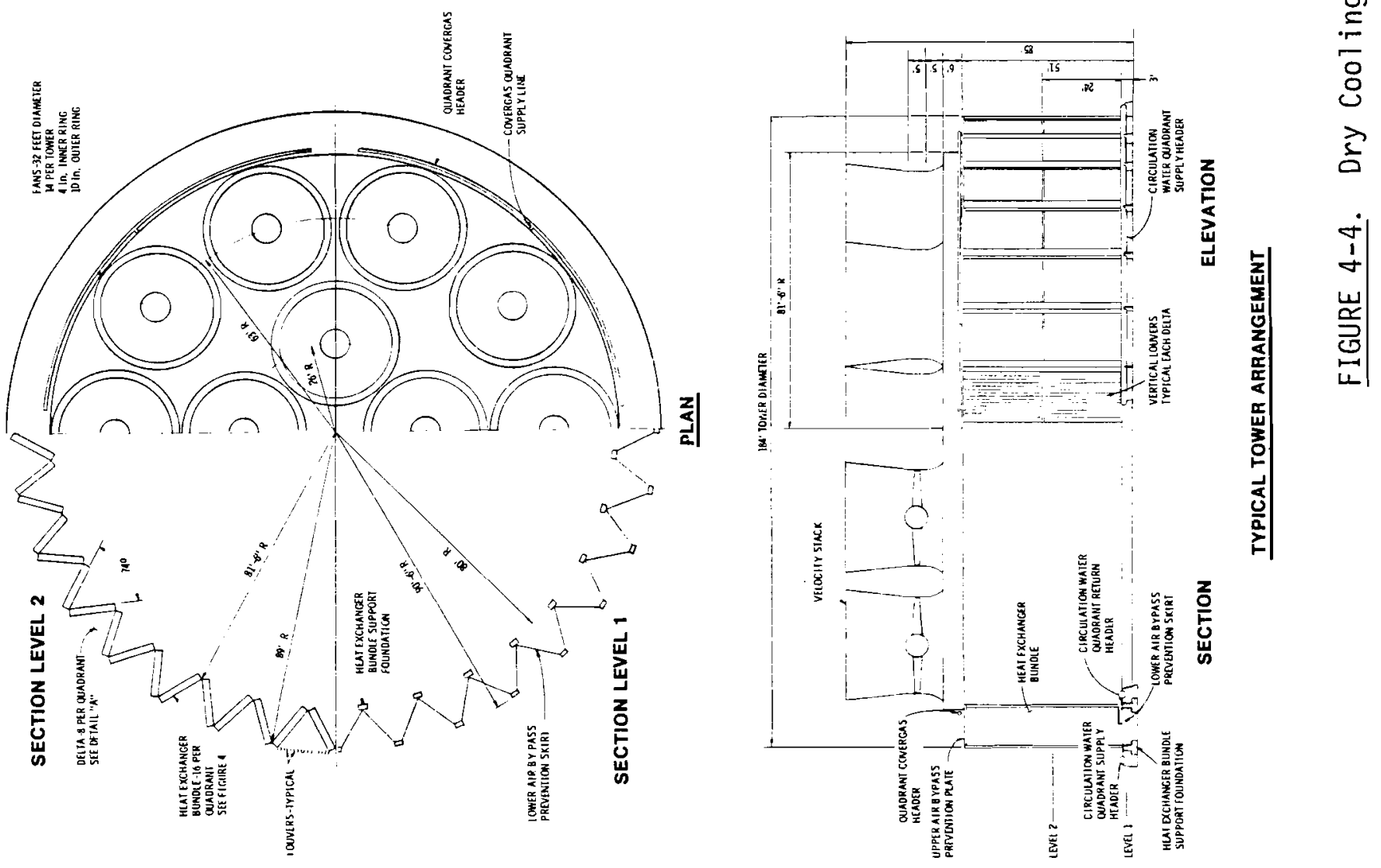


\subsubsection{Dry Tower Heat Exchangers}

The dry tower heat exchanger design is shown in Figure 4-5. Each bundle contains 160 tubes $(48 \mathrm{ft}$ ) with 3 rows deep $(54,52,54)$. The tubes are staggered on an equilateral pitch with a transverse spacing of 2.375 in. The tubes are arranged for two-pass, with the appropriate header design. Each bundle is preassembled with a 24 in. $\times 3$ in. $\times 3 / 8$ in. channel on each edge of the bundle. The bundles are approximately $491 / 2 \mathrm{ft}$ long, $103 / 4 \mathrm{ft}$ wide, and $10 \mathrm{in.} \mathrm{deep.} \mathrm{The} \mathrm{bundles} \mathrm{are} \mathrm{arranged} \mathrm{in} \mathrm{vertical} \mathrm{A-frames} \mathrm{in} \mathrm{the} \mathrm{dry}$ tower, with an apex angle of $74^{\circ}$.

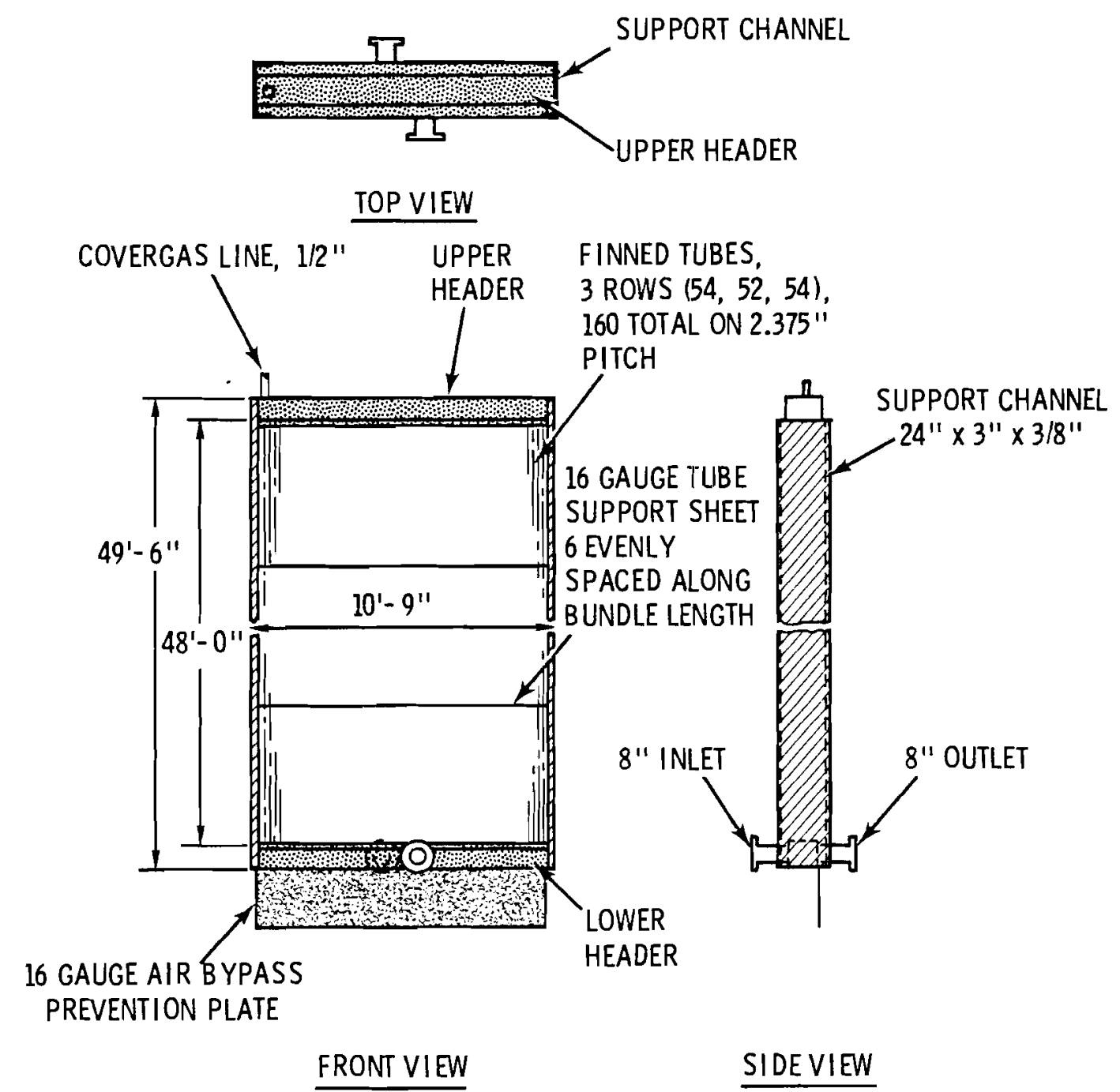

FIGURE 4-5. Dry Cooling Tower Heat Exchanger 
A single bundle, including tubes, headers, and supports, weighs approximately 15,000 1b. When this bundle is filled with cooling water, its weight is approximately $18,4001 \mathrm{~b}$.

Specifications for the heat exchangers are provided in Table 4-6.

\title{
TABLE 4-6. Dry Tower Heat Exchanger Specifications
}

\author{
Type: \\ Fin-Tube \\ Materials: \\ Aluminum extruded fins; carbon stee \\ tubes \\ Tube 00: \\ $1.070 \mathrm{in.}$ \\ Tube ID: \\ $0.93 \mathrm{in.}$ \\ Spacing: \\ 10 fins/in. (0.082 in.) \\ Fin OD: \\ $2.25 \mathrm{in}$. \\ Fin Thickness: \\ 0.018 \\ Width of One Bundle: \\ $10 \mathrm{ft}-9$ in. \\ Depth of One Bundle: \\ $10 \mathrm{in.}$ \\ Length of One Bundle: \\ $49 \mathrm{ft}-6$ in. \\ Number of Tubes/Bundle: \\ 160 \\ Tube Geometry: \\ Staggered, equilateral \\ Number of Bundles/A-Frame: \\ 2 \\ Number of A-Frames/Tower: \\ 32 \\ Number of A-Frames/Tower Quadrant: 8 \\ Air Flow Rate/Tower: \\ $1.627 \times 10^{7} \mathrm{cfm}$ \\ Cooling Water Flow Rate/Tower: \\ $3.633 \times 10^{7} \mathrm{lb} / \mathrm{hr}$ \\ Louver Orientation: \\ Vertical \\ Louver Dimension: \\ $1 \mathrm{ft} \times 24 \mathrm{ft}$ \\ Number of Louvers/A-Frame: \\ 28 \\ Numbers of Louvers/Tower: \\ 896 \\ With this dry tower design, the entire heat load from the plant can be \\ rejected at ambient temperatures of $35^{\circ} \mathrm{F}$ or below. Above $35^{\circ} \mathrm{F}$, the wet \\ tower must be utilized.
}




\subsubsection{Wet Cooling Tower Parameters}

The wet cooling tower is designed to handle 70 percent of the total heat load at an ambient temperature of $95^{\circ} \mathrm{F}$. Details of the conceptual design are given in Figures $4-6$ and 4-7.
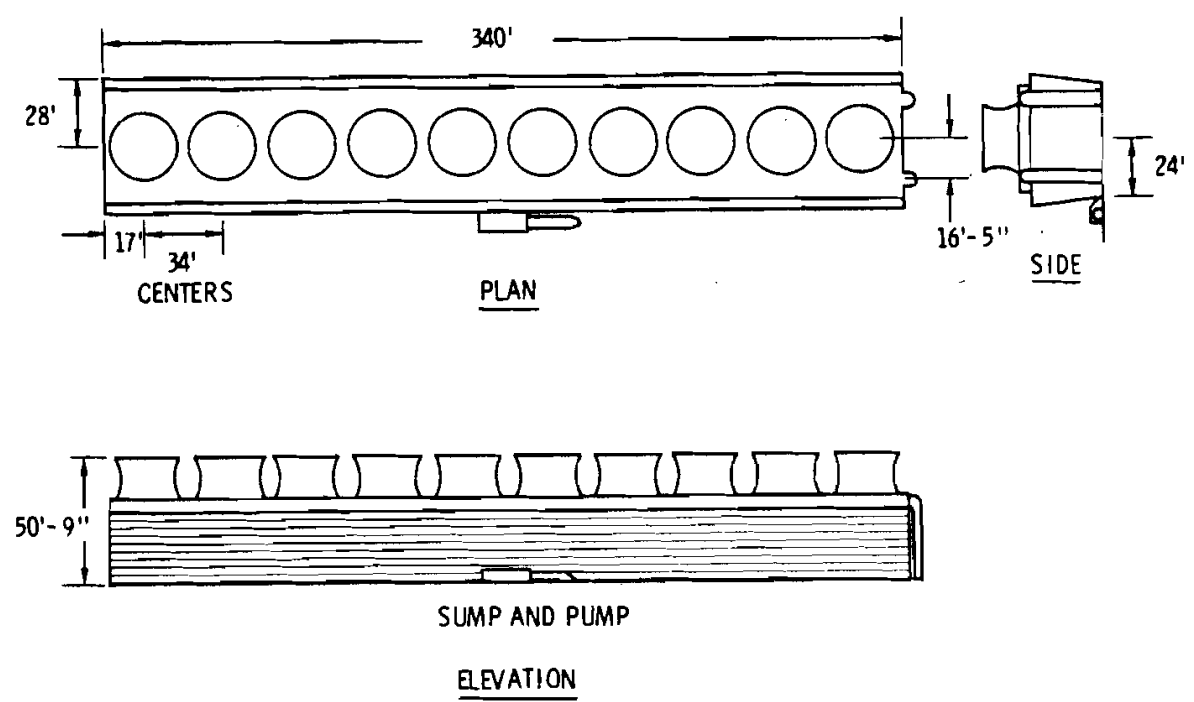

FIGURE 4-6. Wet Cooling Tower Arrangement

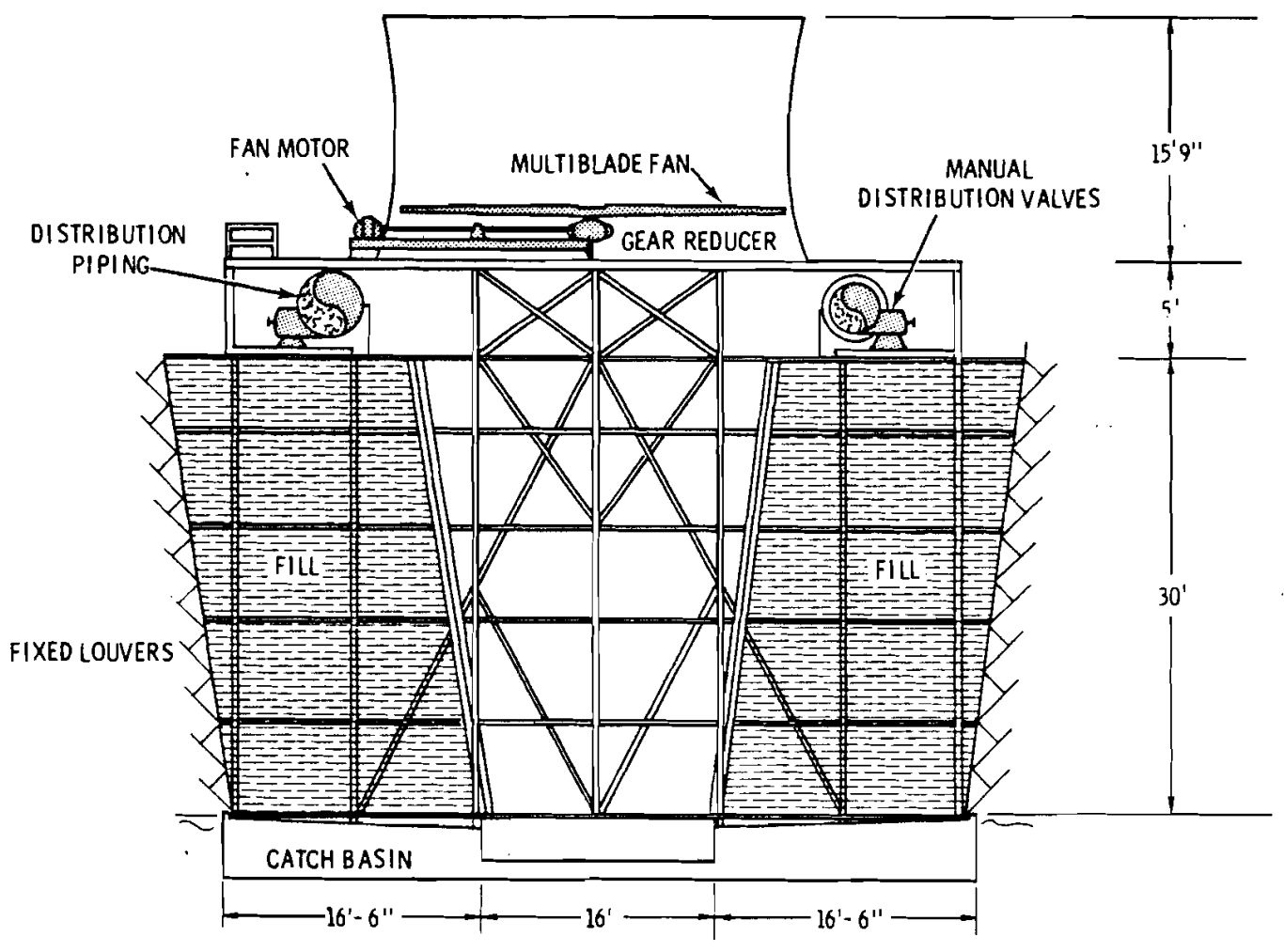

FIGURE 4-7. Wet Cooling Tower Cross Section 
The wet tower is composed of ten sections arranged end-to-end. A summary of design parameters is given in Table 4-7.

\section{TABLE 4-7. Wet Tower Design Parameters}

Type:

Wet Tower Design Temperature:

Total Air Pressure Drop:

Unit Air Flow Rate:

Unit Water Flow Rate:

Total Air Flow Rate:

Total Water Flow Rate:

Design ITD:

Frontal Area of Wet Tower:

Fi11 Cross-Sectional Area:

Number of Wet sections:
Packed tower

$95^{\circ} \mathrm{F}$

0.74 in. $\mathrm{H}_{2} \mathrm{O}$

$1580 \mathrm{lb} / \mathrm{hr}^{2} / \mathrm{ft}^{2}$ (based on frontal area)

$4800 \mathrm{lb} / \mathrm{hr} / \mathrm{ft}^{2}$ (based on fill crosssectional area perpendicular to flow)

$3.22 \times 10^{7} \mathrm{lb} / \mathrm{hr}$

$4.97 \times 10^{7} \mathrm{lb} / \mathrm{hr}$

$29.68^{\circ} \mathrm{F}$

$20,400 \mathrm{ft}^{2}$

$10,880 \mathrm{ft}^{2}$

10

\subsubsection{Wet Cooling Tower Fill}

Splash bar packing for the wet tower is shown in Figure 4-8. Splash bars are wood and have the 2 in. $x 3 / 8$ in. cross-sectional dimensions. Other specifications are provided in Table 4-8.

\section{TABLE 4-8. Wet Cooling Tower Fill Specifications}

Fill Unit Height:

Fill Unit Length:

Fill Unit Width:

Number of Fill Units/Section:

Total Fill Volume/Section:

Air Flow Rate/Section:

Water Flow Rate/Section:

Number of Fans/Section:

Louver Orientation:

Number of Louvers/Section:

Louver Dimension:

Louver Material:
$30 \mathrm{ft}$

$34 \mathrm{ft}$

$16 \mathrm{ft}$

2

$32,640 \mathrm{ft}^{3}$

$3.22 \times 10^{6} \mathrm{lb} / \mathrm{hr}$

$4.97 \times 10^{6} \mathrm{lb} / \mathrm{hr}$

1

Horizontal, Fixed

20

$4 \mathrm{ft} \times 34 \mathrm{ft}$

Asbestos Corrugated Board (ACB) 


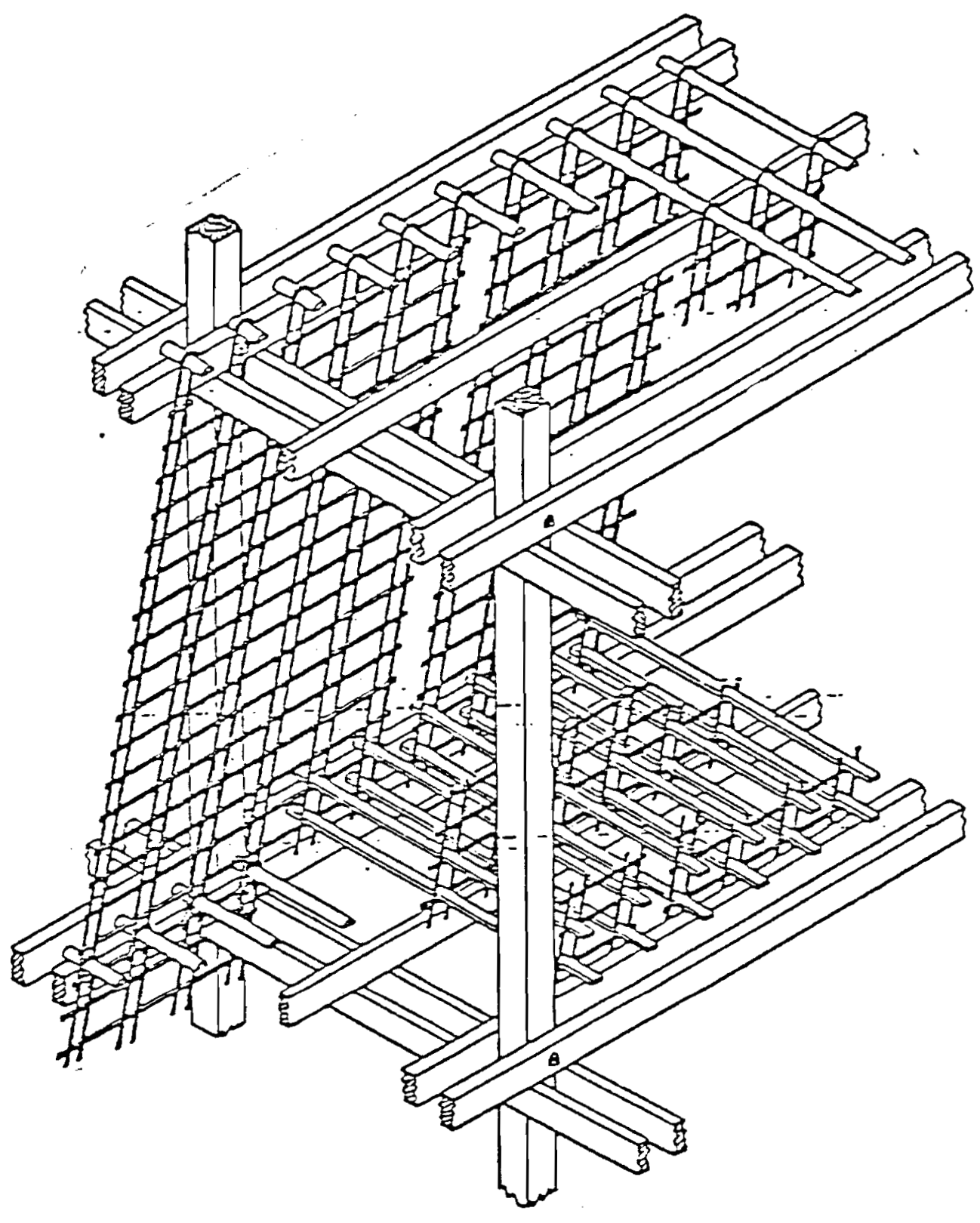

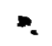

FIGURE 4-8. Packing for Wet Tower 
Drift eliminators are required for the wet tower to minimize migration of water droplets from the tower. These drift eliminators are shown in Figure 4-9.

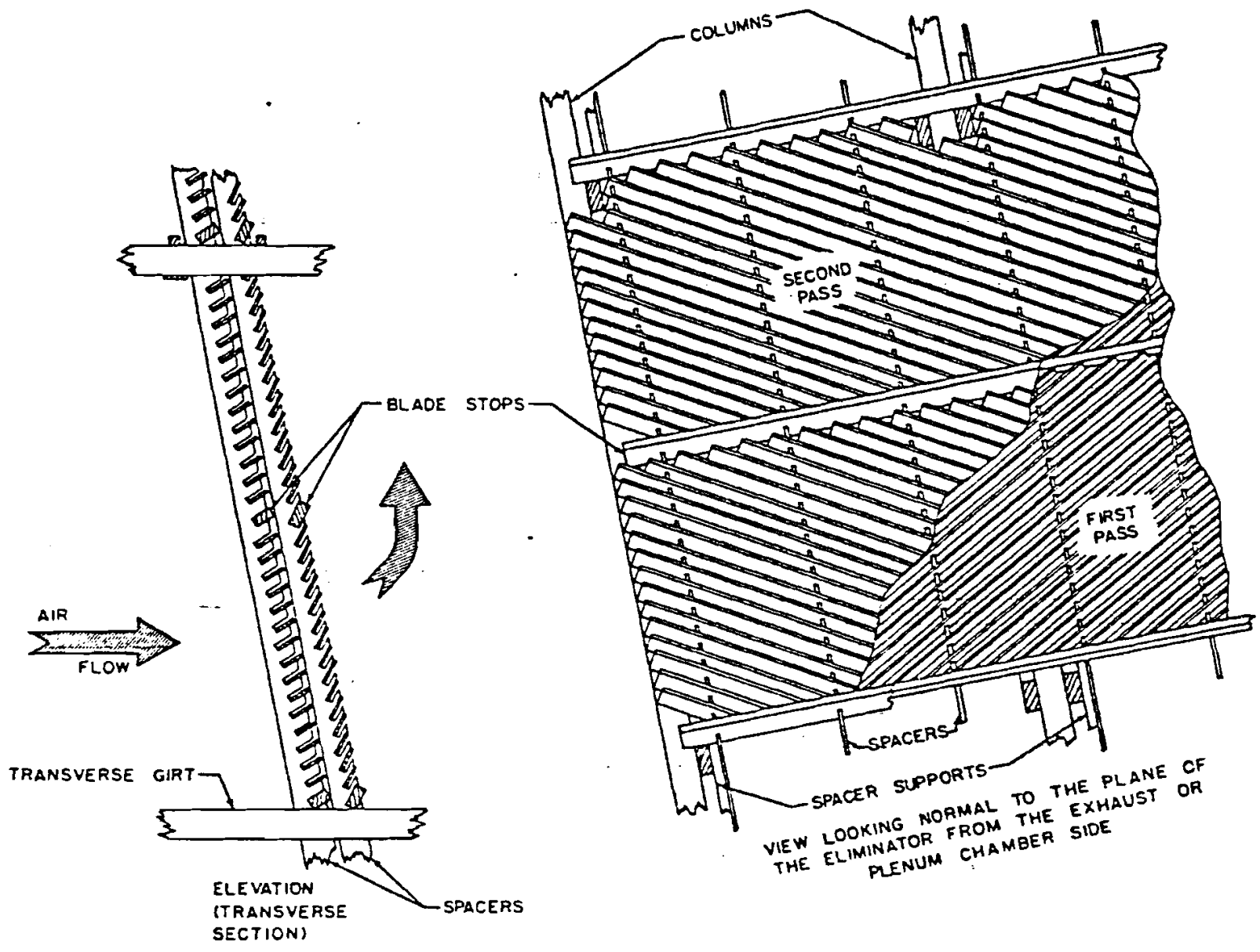

FIGURE 4-9. Drift Eliminator for wet Tower

\subsubsection{Fans}

Specifications for the fans for the dry and wet towers are provided in Table 4-9.

Louvers are specified around the entire circumference of each dry cooling tower for air control during high winds and for equalizing the air flow distribution into each A-frame. The louvers will be constructed of primed carbon steel and will rotate about the vertical axis. The face of each A-frame will be covered by louvers. Each A-frame will require twenty-eight louvers, $1 \mathrm{ft}$ wide and $24 \mathrm{ft}$ long. The louvers are arranged in two rows of 14 each, with 
one row above the other, thus covering the entire 48-ft bundle length. The louvers will be intermittently supported at $6 \mathrm{ft}$ and will be constructed of 1/16-in. thick material.

\section{TABLE 4-9. Separate Dry and Wet Tower Concept Fan Specifications}

\begin{tabular}{|c|c|c|}
\hline - & Dry Towers & Wet Tower \\
\hline Fan Diameter (ft): & 32 & 26 \\
\hline Blade Material: & Fiberglass & Fiberglass \\
\hline Number of Blades: & 12 & 8 \\
\hline Flow Rate/Fan $070^{\circ} \mathrm{F}$ (cfm): & $1,162,000$ & 716,000 \\
\hline Number of Fans/Tower: & 14 & 10 \\
\hline Number of Fans: & 42 & 10 \\
\hline hp/Fan: & 217 & 115 \\
\hline Total hp: & 9,114 & 1,150 \\
\hline Fan Packing Ratio: & 1.85 & 3.59 \\
\hline Fan Packing Arrangement: & (See Figure 4-4) & (See Figure 4-6) \\
\hline Blades: & Manually adjusted & Manually adjusted \\
\hline Motor: & Single Speed & Single Speed \\
\hline Voltage: & 480 & 480 \\
\hline Drive: & Gear train & Gear train \\
\hline Inlet Bel1: & $\begin{array}{l}5 \mathrm{ft} \text { long } \\
7.4 \mathrm{ft} \text { radius } \\
36 \mathrm{ft} \text { max. dia. } \\
\text { carbon steel }\end{array}$ & $\begin{array}{l}5 \mathrm{ft} \text { long } \\
7.4 \mathrm{ft} \text { radius } \\
30 \mathrm{ft} \text { max. dia. } \\
\text { carbon steel }\end{array}$ \\
\hline Velocity Recovery Stack: & $\begin{array}{l}18 \mathrm{ft} \text { long } \\
7^{\circ} \text { Angle } \\
\text { Fiberglass }\end{array}$ & $\begin{array}{l}18 \mathrm{ft} \text { long } \\
7^{\circ} \text { Angle } \\
\text { Fiberglass }\end{array}$ \\
\hline Total Weight (1b): & 16,200 & 12,400 \\
\hline
\end{tabular}

The louvers will be remotely controlled and adjusted through mechanical linkages. Louvers of a fixed design were specified for the wet tower. The material of construction is asbestos corrugated board (ACB). The louvers are arranged horizontally with 20 louvers per wet tower section. These louvers are shown in Figure 4-7. The louvers are $4 \mathrm{ft} \times 34 \mathrm{ft}$ and 68001 ineal $\mathrm{ft}$ of $A C B$ are required. 


\subsubsection{Water Flow System}

The piping system for the dry portion of the separate wet/dry cooling system consists of cooling water pumps, distribution piping between the condenser and heat exchanger headers (supply and return), valving, and storage tanks. A diagram of the dry cooling water piping system is provided in Figure 4-10.

The dry cooling piping system supplies cooling water to the general area of the dry towers through an 84-in. diameter buried concrete pipe. The return line is identical. During cold weather the towers can be completely bypassed with a 42-in. tie-in between the supply and return concrete lines, to allow preheating of the cooling water. At the tower end of the 84-in. line, the flow is separated into three 48-in. lines, one for each dry cooling tower. At the entrance to the cooling towers, the 48-in. 1ines are divided into four 24-in. 1ines, one for each tower quadrant. Each 24-in. line splits into two 20-in. 1ines, each supplying eight heat exchanger bundles, or onehalf a tower quadrant. The 20-in. lines supply water to two bundles each. The 20-in. lines are then reduced to 18-in. lines to supply the next two bundles on either half of the quadrant. A 16-in. line supplies the next two bundles, and a 10-in. line feeds the remaining two bundles. Both supply and return lines are at ground level, because the heat exchangers are two-pass.

The sump tank is located in the dry cooling water piping circuit to allow for expansion during circulation. A storage tank, located in the 42in. tie-in between the concrete lines, is used for drain and storage of dry tower water and has a capacity of $35,000 \mathrm{ft}^{3}$. A fili pump is provided to fill the dry towers from the storage tank.

A nitrogen cover gas system will be used to protect the carbon steel heat exchanger tubes and tower piping during shutdown periods. Approximately $35,000 \mathrm{ft}^{3}$ of nitrogen is required as an inventory at $20 \mathrm{psia}$; the nitrogen inventory is to be supplied from the nitrogen tube bank trailer. During shutdown the cover gas occupies all heat exchanger bundles, tower quadrant piping, and excess storage tank volume. Cover gas will not be provided for the $84-i n$. diameter concrete 1 ines or the 48-in. tower lines. During operation the cover gas is stored in the dry tower storage tank. 


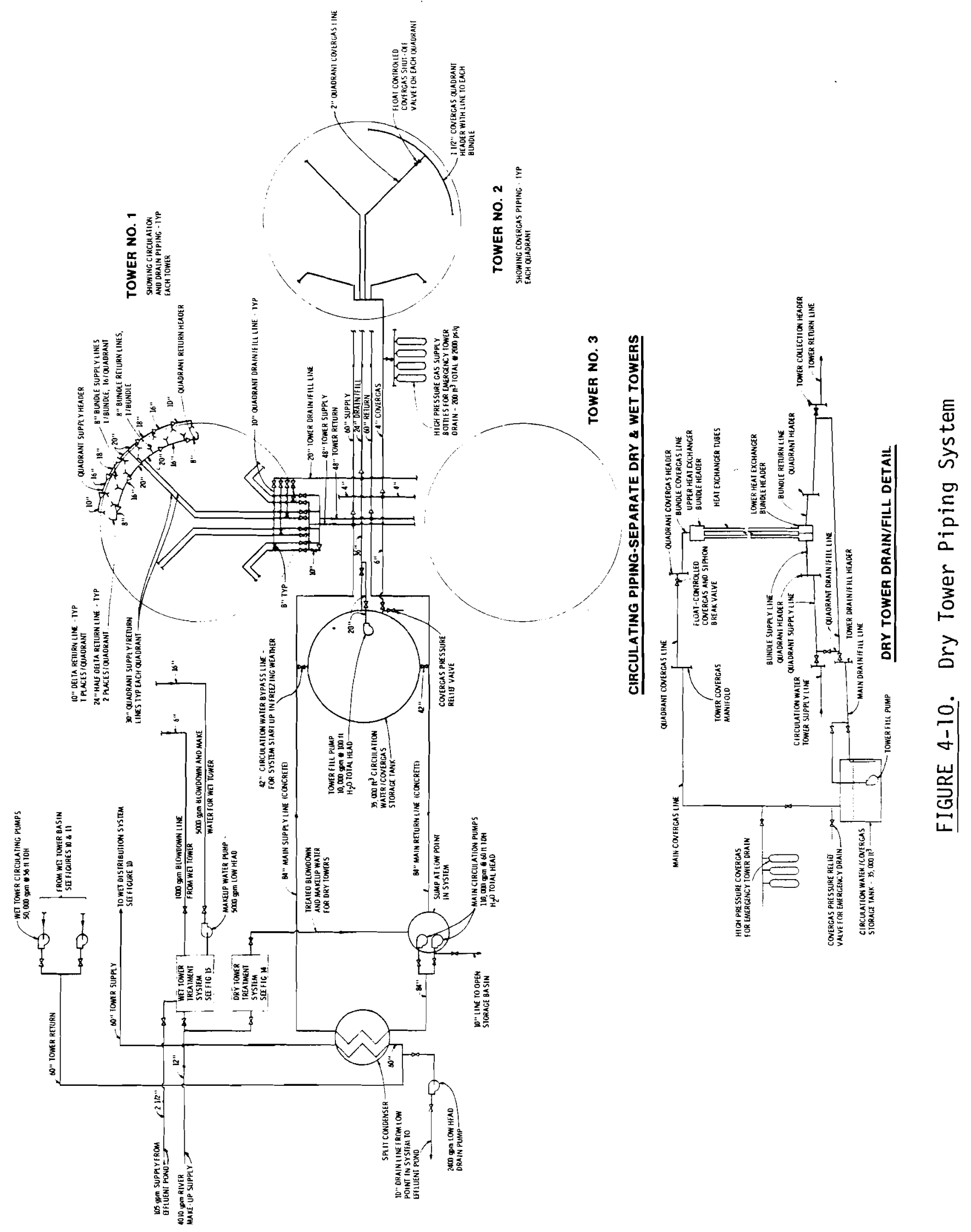


The piping system for the wet section of the separate wet/dry design is completely independent of the dry tower piping and consists of cooling water pumps, distribution piping between the condenser and the wet tower sections (supply and return), elbows and tees, reducers, valves and a collection basin. The wet cooling piping system is illustrated in Figure 4-11.

Cooling water is supplied to the wet tower through a 60 -in. diameter concrete pipe (buried) approximately $1400 \mathrm{ft}$ long. At the wet tower, the water in this 60-in. supply line can be diverted through a 40-in. 1ine directly to the collection basin below the wet tower without passing through the tower fill. Under operating conditions, the 60-in. supply line splits into two parallel 48-in. lines at the tower, one for each side of the wet sections (see Figure 4-11). The 48-in. lines provide water for the first three wet sections, after which they are reduced to 36-in. lines. The 36-in. 1 ines provide water for two additional wet sections. These lines are again reduced to 30-in. 1 ines which supply the next three wet sections, after which they are reduced to $20-i n$. lines for the final two tower sections. All distribution piping for the wet tower is positioned on top of the fill supports, just under the fan deck. Each wet section can be isolated by handoperated valves for maintenance purposes or reduced wet tower duty.

All water passing through the wet tower flows into a collection basin at the base of the tower. The volume of this basin is approximately $35,000 \mathrm{ft}^{3}$. Water to be returned to the wet side of the condenser is removed from the basin with two 50,000-gpm sump pumps feeding a buried 60-in. 1ine.

The dry tower recirculating water system is a closed system and requires water treatment at the beginning of plant operation and for makeup due to losses. A deionization treatment system will be required for the dry tower water to achieve a calcium hardness less than $30 \mathrm{ppm}$ as $\mathrm{CaCO}_{3}$ and total dissolved solids less than $100 \mathrm{ppm}$. Water for the system inventory is obtained from the San Juan River. After passing through the deionization system, the water is deoxygenated using a steam jet ejector (vacuum deaeration). Once the oxygen has been removed, a corrosion inhibitor is added to the water from a day tank. The corrosion inhibitor consists of a solution of 85 percent sodium nitrite $\left(\mathrm{NaNO}_{2}\right)$ and 15 percent sodium metasilicate $\left(\mathrm{NaSiO}_{3}\right)$. 


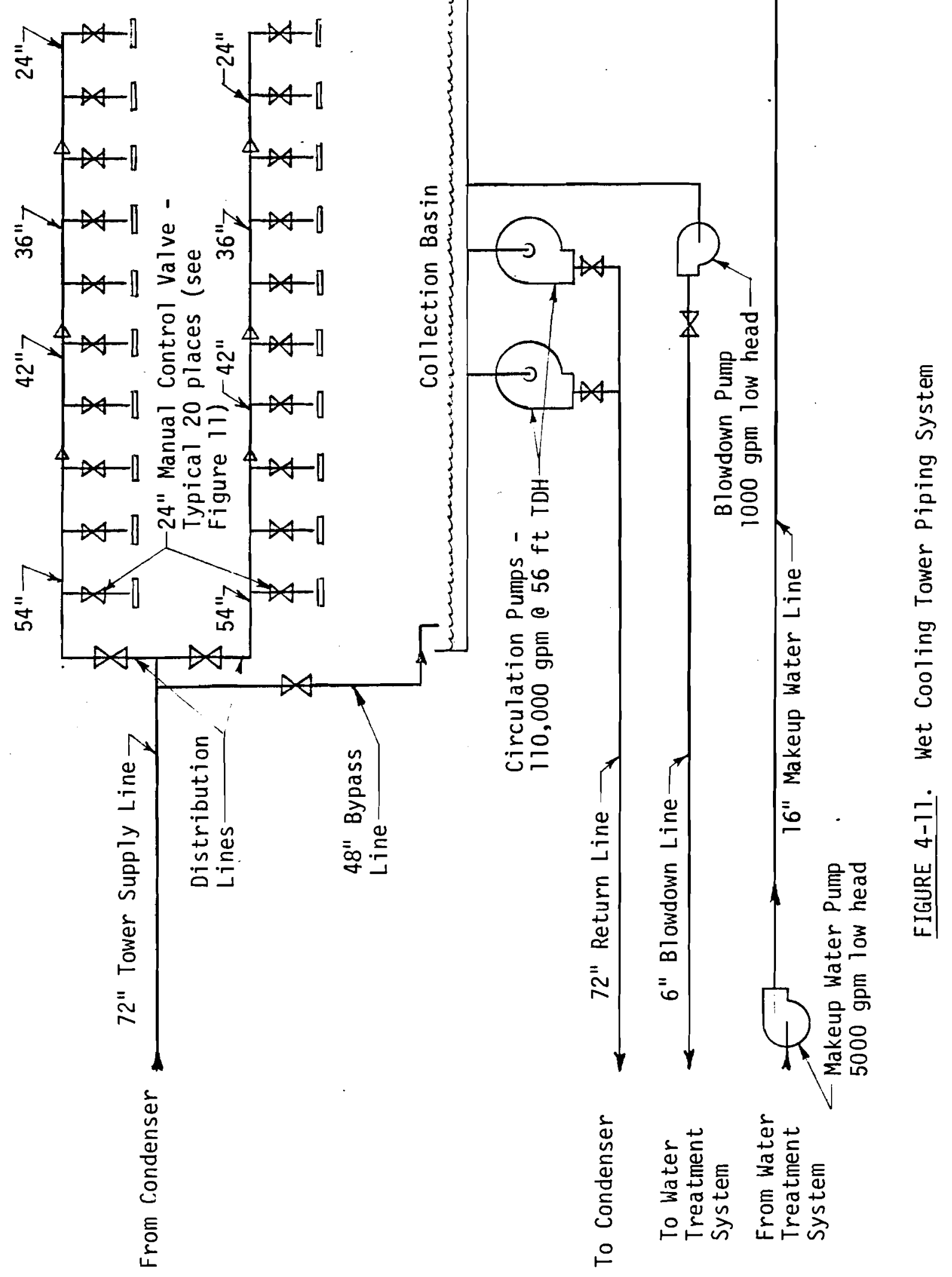


Approximately 18,820 1b of these chemicals are required to obtain a dose rate of $800 \mathrm{ppm} \mathrm{N} \mathrm{N}_{2}^{-}$(nitrite) for inhibition in the original water inventory. In addition to the inhibitor, sulfuric acid is added to the water to obtain a pH of 8.5. A plant capacity of $10 \mathrm{gpm}$ will be required.

The wet tower recirculating system is an open system. The nature of the water treatment and treatment plant capacity selected was the same as for the integrated dry/wet concept.

\subsubsection{Condenser}

The steam condenser utilizes two separate noncommunicating water-side flow circuits, one for the closed recirculating system supplying the dry tower and the other for the open system supplying the wet tower. The side associated with the dry tower was designed to handle 100 percent of the heat load at $35^{\circ} \mathrm{F}$ and $4.5 \mathrm{in}$. $\mathrm{Hg}$. back pressure; the side associated with the wet tower was designed to handle 70 percent at $95^{\circ} \mathrm{F}$ and $4.5 \mathrm{in}$. $\mathrm{Hg}$.

Specifications for this condenser are summarized in Table 4-10.

\subsubsection{Control and Instrumentation}

Control and instrumentation systems designed for this concept were almost identical to those previously described for the integrated dry/wet tower concept.

\subsection{METAL FIN-TUBE/DELUGE WATER AUGMENTATION}

\subsubsection{General Description}

This dry/wet heat rejection concept is an indirect type and utilizes a closed recirculation system to transfer the heat of condensation from the surface condenser to fin-tube heat exchangers in the cooling towers. At high ambient temperatures, the normally dry exterior surface of the heat exchanger is deluged with water to augment heat dissipation through evaporation of the delugate. 
TABLE 4-10 Condenser Specifications for Separate Dry/Wet Concept

\begin{tabular}{|c|c|c|}
\hline & Wet Side & Dry Side \\
\hline Design Air Temperature $\left({ }^{\circ} \mathrm{F}\right)$ & 95 & 35 \\
\hline Design ITD $\left({ }^{\circ} \mathrm{F}\right)$ & & 89.68 \\
\hline Design TTD $\left({ }^{\circ} \mathrm{F}\right)$ & 5.0 & 5.0 \\
\hline Design Heat Load $(B t u / h r)$ & $1.76 \times 10^{9}$ & $2.514 \times 10^{9}$ \\
\hline Water Range $\left({ }^{\circ} \mathrm{F}\right)$ & 35 & 23.1 \\
\hline Design Back pressure (in. Hg.) & 4.5 & 4.5 \\
\hline Tube Diameter (in.) & 1.0 & 1.0 \\
\hline Tube Gauge (BWG) & 20 & 20 \\
\hline Tube Material & Admiralty & Admiralty \\
\hline Air Removal Section & Stainless steel & Stainless steel \\
\hline Water Temperature In $\left({ }^{\circ} \mathrm{F}\right)$ & 89.68 & 101.58 \\
\hline Water Temperature Out $\left({ }^{\circ} \mathrm{F}\right)$ & 124.68 & 124.68 \\
\hline LMTD $\left({ }^{\circ} \mathrm{F}\right)$ & 16.8 & 13.38 \\
\hline Water Flow Velocity $(\mathrm{ft} / \mathrm{sec})$ & 5.0 & 5.0 \\
\hline Water Flow Area $\left(\mathrm{ft}^{2}\right)$ & 44.56 & 97.54 \\
\hline Water Flow Rate (gpm) & 100,000 & 219,000 \\
\hline Number of Tubes/Pass & 9,441 & 20,677 \\
\hline Total Number of Tubes & 18,882 & 20,677 \\
\hline $\begin{array}{l}\text { Heat Transfer Coefficient } \\
\qquad\left(B t u / h r-f t^{2}-{ }^{\circ} \mathrm{F}\right)\end{array}$ & 635 & 650 \\
\hline Required Surface Area $\left(\mathrm{ft}^{2}\right)$ & 163,160 & 289,070 \\
\hline Tube Length/Pass (ft) & 33.0 & 53.4 \\
\hline $\begin{array}{l}\text { Estimated Water Pressure Drop } \\
\qquad\left(\mathrm{ft} \text { of } \mathrm{H}_{2} \mathrm{O}\right)\end{array}$ & 10.7 & 9.5 \\
\hline
\end{tabular}

The cooling towers are circular in geometry and house the heat exchange surface. The heat exchanger is composed of vertically-oriented spiral finned tubes. Heat is transferred from the cooling water to the air stream passing over the outside heat exchange surfaces, and the cooled water is then returned to the surface condenser. The cooling tower is designed to operate as a 
completely dry system during the cooler periods of the year. When the air temperatures are sufficiently high, a portion of the heat exchange surface is deluged with water on the outside of the finned tubes to increase heat rejection capability. In this way, sensible heating of the air is augmented by heat transfer to the air through evaporation of the deluge water.

Each circular cooling tower is capable of handling 25 percent of the heat load. The four cooling towers are located between north coordinates $2,112,800$ and $2,113,500$ and east coordinates 322,000 and 322,700 , as shown on the site plan of Figure 4-12. The spacing between towers is a minimum of 120 feet.

\subsubsection{Cooling Tower Parameters}

The design of the metal fin-tube water augmentation cooling tower concept is shown in Figure $4-13$.

Each tower can be operated all-dry, all-wet, or a fraction thereof. The air flow through each tower is induced mechanically with seventeen 28-ft diameter fans mounted at the top of the tower structure. The heat exchanger units (groups of 160 tubes/unit) are arranged in A-frames. Augmentation water is distributed such that the tubes are deluged and sprayed simultaneously. Protection for the heat exchange surfaces is provided by louvers around the circumference of each tower. Specific information on the cooling tower system design is provided in Table 4-11.

This cooling system is designed so that all the heat load from the power plant can be rejected at ambient temperatures of $55^{\circ} \mathrm{F}$ or below. Above $55^{\circ} \mathrm{F}$, sections of the tower(s) must be augmented (deluged) to meet load.

\subsubsection{Heat Exchangers}

Each cooling tower utilizes 64 heat exchanger units illustrated in Figure 4-14. Each unit contains 160 tubes with 3 rows deep $(54,52,54)$. The tubes are staggered on an equilateral pitch with a transverse pitch of $2.625 \mathrm{in}$. The tubes are arranged for two-pass, with the appropriate header design. Each unit is preassembled with a 24 in. $x 3$ in. $\times 3 / 8$ in. channel on each edge. The units are approximately $48 \mathrm{ft}$ long on the inside and $491 / 2 \mathrm{ft}$ long overal1. The units are arranged in A-frames in the tower, with an apex angle of $60^{\circ}$. Specifications for these heat exchangers and associated louvers are given in Table 4-12. 


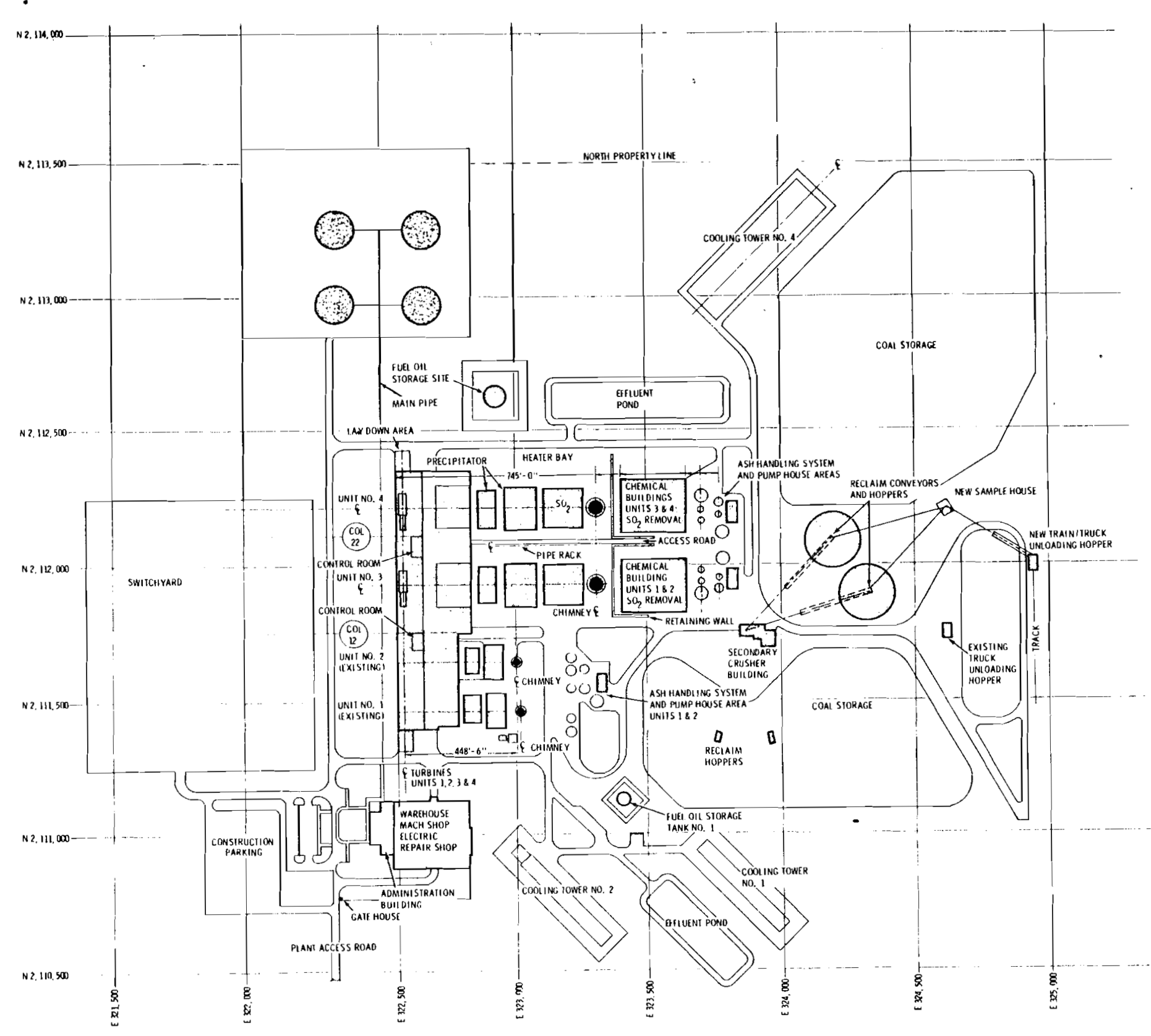

FIGURE 4-12. Site Plan for Metal Fin-Tube/Deluge Concept 

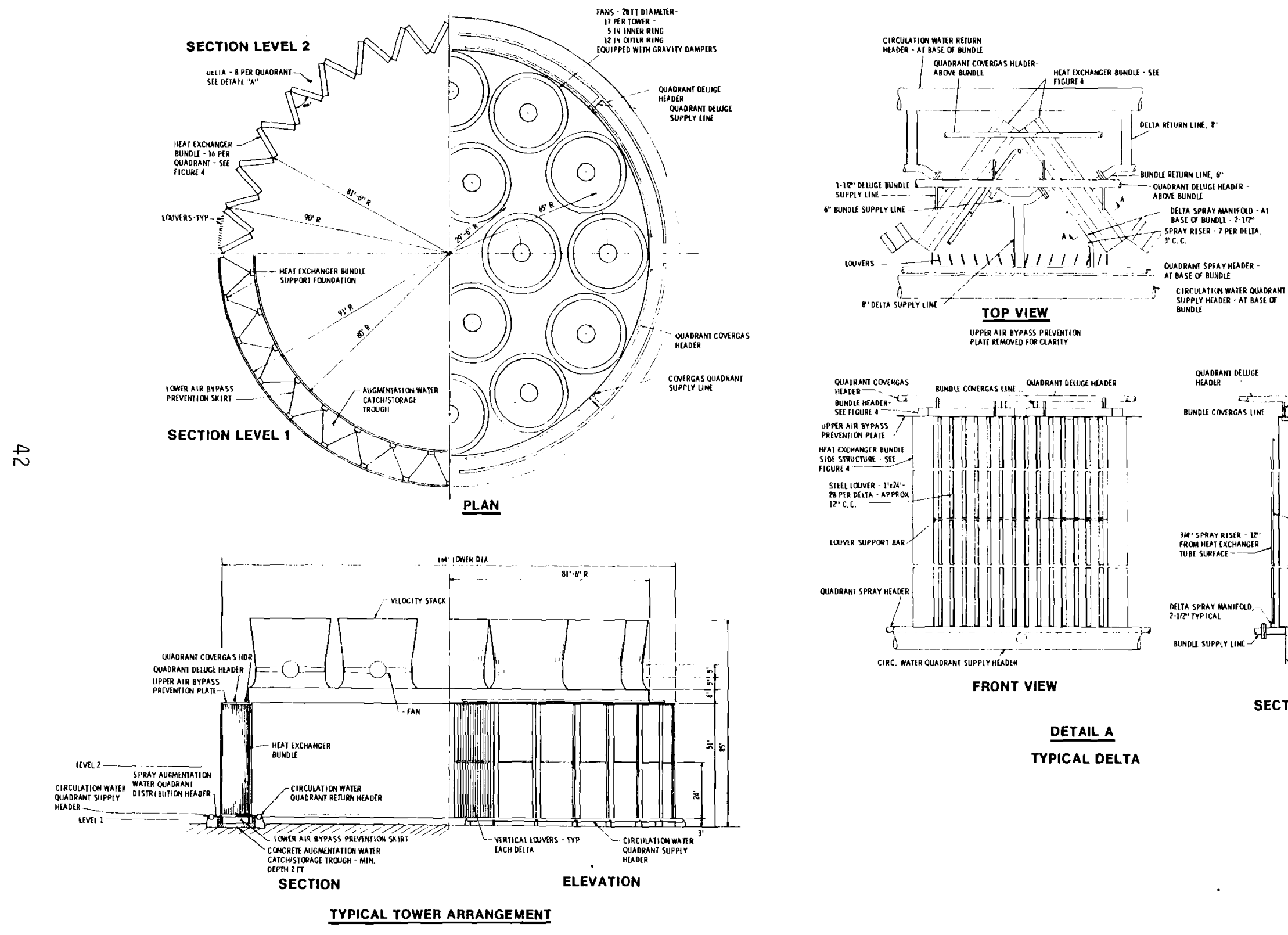

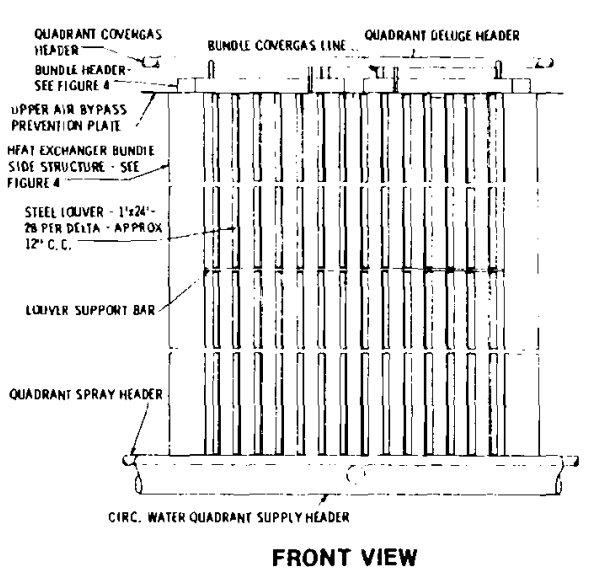

Detall A

TYPICAL DELTA

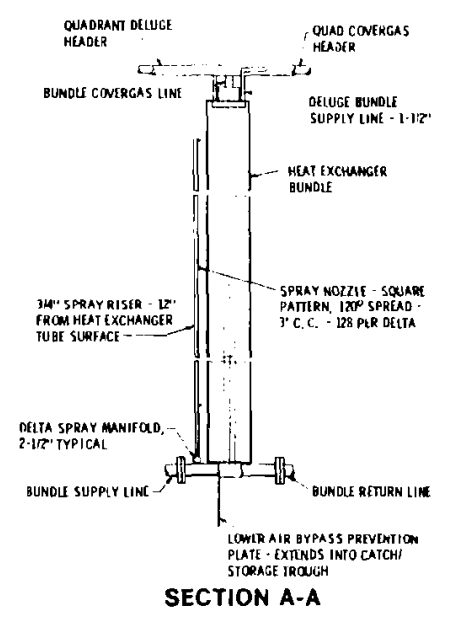

SECTION A-A

\section{FIGURE 4-13. Metal Fin-Tube/Deluge Tower Arrangement}


TABLE 4-11. Design Information for Metal Fin-Tube/ Deluge Augmentation Concept
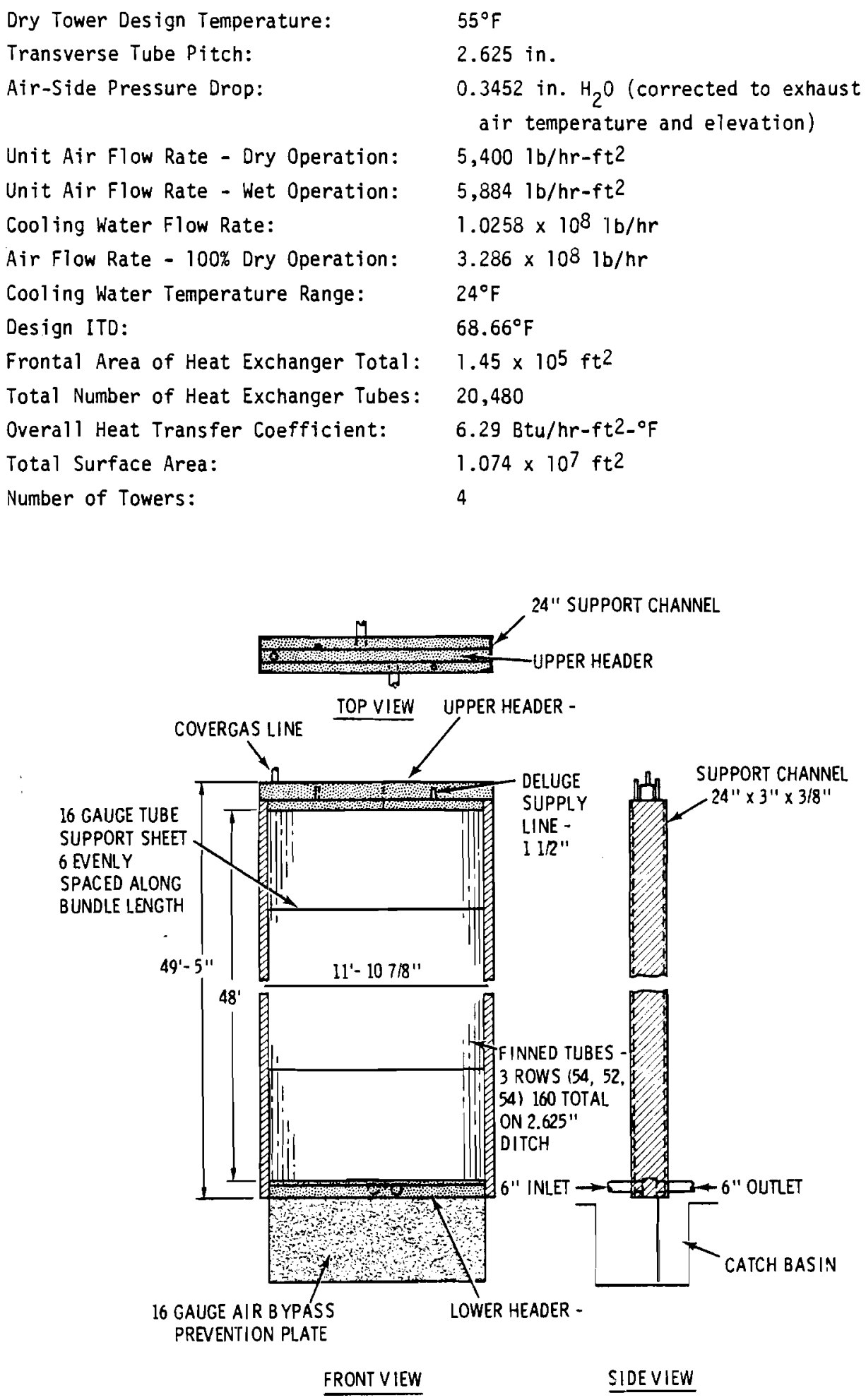

FIGURE 4-14. Metal Fin-Tube/Deluge Heat Exchanger Unit 


\section{TABLE 4-12. Heat Exchanger Specifications for Metal}

Fin-Tube/ Deluge Augmentation Concept

Type Tubes:

Materials:

Tube OD:

Tube ID:

Pitch:

Fin OD:

Fin Thickness:

Fin Spacing:

Width of One Bundle:

Depth of One Bundle:

Length of One Bundle:

Tube Geometry:

Number of Units/A-Frame:

Number of A-Frames/Tower:

Number of A-Frames/Tower Quadrant: 8

Air Flow Rate/Tower:

Cooling Water Flow Rate/Tower:
$2.32 \times 10^{7} \mathrm{cfm}$

Extruded spiral fin

Aluminum fins;

carbon steel tubes

$1.070 \mathrm{in.}$

0.93 in.

10 fins/in.

$2.25 \mathrm{in}$.

0.018 in.

0.082 in.

$11 \mathrm{ft} .-10-7 / 8$ in.

10 in.

$49 \mathrm{ft}-6$ in.

Staggered, equilateral, traverse pitch 2.625 in.

2

32

$2.565 \times 10^{7} \mathrm{lb} / \mathrm{hr}$

Delugeate is supplied by two separate methods. The primary method utilizes a trough and scupper configuration to flow $0.2 \mathrm{gpm}$ of water on the OD of each heat exchanger fin tube. This method is pictured in Figure 4-15. Water is also applied to the upstream (air) side of the heat exchanger spray nozzles. Each adjacent pair of heat exchangers is supplied by 128 spray nozzles spaced on a 3 -ft square matrix. Approximately $0.3 \mathrm{gpm} / \mathrm{tube}$ is supplied by the spray system.

The deluge flow down the fins provides a solid water film to prevent corrosion and deposition on the extended surfaces. The spray provides the surface area required for adequate evaporation. 


\section{DELUGE INJECTION TROUGH DETAIL}

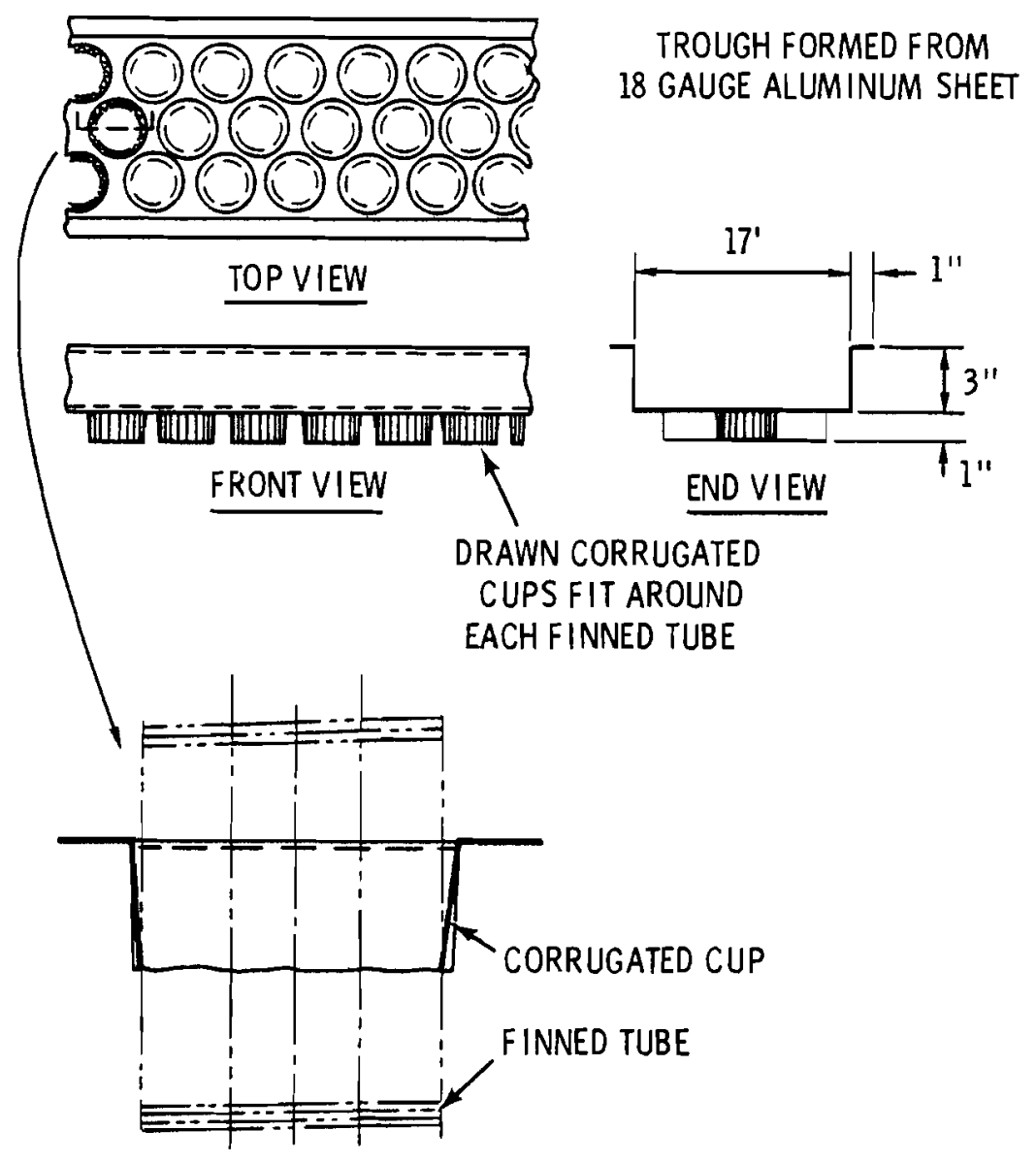

FIGURE 4-15. Method of Applying Delugeate

Each bundle has a dry weight of approximately 15,300 $\mathrm{lb}$, a weight with circulation water but without deluge water of approximately $18,300 \mathrm{lb}$, and a weight including both circulation and deluge water of approximately 28,600 1b.

\subsubsection{Fans}

Specifications for the fans used in the dry/wet cooling tower concept are given in Table 4-13.

Louvers will be required around the entire circumference of each cooling tower for air flow control during high winds and for equalizing the flow distribution into each A-frame. The louvers will be constructed of primed 
carbon steel and will rotate about the vertical axis. The face of each A-frame will be covered by louvers. For each A-frame, 28 louvers one $\mathrm{ft}$ wide by $24 \mathrm{ft}$ long will be required. These louvers are arranged in two rows of 14 each, with one row above the other, thus covering the entire bundle length of $48 \mathrm{ft}$. The louvers will be intermittently supported at $6.0 \mathrm{ft}$ and will be constructed of 1/16-in. material.

TABLE 4-13. Fan Specifications for Metal Fin-Tube/Deluge Augmentation Cooling Tower Concept

Fan Diameter:

Blade Material:

Number of Blades:

Blade Angle:

Fan rpm:

Flow Rate/Fan:

Total Pressure:

hp/Fan:

Inlet Bel1:

Velocity Recovery Stack:

Material:

Number of Fans/Tower:

Total Number of Fans:

Fan Packing Ratio:

Fan Packing Arrangement:

Blades:

Single Speed AC Motor (480 V)

Drive:

Weight of Fan Assemb?y, including stack:
$28 \mathrm{ft}$

Fiberglass

6

$16^{\circ}$

136

$1,364,000 \mathrm{cfm}$ at $90^{\circ} \mathrm{F}$

0.54 in. $\mathrm{H}_{2} \mathrm{O}$

$110 \mathrm{hp}$

$5 \mathrm{ft}$ long, $6.9 \mathrm{ft}$ radius, $\max$. dia. $=31.5 \mathrm{ft}$

$18 \mathrm{ft}$ long, $7^{\circ}$ angle

Fiberglass for stack;

Carbon steel for bell

17

68

2.0

See Figure 4-13

Manually Adjusted

Gear Train

$12,5001 \mathrm{~b}$ 
The louvers will be remotely controlled and adjusted through mechanical linkages.

\subsubsection{Water Flow Systems}

The recirculating system for the deluge cooling towers consists of cooling water pumps, distribution piping between the condenser and heat exchange headers (supply and return), and storage tanks.

The main piping system supplies cooling water to the general area of the cooling towers through an 84-in. diameter buried concrete pipe approximately $1000 \mathrm{ft}$ long. The return line is similar. At the tower end of the 84-in. line, the flow is first separated into two 42-in. lines and one 60-in. line. The 60-in. line is then split into two 42-in. lines for the two far towers.

At the cooling tower, the 42-in. line is divided into four 20-in. lines, one for each tower quadrant. In addition, a 10-in. crossover line with motor-aperated valve connects the tower supply and return lines. This crossover line, together with a $42-i n$. bypass 1 ine through the storage tank, permits the towers to be bypassed completely during cold weather to allow a reasonable temperature rise in the water before filling the towers. The 20-in. quadrant lines split into two 18-in. lines, each supplying eight bundles, or one-half the quadrant. The 18-in. lines supply water to four bundles each. Each 18-in. line is then reduced to 14-in. diameter to handle the next two bundles. An $8-i n$. line feeds the remaining two bundles. Along this quadrant, the entrance (and exit) pipe for each delta header is 8 -in. diameter. This 8-in. delta line splits into two 6-in. lines, one for each bundle. The return system is identical to the supply system. Both supply and return lines are at ground level, because the heat exchanger is two-pass. A sump at the cooling water pumps serves as a surge tank during system operation. A storage tank will be used for drain and storage of the towers only and will have a capacity of approximately $35,000 \mathrm{ft}^{3}$. A fill pump will be supplied for filling the towers. This recirculation flow system is illustrated in Figure 4-16. 


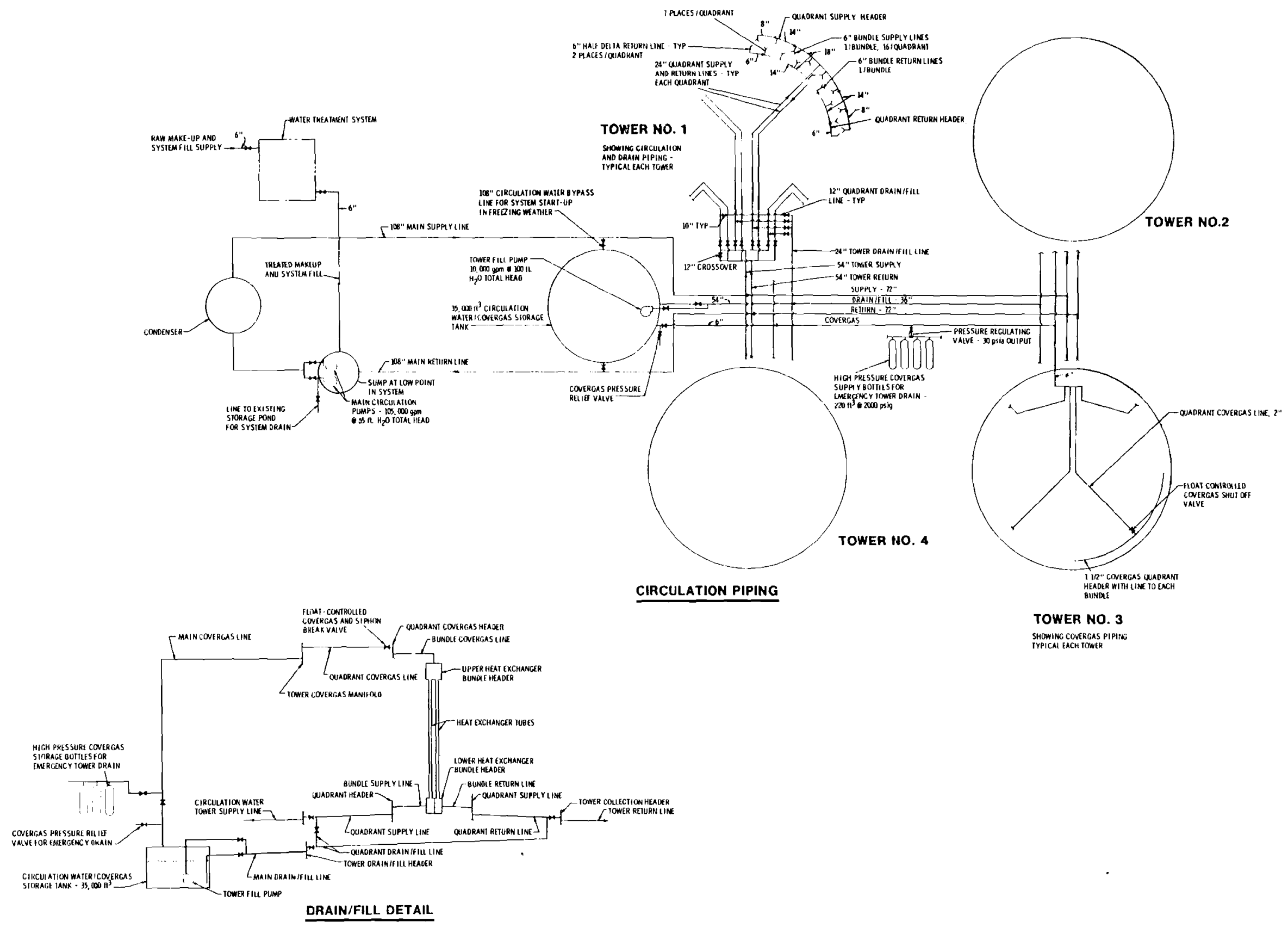


The deluge piping system is composed of four separate piping networks, one for each tower. Each deluge piping network contains:

- two deluge pumps (vertical sump)

- a deluge storage area

- distribution piping

- spray nozzles and piping

- deluge distribution channels.

Each deluge pump will have a capacity of $2700 \mathrm{gpm}$ at $88 \mathrm{ft}$ of $\mathrm{H}_{2} \mathrm{O}$ (two pumps per tower). The suction side of the vertical sump pump will be immersed in a circular concrete channel which catches all the water falling from the tube bundles. This channel serves not only as a collection basin, but also as a storage area when the tower is being operated dry. A 16-in. diameter line is connected to the pump discharge header and is then split into four 8-in. lines, one for each quadrant. Each 8 -in. line is then separated into one 4-in. line and one 6-in. line. The 4-in. line goes to the top of the quadrant headers, where it supplies water to the deluge distribution trough. The 4-in. line splits into two $3-i n$. lines, each supplying eight distribution troughs. The 6-in. line provides spray water to the nozzles. It splits into two 4-in. quadrant headers, each supplying four deltas (half the quadrant). After supplying two deltas, the $4-i n$. line is reduced to $31 / 2 \mathrm{in}$. It then supplies a third delta, after which it is reduced to $21 / 2 \mathrm{in}$. to supply the fourth delta. Water is transmitted along the base of each delta through a 2 1/2-in. line supplying seven 3/4-in. spray headers. The spray headers run vertically the total height of each bundle and have spray nozzles located on 3-ft intervals. All piping in the quadrants is constructed of polyethylene.

The control system for deluge allows the startup or shutdown of one quadrant at a time. When a quadrant is switched to wet operation, a timedelayed switch allows the tubes in the selected quadrant to be wetted with deluge prior to activation of the spray nozzles.

A side-stream water treatment plant of $10 \mathrm{gpm}$ capacity supplies the recirculation system with deionized and deaerated water. Corrosion inhibitor and acid is added to control pH (pH 8.5). The details of this water treatment are the same as described for the dry tower closed recirculation system in Section 4.2 . 
A maximum total volume of $6.15 \times 10^{8}$ gal. of water from the San Juan River is available for use in the deluge system each year. Because the system is open, no attempt will be made to deoxygenate the water. Approximately $4000 \mathrm{gpm}$ of water will be evaporated at maximum usage.

River water requiring $\mathrm{pH}$ control only will supply the required makeup water for the deluge system. Addition of sufficient sulfuric acid solution to lower the $\mathrm{pH}$ to between 7.6 and 7.8 will set the maximum allowable dissolved solids concentration level at about six cycles. At the maximum evaporation rate of $4000 \mathrm{gpm}$, a blowdown rate of $800 \mathrm{gpm}$ (200 gpm per tower) will be required to maintain the dissolved solids concentration at this leve1.

Because discharge of the blowdown is unacceptable, it will be necessary to circulate the 200-gpm blowdown from each deluge basin through a 1 ime softener treatment station to remove the dissolved solids. A flow of $85 \mathrm{gpm}$ leaves the softener as a sludge to be pumped to the effluent pond. The remaining $715 \mathrm{gpm}$ leaves the softener as softened water and is joined to a flow of $4085 \mathrm{gpm}$ of untreated river makeup water to form a stream of $4800 \mathrm{gpm}$. Before being pumped into the deluge system, $66^{\circ}$ Baume $(97 \%) \mathrm{H}_{2} \mathrm{SO}_{4}$ solution is added to this stream at a rate of $375 \mathrm{gal} / 112-\mathrm{hr}$ day to lower the $\mathrm{pH}$ to the required level for scale inhibition. It is expected that a single 4800-gpm capacity pump will be sufficient to circulate the treatment and makeup system flow.

Whenever a tower is changed from wet to dry operation, the tube surfaces should be flushed with $500 \mathrm{gpm}$ per quadrant of zero hardness water for about 5 min. Water containing less than $5 \mathrm{ppm}$ calcium as $\mathrm{CaCO}_{3}$ will be produced for all towers by passing a maximum of 30,000 gal./day of excess deluge makeup water through a sodium zeolite water softening system. The demineralized water produced by the system will then be stored in a central 30,000-gal. steel or lined concrete open storage tank. Thirty thousand gallons will allow consecutive flushing of up to 12 cooling tower quadrants. One flushing pump rated at $500 \mathrm{gpm}$ at $88 \mathrm{ft}$ of $\mathrm{H}_{2} \mathrm{O}$ will be provided to serve al1 four towers. 
$\Delta$ nitroaen cover qas svstem will be used to protect the carbon steel heat exchanger tubes and tower piping during shutdown periods. Approximately $35,000 \mathrm{ft}^{3}$ of nitrogen are required as an inventory at approximately $20 \mathrm{psia}$; the nitrogen is to be supplied from two nitrogen bottle trailers. During shutdown the cover gas occupies all heat exchanger bundles, quadrant piping (24-in. lines or less), and remaining storage tank volume. Cover gas will not be provided for the 84-in. diameter concrete piping or the steel tower supply and return pipes. During operation of the towers, the cover gas is stored in the storage tank. For emergency shutdown (for freeze protection) nitrogen is supplied to the top headers for the purpose of driving out the water quickly. In this case, the storage vessel will be vented, and the excess nitrogen will be exhausted to atmosphere. Nitrogen at 2000 psia will be required for the emergency shutdown system; regulators will be used to control the upper heat exchanger header pressure at 30 psig.

\subsubsection{Condenser}

The condenser required by this concept is identical to that specified for the San Juan Unit 3 and described in Section 4.1.

\subsubsection{Instrumentation and Control}

The tower control is accomplished by the use of a microprocesser. This microprocessor is similar to that specified for the San Juan Unit 3 except that an additional control function--louver position--is required. The microprocesser will analyze input data and take appropriate action to maintain back pressure and assure economic water use. An alarm system is provided to indicate off-standard conditions and equipment status.

\subsection{PLASTIC TUBE DELUGE WATER AUGMENTATION}

\subsubsection{General Description}

This heat rejection concept is an indirect type and utilizes a closed recirculation system to transfer the heat of turbine exhaust steam condensation from the surface condenser to polyethylene heat exchangers in the cooling towers. At high ambient temperatures, the normally dry exterior surface of the polyethylene heat exchanger tubes is deluged with water to 
augment the heat dissipation through evaporation of the delugate. The cooling towers are circular in geometry and house the heat exchange surface. The heat exchanger is composed of vertically-oriented, bare, high density polyethylene tubes. Heat is transferred from the cooling water to the air stream passing over the outside heat exchange surfaces, and the cooled water is then returned to the surface condenser.

The cooling tower is designed to operate as a completely dry system during the cooler periods of the year. When the air temperatures are sufficiently high, a portion of the heat exchange surface is deluged with water on the outside of the tubes to increase heat rejection capability. In this way, sensible heating of the air is augmented by heat transfer to the air through evaporation of the deluge water. The overall tower design is based upon the maximum use of available water for augmentation with minimum amount of heat exchange surface area.

The two cooling towers are located between north coordinates $2,113,000$ and 2,112,500 and east coordinates 322,000 and 322,800. The spacing between towers is approximately $120 \mathrm{ft}$.

\subsubsection{Cooling Tower Parameters}

- The design of the cooling towers is illustrated by the plan view, elevation and heat exchanger plan views given in Figures 4-17 and 4-18.

Each tower can be operated all-dry, all-wet or partially wet. The air flow is induced mechanically by 31 fans located in each tower. The polyethylene heat exchanger tubes are oriented vertically. During high ambient conditions these tubes are deluged with water to provide an augmented heat dissipation effect. Louvers are provided to protect the heat exchanger tubes and to control draft. Specific information on this cooling system is given in Table 4-14.

With this cooling system design, the entire heat load from the power plant can be rejected at ambient temperatures of $55^{\circ} \mathrm{F}$ or below without deluging. Above $55^{\circ} \mathrm{F}$ the towers can be deluged one quadrant at a time up to all eight quadrants to meet load. 


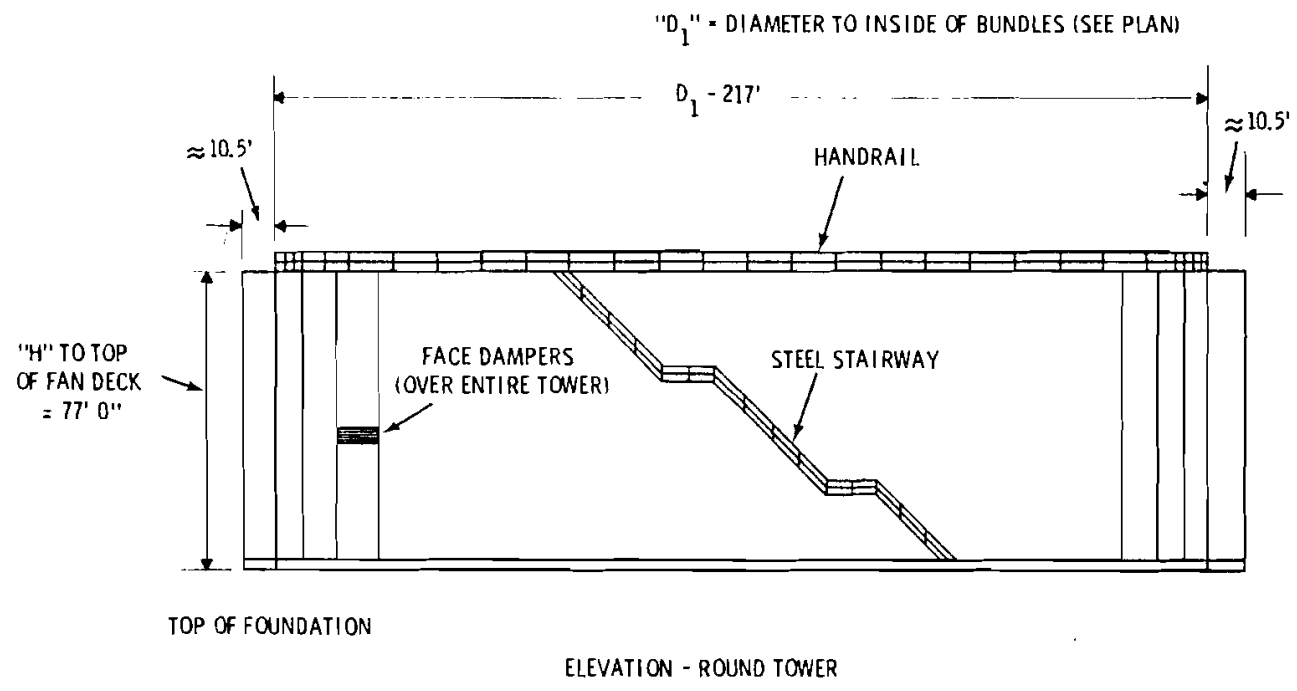

Elevation View

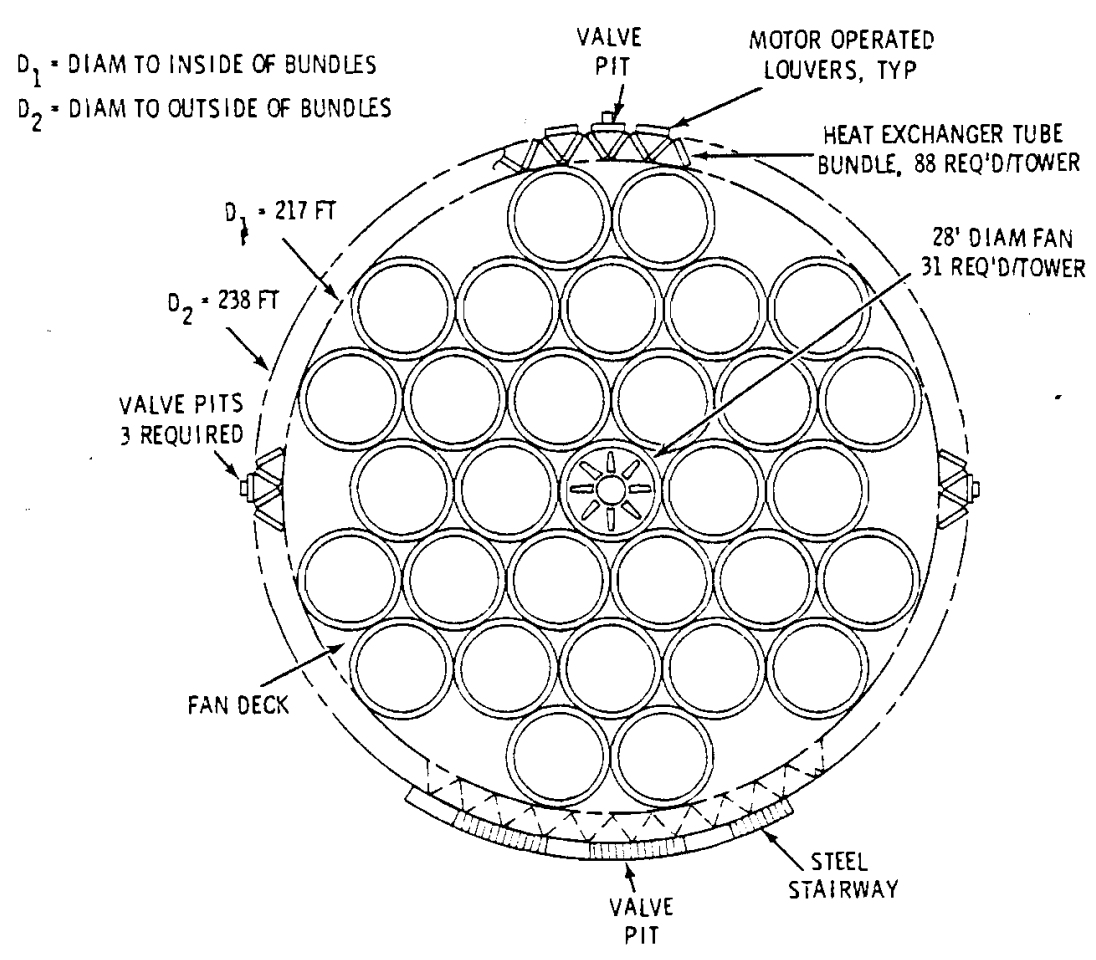

PLAN - ONE TOWER

Plann View

FIGURE 4-17. Plastic Heat Exchanger Cooling Tower 


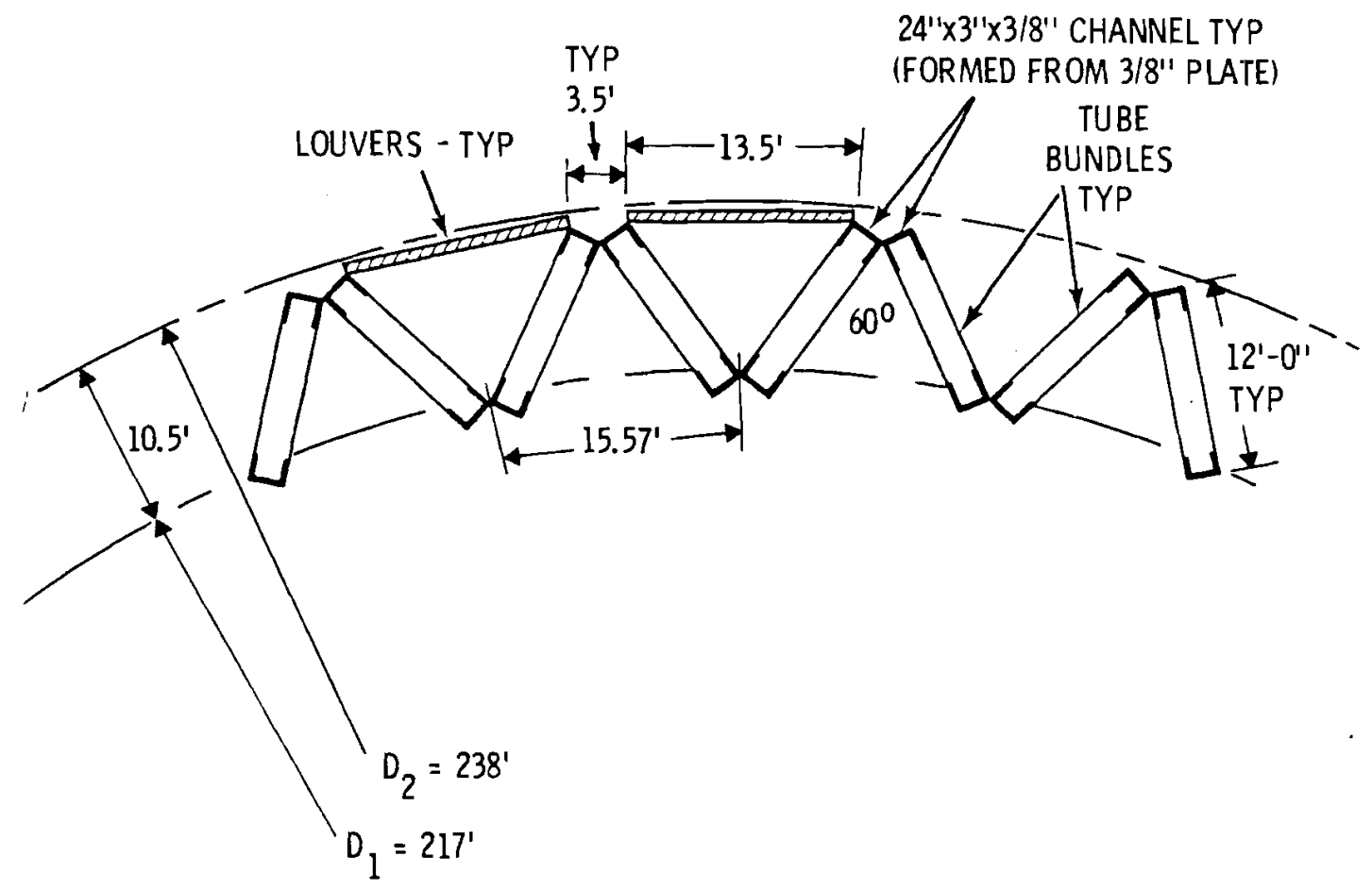

DELTA CONFIGURATION

FIGURE 4-18. Plastic Heat Exchanger Cooling Tower: Heat Exchanger Arrangement

TABLE 4-14. Plastic Heat Exchanger Deluge Augmentation Concept Design Information

Number Cooling Towers:

Dry Tower Design Temperature:

Air-Side Pressure Drop:

Air Flow Rate/Tower (Dry):

Air Flow Rate/Tower (Wet):

Cooling Water Temperature Range:

Design ITD:

Total Frontal Area of Heat

Exchangers:

Total Number of Heat Exchanger

Tubes:

Total Surface Area:
2

$55^{\circ} \mathrm{F}$

0.3348 in $\mathrm{H}_{2} \mathrm{O}$

$0.93 \times 10^{8} \mathrm{lb} / \mathrm{hr}$

$0.55 \times 10^{8} \mathrm{lb} / \mathrm{hr}$

$24^{\circ} \mathrm{F}$

$70^{\circ} \mathrm{F}$

$1.42 \times 10^{5} \mathrm{ft}^{2}$

$1,182,720$

$6.5 \times 10^{6} \mathrm{ft}^{2}$ 


\subsubsection{Heat Exchangers}

The polyethylene tube heat exchanger units are shown in Figures 4-19 and 4-20. Each unit contains 6720 tubes arranged on a staggered, equilatera1 pitch (transverse pitch $=0.60 \mathrm{in.}$ ). Tubes are arranged for two passes. The units are approximately $12 \mathrm{ft}$ wide and $70 \mathrm{ft}$ high and are placed vertically at a $60^{\circ}$ angle with adjacent units in the towers shown in Figure 4-18. There are 88 units in each tower. Specifications for these heat exchangers are given in Table 4-15.

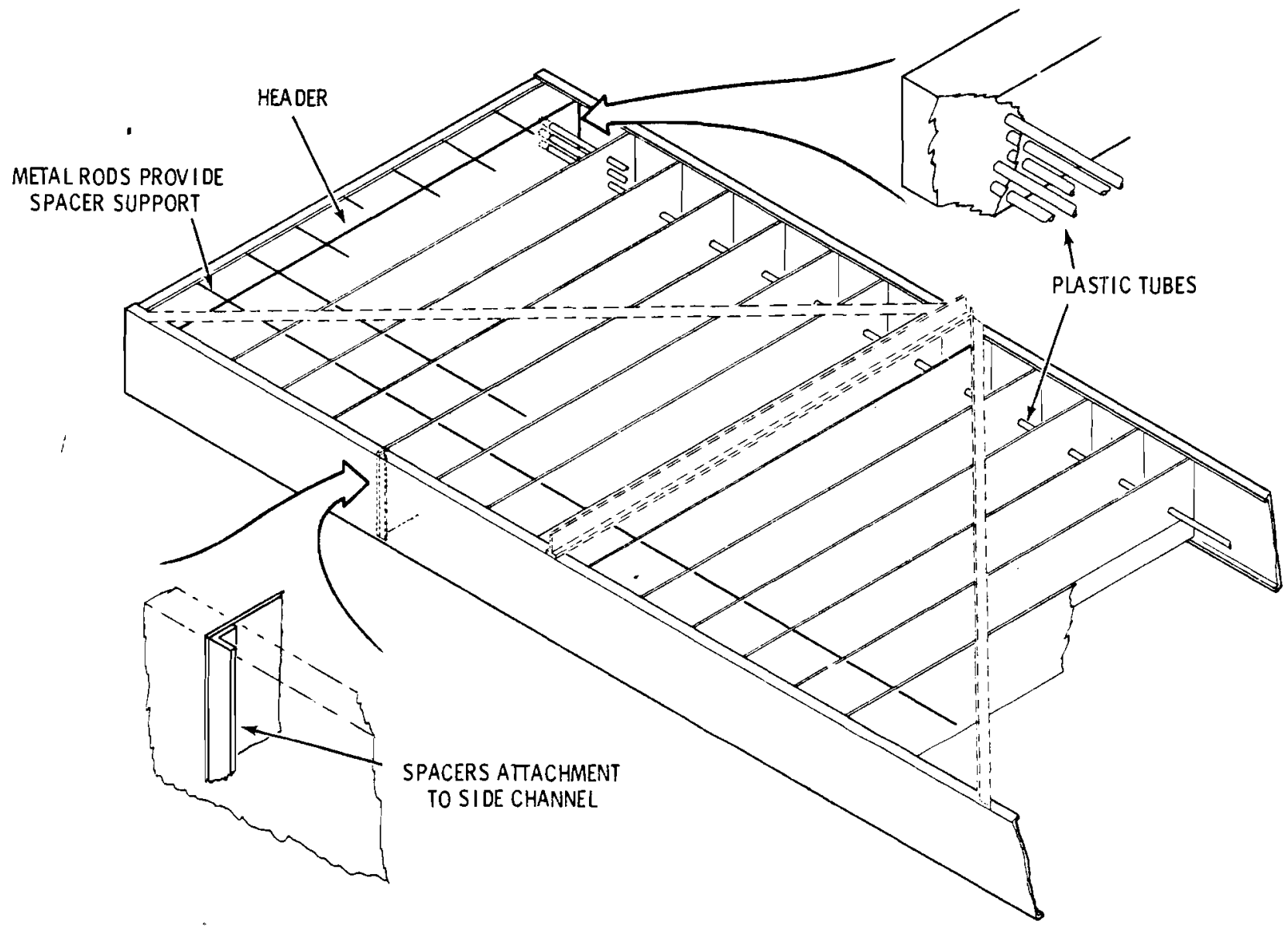

FIGURE 4-19. Plastic Tube Heat Exchanger Assembly 
TWO PASS PLASTIC TUBE BUNDLE SCHEMATIC

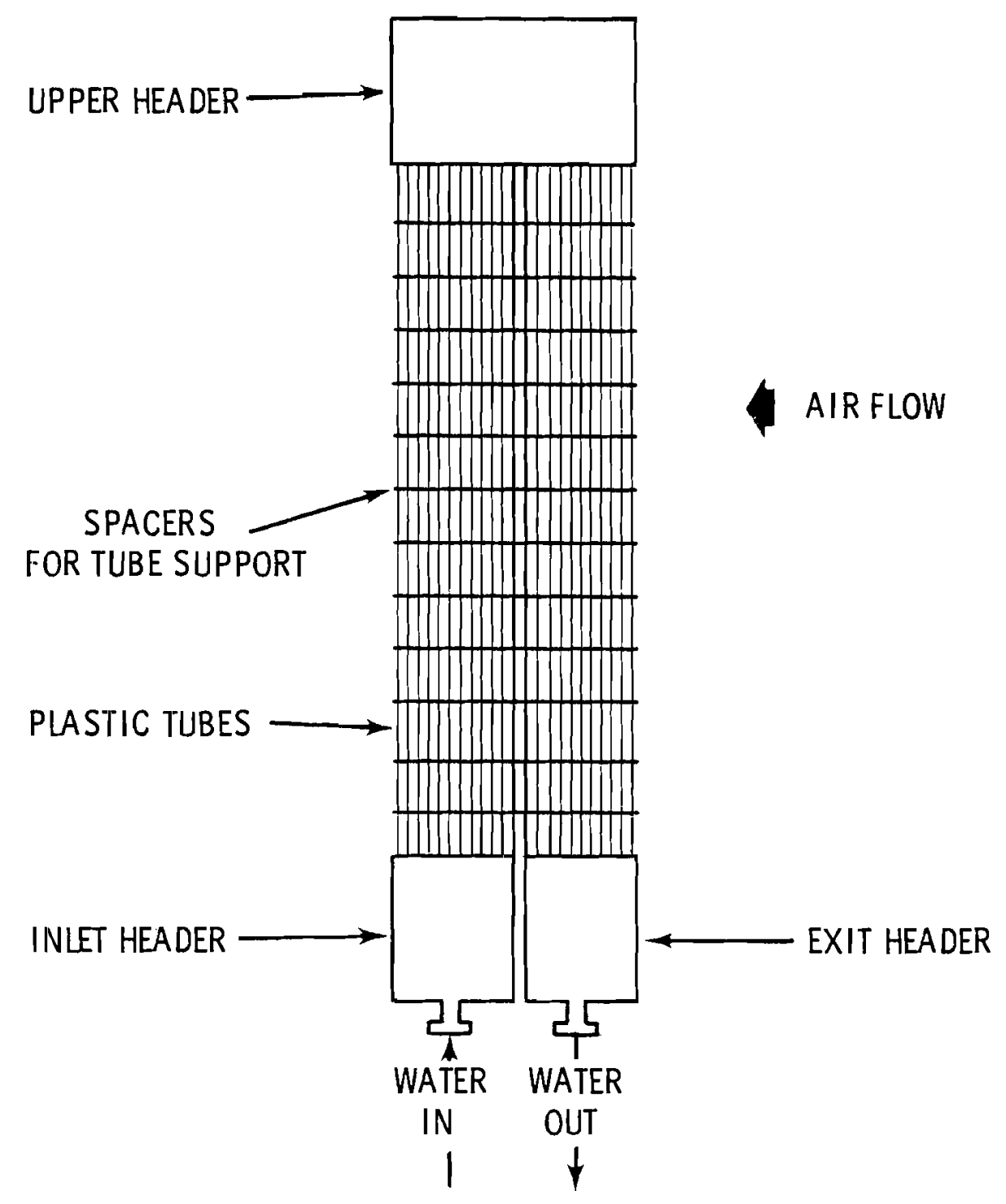

FIGURE 4-20. Plastic Tube Heat Exchanger Schematic Drawing 
TABLE 4-15. Plastic Tube Heat Exchanger Design Specifications

Material:

Tube OD:

Tube Wall Thickness:

Tube Length:

Bundle Geometry:

Transverse Pitch:

Bundle Width:

Effective Bundle Width:

Number of Tubes/Row:

Number of Passes:

Number of Rows/Pass:

Total Number of Rows:

Total Number of Tubes/

Bund le:

Water Velocity in Tubes:

Number of Bundles/Tower:
High density black polyethylene

$0.300 \mathrm{in}$.

0.030 in.

$70.0 \mathrm{ft}$

Staggered, equilateral

0.600 in.

$12.0 \mathrm{ft}$

$11.5 \mathrm{ft}$

240

2

14

28

6720

$2.49 \mathrm{ft} / \mathrm{sec}$

88

Above ambient air temperatures of $55^{\circ} \mathrm{F}$, deluge water will be applied to the plastic tubes by the arrangement pictured in Figure 4-21. Any number of tower quadrants may be deluged in accordance with demand. Even at the greatest demand, only 75 percent of the surface requires deluging. Therefore, the deluge water will be pumped to a point three-quarters of the way from the bottom of the bundle. Flow down the tube bundle is redistributed at $11 / 2-\mathrm{ft}$ intervals by the tube bundle spacers. A catch basin below the bundles collects the water remaining after evaporation. The average flow rate of delugeate per tube is approximately $0.017 \mathrm{gpm}$.

\subsubsection{Fans}

Specifications for the fans used in the cooling towers are given in Table 4-16. 


\section{SPACER ASSISTED DELUGEATE REDISTRIBUTION}

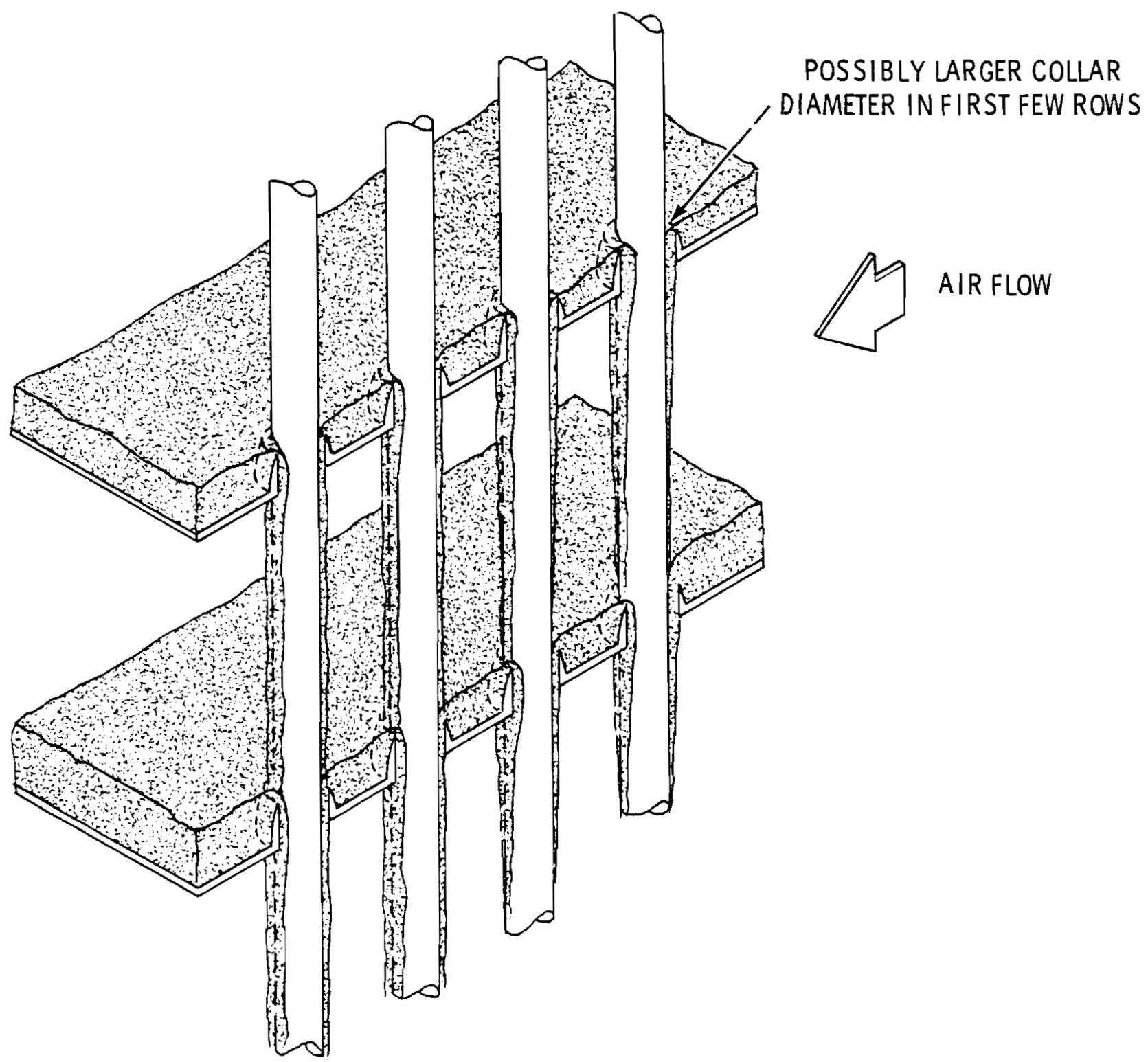

FIGURE 4-21. Plastic Heat Tube Heat Exchanger: Delugeate Application Details 


\section{TABLE 4-16. Fan Specifications for Plastic Tube}

Deluge Augmentation Concept

\begin{tabular}{|c|c|}
\hline Fan Diameter: & $28 \mathrm{ft}$ \\
\hline Blade Material: & Fiberglass \\
\hline Number of Blades: & 6 \\
\hline Blade Angle: & $11^{\circ}$ (Fixed Pitch) \\
\hline Flow Rate/Fan: & $\begin{array}{l}890,000 \mathrm{cfm}\left(\text { at } 109.7^{\circ} \mathrm{F}\right) \\
\text { and } 0.815 \mathrm{~atm}\end{array}$ \\
\hline Total Pressure: & 0.58 in. $\mathrm{H}_{2} \mathrm{O}$ \\
\hline Fan: & $74 \mathrm{hp}$ \\
\hline Motor: & Two speed $A C$ \\
\hline Direct Drive: & Gear Train \\
\hline
\end{tabular}

Louvers will be required around the entire circumference of each cooling tower for air flow control during high winds, deluging, and fill and drain operations. The louvers also protect the tube bundle during hail storms. The louvers will be constructed of primed carbon steel, and will rotate about the horizontal axis.

The louvers will be remotely controlled through mechaniçal linkages driven by electrical motors (four motors per quadrant, one motor for each level of louver assemblies). Each quadrant's louvers can be controlled separately. The top level of louver assemblies in each quadrant will also be controlled separately from the bottom three levels of louver assemblies.

\subsubsection{Water Flow Systems}

The recirculating system consists of cooling water pumps, distribution piping between the towers and the condenser and dump tank. The piping system associated with the cooling towers is illustrated in Figure 4-22.

The main piping system supplies cooling water to the general area of the cooling towers through an 84-in. diameter pipe approximately $1000 \mathrm{ft}$ long and buried $4 \mathrm{ft}$ below grade. The return line is similar. During cold weather, the towers can be bypassed completely to allow a reasonable temperature rise in the water before entering the towers. At the tower end of the 84-in. line, the flow is separated into two 66-in. lines, one for each tower. The recirculating pump is rated at $1.03 \times 10^{8} 1 \mathrm{~b} / \mathrm{hr}$ at $86 \mathrm{ft}$ head. 


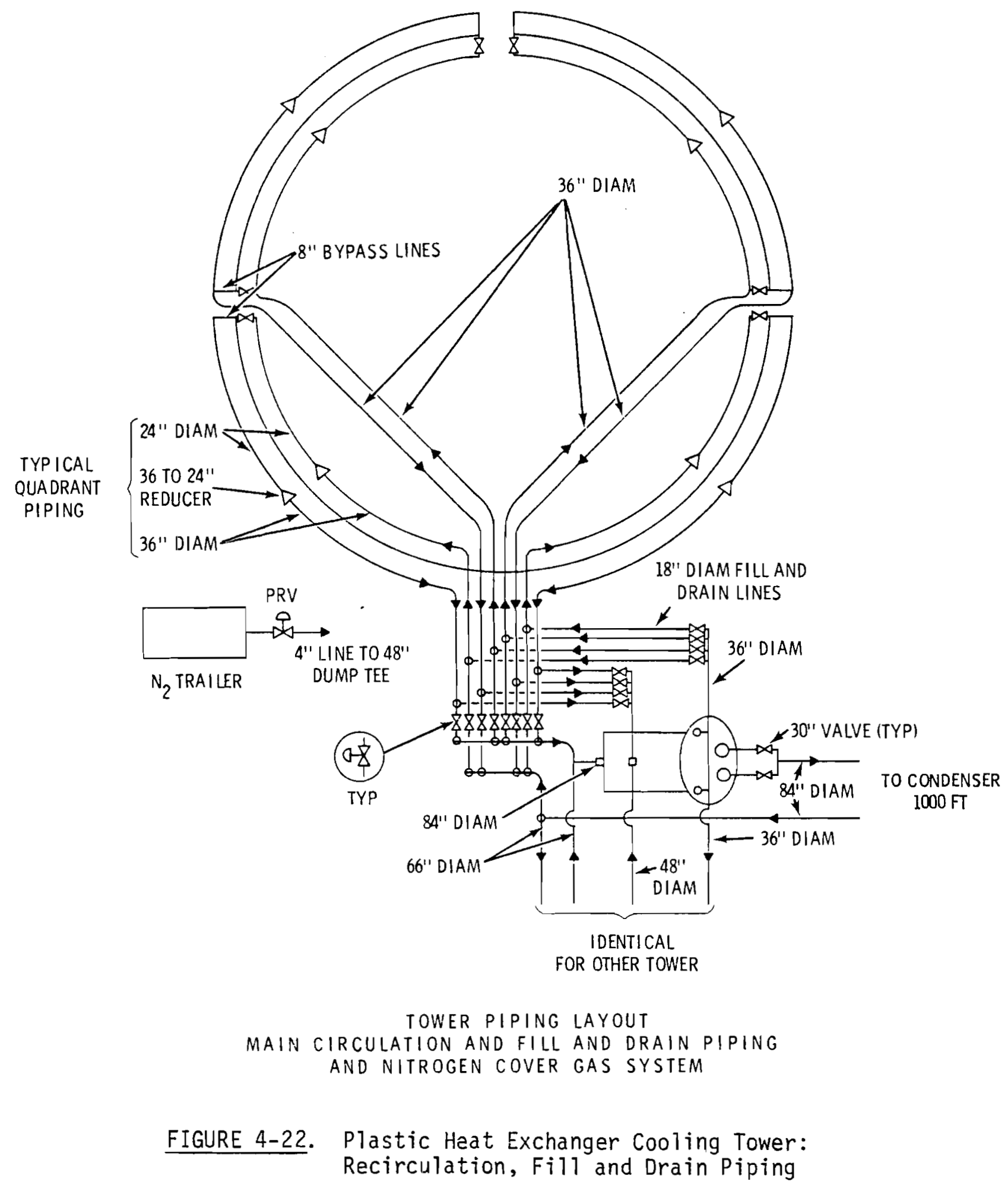


A fill and drain system is provided to start up and shutdown cooling tower quadrants to prevent freezing during cold weather. This system is capable of filling one quadrant at a time with prewarmed water from the dump tank in $90 \mathrm{sec}$ or less. Two fill pumps with a total capacity of approximately 18,000 gpm are used. The dump system drains all tower piping and heat exchangers into a 250,000-gal below-grade dump tank within $90 \mathrm{sec}$.

The deluge system is shown schematically in Figure 4-23. It consists of a plastic-lined concrete storage reservoir $(50,000$ gal), a deluge pump $(10,000 \mathrm{gpm}$ and $80 \mathrm{ft} / \mathrm{TDH})$, recirculating piping and a water treatment facility. The method of distributing deluge water over the heat exchanger was described previously. The total water flow rate when both towers are fully augmented is $20,000 \mathrm{gpm}$.

A cover gas system is provided to maintain a net positive suction head on the pumps and prevent oxygen from entering the system, thus reducing corrosion.

The cover gas system pressure will be sufficient to maintain a pressure of 2 psig at the top of the bundles. The cover gas $\left(\mathrm{N}_{2}\right)$ will be passed into the heat exchange bundles at the top upon drainage. The double-pass heat exchangers will be allowed to drain to the storage tanks from both tube passes. It is anticipated that enough cover gas to fill the entire heat exchanger will be required.

The recirculating water system is supplied with makeup water from a 10-gpm capacity water treatment plant. The treatment includes deionization, deaeration and $\mathrm{pH}$ control.

The required water quality control parameters are:

$\begin{array}{lc}\text { Total Dissolved Solids } & <150 \mathrm{mg} / \mathrm{l} \\ \text { Total Hardness } & <50 \mathrm{mg} / \mathrm{l} \\ \text { Oxygen } & <50 \mu \mathrm{g} / \mathrm{l} \\ \mathrm{pH} & 9.5\end{array}$




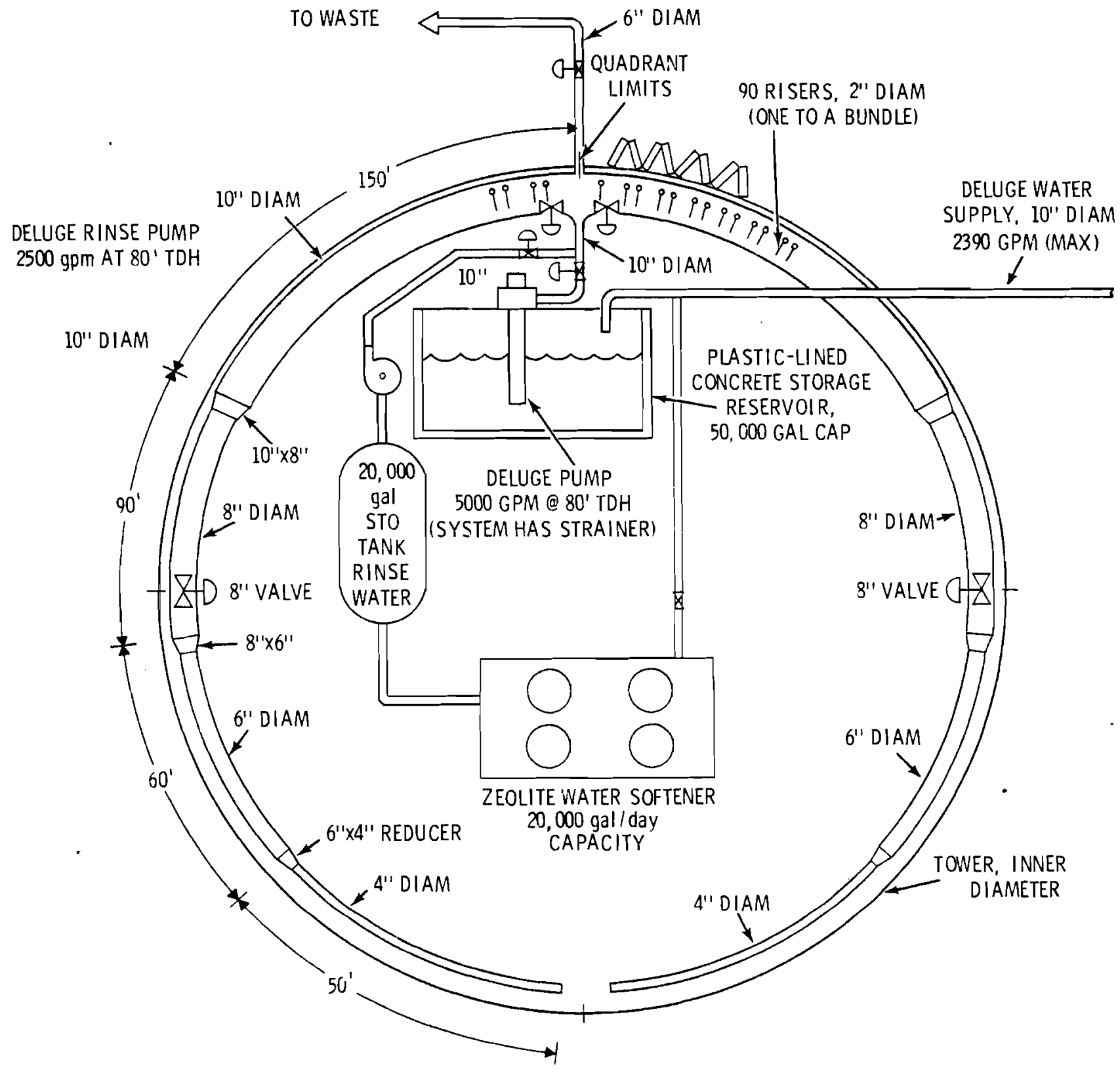

DELUGE PIPING - PLAN

NOTES: 1. ALL DELUGE PIPING IS PLASTIC

2. 2-INCH RISERS, FROM BOTTOM OF BUNDLE ON UP, ARE PART OF THE BUNDLE

FIGURE 4-23. Plastic Heat Exchanger Cooling Tower: Deluge Piping System 
Dissolved solids should be kept lower than $150 \mathrm{mg} / \mathrm{l}$ if possible. The $\mathrm{pH}$ control should be maintained using sodium hydroxide or potassium hydroxide and phosphate. The phosphate should be dosed to around $45 \mathrm{mg} / \ell$ as $\mathrm{PO}_{4}$; total alkalinity should be maintained at about $250 \mathrm{mg} / l$ as $\mathrm{CaCO}_{3}$.

A total volume of $6.15 \times 10^{8} \mathrm{gal}$ of water from the San Juan River is the maximum available for use in the deluge system each year. The deluge water should be maintained with a Langlier Saturation Index of zero or slightly negative. The water quality parameters shown below satisfy this requirement.

$\begin{array}{lc}\text { Calcium Hardness } & 160 \mathrm{mg} / \ell \text { as } \mathrm{CaCO}_{3} \\ \text { Total Alkalinity } & 140 \mathrm{mg} / \ell \text { as } \mathrm{CaCO}_{3} \\ \text { Total Dissolved Solids } & 500 \mathrm{mg} / \ell \\ \text { pH } & 7.3\end{array}$

Because this system is open, no attempt is made to deoxygenate the deluge water. At maximum deluge system use, approximately $4000 \mathrm{gpm}$ of water is evaporated. The required makeup water quality should exceed the above values. The water quality parameters for the makeup water are:

$\begin{array}{ll}\text { Total Hardness } & 20-40 \mathrm{mg} / \ell \text { as } \mathrm{CaCO}_{3} \\ \text { Caicium Hardness } & 15-30 \mathrm{mg} / \ell \text { as } \mathrm{CaCO}_{3} \\ \text { Total Alkalinity } & 10-25 \mathrm{mg} / \ell \text { as } \mathrm{CaCO}_{3} \\ \text { Total Dissolved Solids } & 50-100 \mathrm{mg} / \ell \\ \text { pH } & 6.5 \text { to } 7.5\end{array}$

The listed water qualities for the delugate and its makeup are maintained if 5.5 cycles of concentration are allowed. The maximum deluge flow rate is $20,000 \mathrm{gpm}$. At 5.5 cycles of concentration, the blowdown rate is $890 \mathrm{gpm}$ (blowdown) or $4890 \mathrm{gpm}$ will be required.

Whenever a tower quadrant is changed from wet to dry operation, the tube surfaces are rinsed with a low flow of demineralized water. Assuming that the entire tower system is switched from wet to dry at one time, 10,000 gal of sodium-zeolite treated water would be required. A requirement of two wetto-dry switches per day exists. Thus a 20,000 gal/day treatment capacity is required along with a 10,000-gal open tank per tower. 


\subsubsection{Condenser}

The condenser used for this concept is essentially identical to the condenser specified for the San Juan Unit 3 and is described in Section 4.1.

\subsubsection{Controls and Instrumentation}

The controls and instrumentation system is similar to the system conceptually designed for the metal tube/ deluge augmentation concept and is outlined in Section 4.3.

\subsection{METAL FIN-TUBE/DELUGE AUGMENTATION/AMMONIA HEAT TRANSFER SYSTEM CONCEPT}

\subsubsection{General Description}

This concept is similar to the metal fin-tube/deluge water augmentation concept with the exception that the heat transport system between the condenser and the cooling towers employs evaporating and condensing ammonia rather than single-phase water.

Exhaust steam from the last stage of the turbine is condensed in the condenser/reboiler located directly below the turbine. Liquid ammonia is partially evaporated as it is pumped through the tubes of the reboiler. The flow rate of ammonia is regulated to yield outlet vapor qualities of 50 to 90 percent. The vapor is separated from the mixture and piped to the direct condensing cooling tower; the remaining liquid is recycled through the reboiler. The driving force for the ammonia vapor transport from the reboiler to the condenser is the difference between the saturation pressures in these components. Condensed liquid ammonia is returned to the reboiler by gravity-primed pump.

The cooling towers are circular in geometry and house the ammonia condenser heat exchange surface. The heat exchanger is composed of vertically-oriented spiral-wound finned tubes. Heat is transferred from the condensing ammonia to the air passing over the outside heat exchange surfaces.

The cooling tower is designed to operate as a completely dry system during the cooler periods of the year. When the air temperature is sufficiently high, a portion of the heat exchange surface is deluged with water on the outside of the finned tubes to increase heat rejection capability. 
In this way, sensible heating of the air is augmented by heat transfer to the air by evaporation of the deluge water. The overall tower design is based upon the maximum use of available water for augmentation with minimum amount of heat exchange surface area.

This concept utilizes two cooling towers located between north coordinates $2,112,700$ and $2,113,100$ and east coordinates 322,300 and 322,800 , as shown in Figure 4-24. Each tower is capable of dissipating one-half the design heat load.

\subsubsection{Design Parameters}

The general features of the cooling towers used in this concept are provided in Figure 4-25. Each tower can be operated dry, al1-wet or partially wet. The air flow through each tower is induced mechanically with 31 fans, $28 \mathrm{ft}$ in diameter, mounted at the top of the tower structure. Heat exchanger units (159 fin-tubes/unit) are arranged in a series of A-frame configurations around the tower. Water for heat exchange augmentation is sprayed and flowed onto the fin-tubes in similar manner as described in Section 4.3. Hail screens are provided to protect the heat exchanger units. Specific information on the cooling tower system at design conditions is provided in Table 4-17.

With this cooling system design, all the heat load from the power plant can be rejected at $55^{\circ} \mathrm{F}$ ambient or below during dry operation. Above $55^{\circ} \mathrm{F}$, sections of the tower must be supplied with deluge water to dissipate the required amount of heat.

\subsubsection{Heat Exchangers}

Each heat exchanger unit contains 159 fin tubes. There are two units per A-frame, 20 or 22 units per tower quadrant, 84 units per tower and 168 total units. The tubes are staggered on an equilateral pitch with a transverse pitch of $2.615 \mathrm{in}$. The tubes are arranged for single pass with appropriate header design. Tube ends are welded to the headers to assure sealing. Each bundle is preassembled with a 24-in. channel on each edge of the bundle. The bundle tubes are $55 \mathrm{ft}$ long and the overall bundle length is approximately $57 \mathrm{ft}$. The bundles are mounted vertically in A-frames around the tower. Specifications for these heat exchanger units are provided in Table 4-18. 


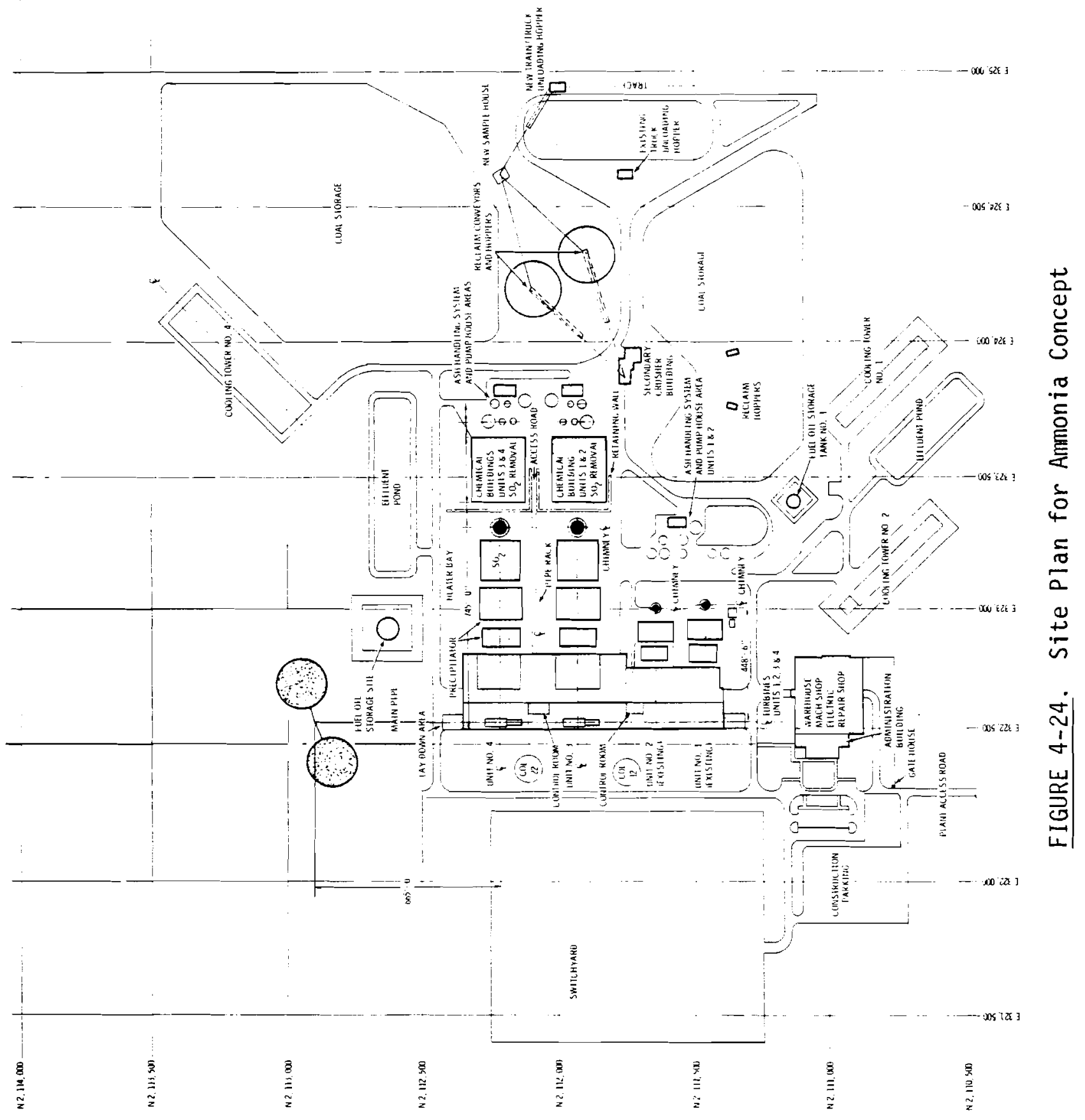




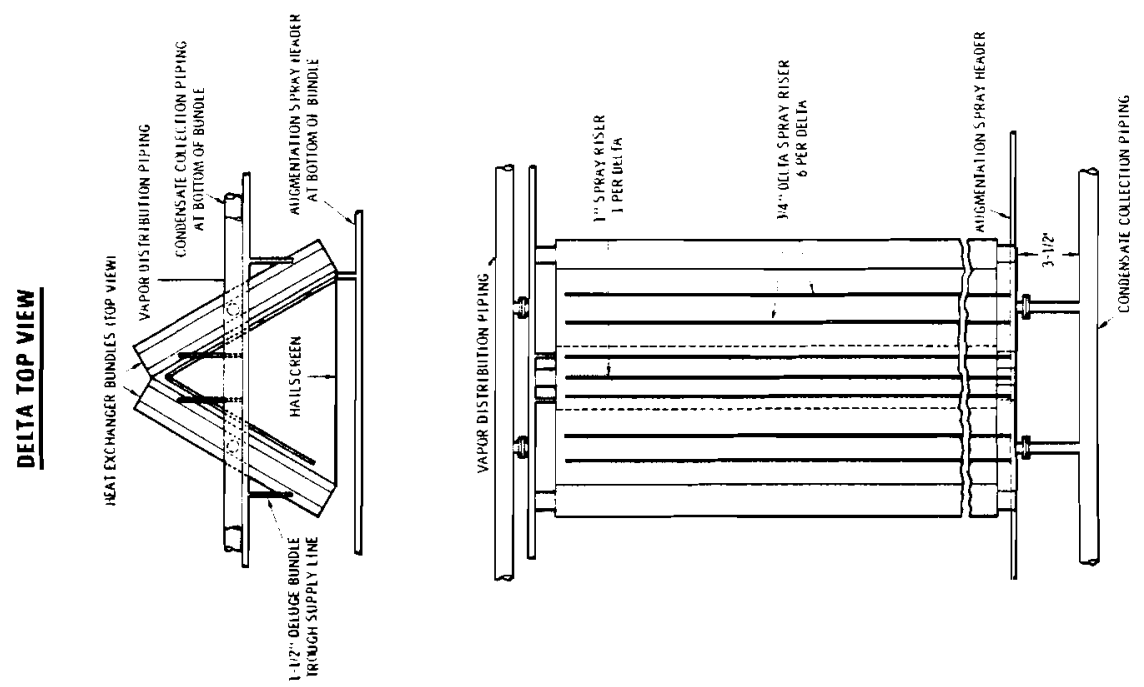

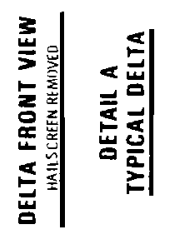
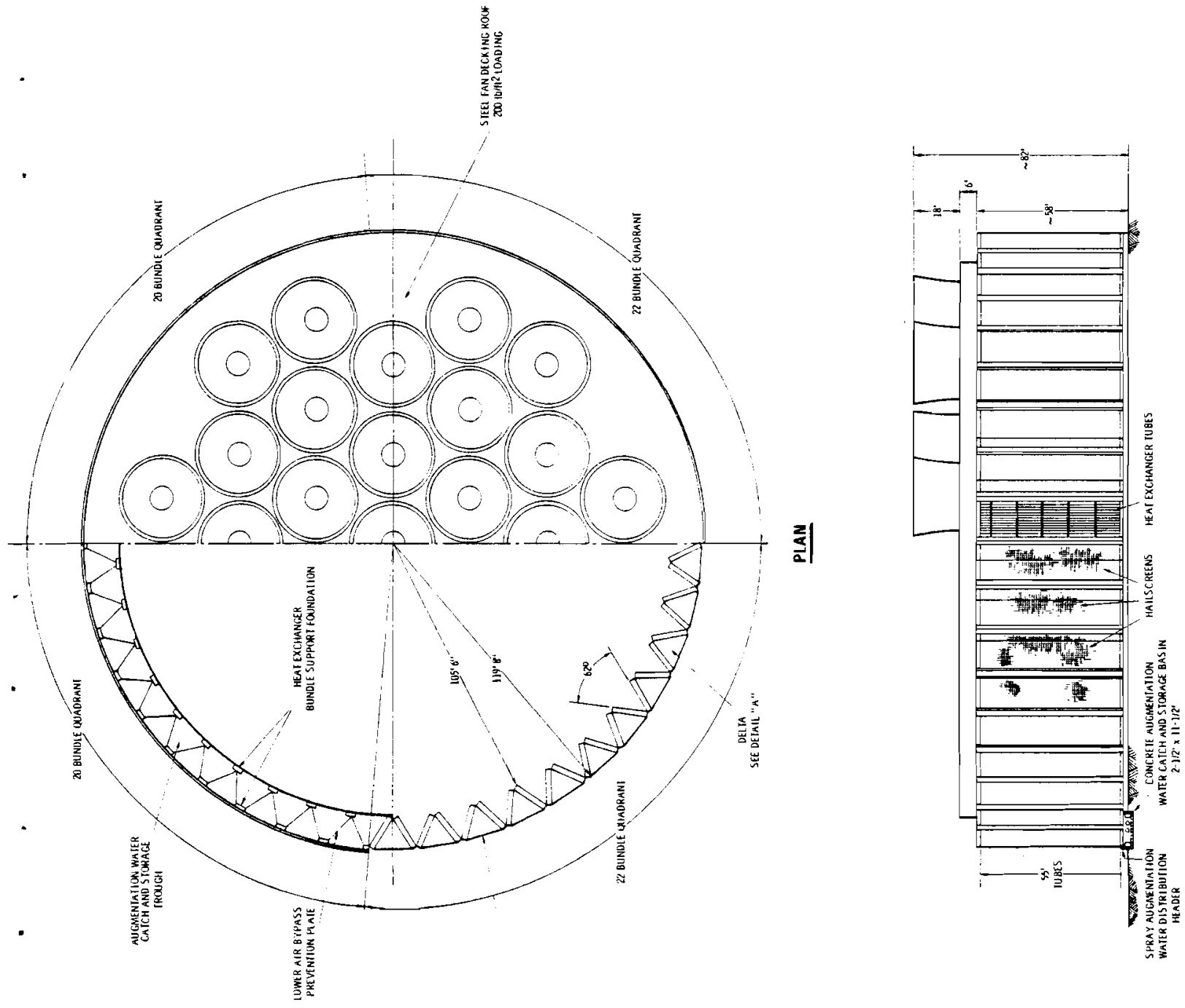

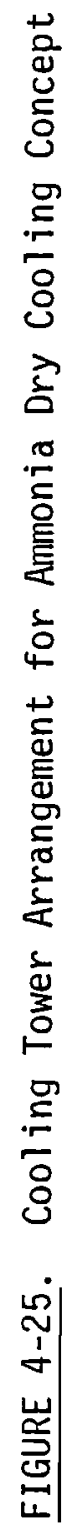




\section{TABLE 4-17. Ammonia Concept Design Information}

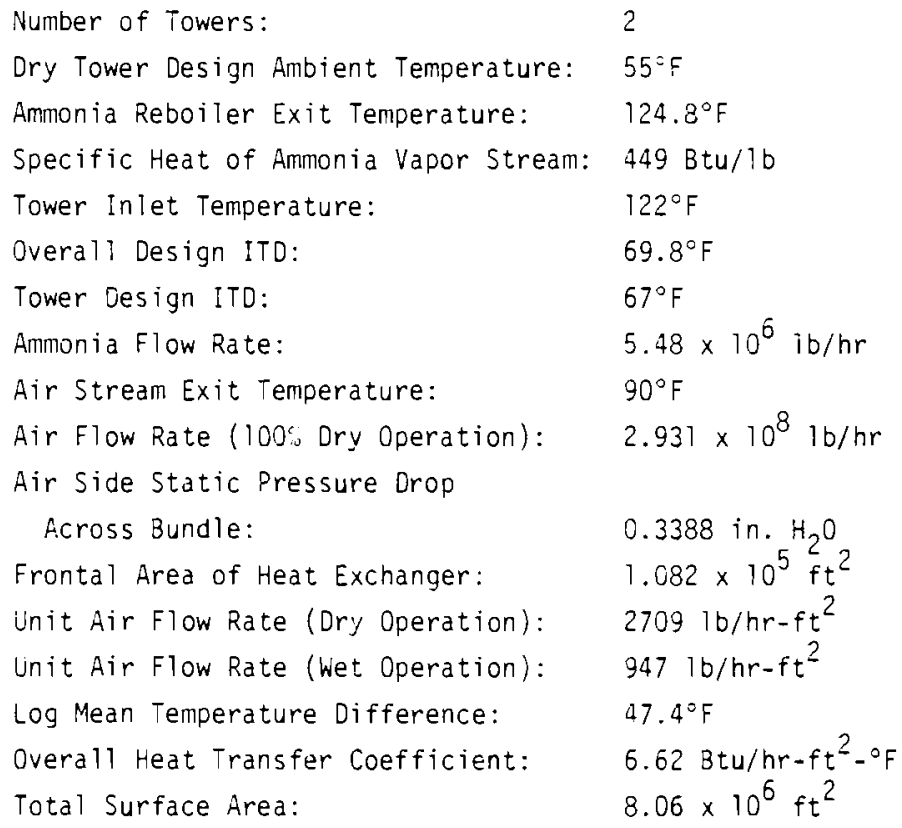

\section{TABLE 4-18. Specifications for Heat Exchangers Used for Ammonia Concept}

$\begin{array}{ll}\text { Type Tubes: } & \text { Extruded spiral fin } \\ \text { Materials: } & \text { Aluminum fins, Aluminum tubes } \\ \text { Tube OD: } & 1.00 \mathrm{in.} \\ \text { Tube ID: } & 0.916 \mathrm{in} . \\ \text { Fin Pitch: } & 10 / \mathrm{in} . \\ \text { Fin OD: } & 2.250 \mathrm{in} . \\ \text { Fin Thickness: } & 0.018 \mathrm{in} . \\ \text { Fin Spacing: } & 0.082 \mathrm{in} . \\ \text { Tube Length: } & 55 \mathrm{ft} . \\ \text { Number of Tubers per Unit: } & 159 \\ \text { Number of Units per Tower: } & 84 \\ \text { Total Number Fin-Tubes: } & 26,712 \\ \text { Number of Passes: } & 1 \\ \text { Number of Rows Deep: } & 3 \\ \text { Bundle Width: } & 12 \mathrm{ft} \\ \text { Tube Geometry: } & \text { Staggered, equilateral } \\ \text { Tube Transverse Pitch: } & 2.615 \mathrm{in} .\end{array}$


At high ambient conditions deluge water is applied to the normally dry exterior surface of the fin-tubes. This water is supplied by the trough and scupper arrangement to flow the water over the exterior of the tube fins. Water is also supplied by spray nozzles to supplement evaporation. The method used for application of the delugate is similar to that already discussed in Section 4.3.

\subsubsection{Fans and Louvers}

Specifications for the induced draft fan system used in this concept are given in Table 4-19.

\section{TABLE 4-19. Specifications of Fans Used for Ammonia Concept}

$\begin{array}{ll}\text { Fan Diameter: } & 28 \mathrm{ft} \\ \text { Blade Material: } & \text { Fiberglass } \\ \text { Number of Blades: } & 6 \\ \text { Blade Angle: } & 18^{\circ} \\ \text { Flow Rate/Fan: } & 1,384,380 \\ \text { Total Pressure: } & 0.4466 \mathrm{in} . \mathrm{H}_{2} \mathrm{O} \\ \text { hp/Fan: } & 125 \mathrm{hp} \\ \text { Inlet Be11: } & 5 \mathrm{ft} \mathrm{long,} 6.9 \mathrm{ft} \text { radius, } \\ & \text { max dia } 31.5 \mathrm{ft} \\ \text { Velocity Recovery Stack: } & 18 \mathrm{ft} \mathrm{long,} 7^{\circ} \text { angle } \\ \text { Construction: } & \text { Fiberglass for stack, } \\ & \text { carbon steel for bell } \\ \text { Number of Fans per Tower: } & 31 \\ \text { Total Number of Fans: } & 62 \\ \text { Blades: } & \text { Fixed pitch } \\ \text { Drive: } & \text { Gear train }\end{array}$

No louvers are specified; however, hail screens are mounted across each two-unit delta to provide protection from hail and wind-driven debris. 


\subsubsection{Piping System}

A flow diagram of the ammonia piping system is shown in Figures 4-26 and 4-27. A11 vapor lines are above-grade. The main vapor line transports ammonia from the separator to the general area of the cooling towers and is $48 \mathrm{in.}$ in diameter and approximately $1000 \mathrm{ft}$ long. The vapor line then splits into two 36-in. lines, each supplying one tower. At each tower the 36-in. line divides into four 20-in. lines, each supplying a quadrant. The condensed liquid ammonia is drained from the bottom of each heat exchange unit into a collection header 3-1/2 ft below the heat exchangers which runs around the inside periphery of the tower. Twenty-inch lines from each tower are sloped to carry the condensed liquid $60 \mathrm{ft}$ to the condensate return pumps. These pumps (two each, 10,000 gpm at $27 \mathrm{ft} / \mathrm{TDH}$ ) return the total flow of condensate to the reboiler separator. Liquid ammonia is recirculated back into the reboiler by means of two pumps $(20,000 \mathrm{gpm}$ at $30 \mathrm{ft} / \mathrm{TDH})$.

A11 components of the ammonia system are designed to withstand maximum system pressure of $350 \mathrm{psi}$ at $150^{\circ} \mathrm{F}$. Material for piping and tanks is carbon stee 1 (ASTM A-53, grade B or ASTM A-139, grade B or equivalent). Fittings are carton steel (ASTM A-234, ANSI B16.9, or MSS SP-48) and valves are flanged carbon steel (API 6D).

Ten storage vessels with 7,750-gal capacity are provided to hold the entire anmonia inventory during maintenance or in case of emergency. The system is drained and filled through $8-i n$. lines by means of a 2,500 gpm at $50 \mathrm{ft}$ TDH pump. Vapor vent lines are 3-1/2 in. in diameter.

A nitrogen purge system is provided to purge air from the ammonia system following maintenance or repair. A vent and flow system is also provided to remove ammonia vapor from the cooling tower heat exchangers.

The deluge system is capable of augmenting the entire heat exchanger surface. Augmentation of these surfaces is accomplished by flowing water at the rate of $0.2 \mathrm{gpm} /$ tube down the full length of the fin-tubes. The method of applying deluge water is similar to that discussed in Section 4.3. In addition to deluge water, water is also sprayed through nozzles onto the front face of the heat exchange units at the rate of $0.9 \mathrm{gpm} /$ tube. The deluge flow provides a solid water film to prevent corrosion of the extended surfaces; the spray provides air/water interfacial area required for adequate evaporation. 


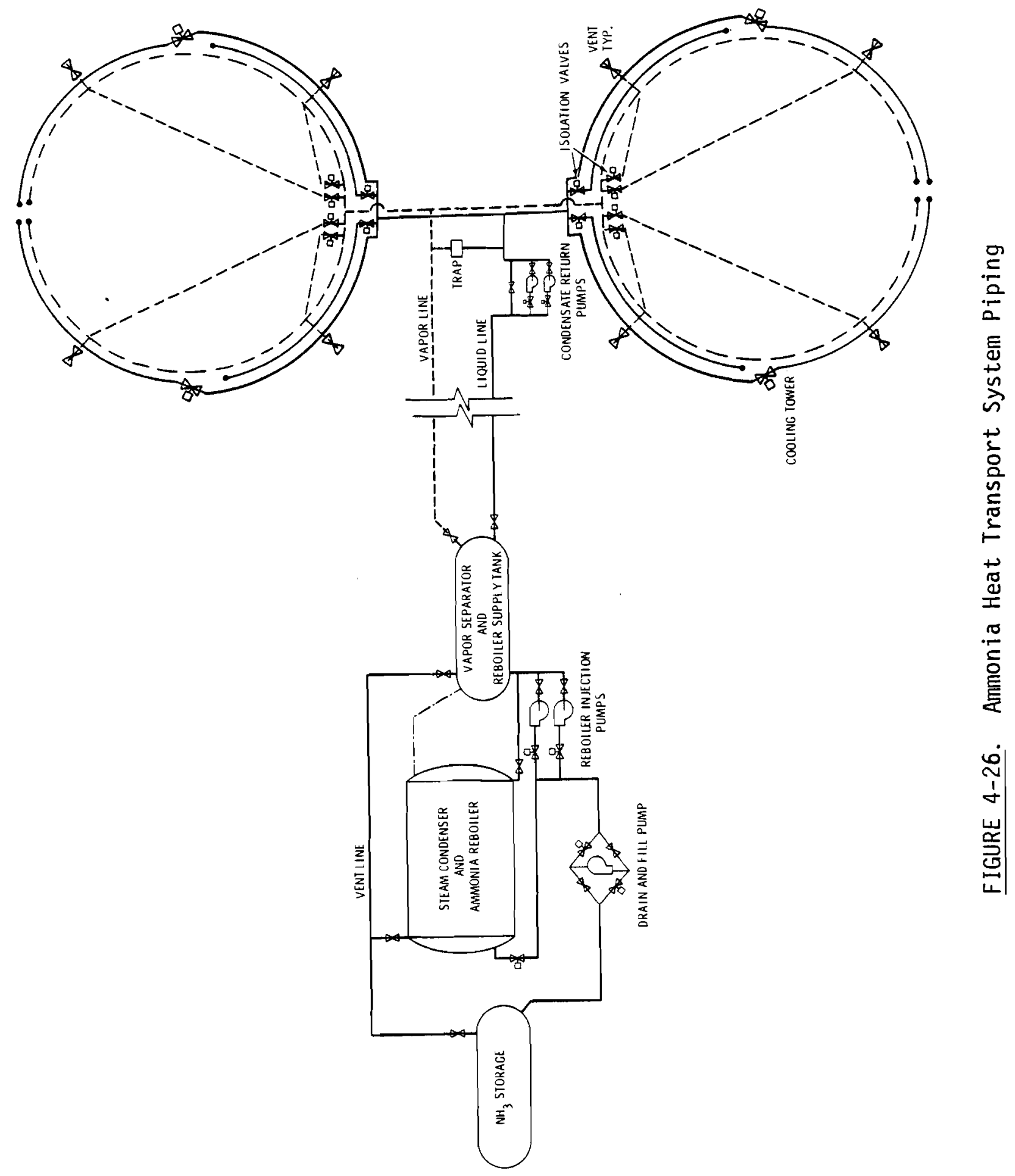




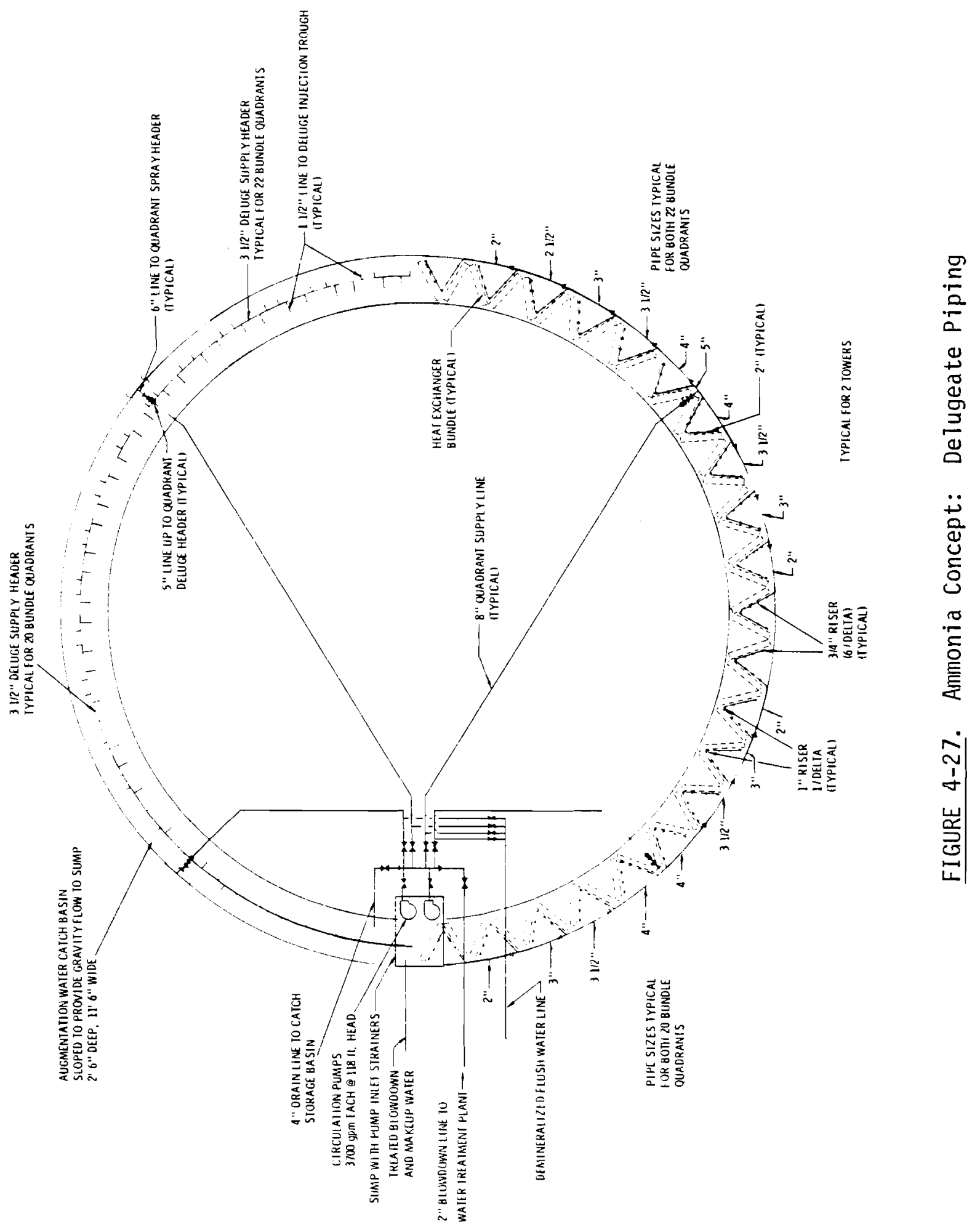


The deluge piping system is composed of two separate subsystems, one for each tower. Each subsystem is composed of 1) two deluge pumps, 2) water storage basin, 3) distribution piping, 4) spray nozzles, and 5) deluge water distribution channels integrated with the heat exchangers. Each deluge pump is rated at 3,700 gpm at $118 \mathrm{ft} \mathrm{TDH}$. The pumps take water from the circular concrete channel which functions as both a collection and storage basin. The 12-in. discharge line from the pump supplies four 8-in. branch lines which supply the four quadrants of the cooling tower. The 8-in. branch lines supply additional branches distributing water to the deluge troughs and the spray nozzles. After the deluge water passes over the heat exchanger surfaces it is collected by the circular collection basin.

A maximum of $5.13 \times 10^{9}$ gal is available annually from the San Juan River for use in the deluge system. Maximum instantaneous consumptive use is $4000 \mathrm{gpm}$. Because the system is open, no deoxygenation is specified; water treatment will consist of sulfuric acid addition to control pH to 7.6-7.8 and blowdown (800 gpm) to maintain a sufficiently low dissolved solids concentration. The blowdown will undergo lime softener treatment, and the effluent from the treatment plant will be recycled into the deluge system. Sludge from the softener ( $85 \mathrm{gpm})$ will be discarded to the effluent pond.

Whenever a tower is changed from wet to dry operation, the tube surfaces will be flushed with zero hardness water for five minutes (400 gpm/quadrant). Water containing less than $5 \mathrm{ppm}$ calcium as $\mathrm{CaCO}_{3}$ will be produced by passing 24,000 gal/day of excess deluge makeup through a sodium zeolite water softening plant. The demineralized water will be stored in a 24,000-gal open storage tank.

\subsubsection{Control and Instrumentation}

The overall control of the cooling tower is accomplished through the use of a microprocesser. Important control functions include:

- fan control

- ammonia leak detection

- liquid ammonia level control

- reboiler exit vapor quality control

- dry/wet split control 
- water use monitoring

- meteorological measurement

- back pressure control

- emergency shutdown procedures

The ammonia cooling system will be operated in an automatic mode with the aid of a microprocesser when the ambient air temperature and relative humidity are within certain limits. At an ambient temperature of $55^{\circ} \mathrm{F}$ or below, the system will automaticaliy be operated dry at the lowest possible back pressure. Above this temperature, the control system will automatically determine the amount of wet operation required.

In this automatic mode the microprocesser will receive input information including:

- turbine back pressure

- plant power level

- ambient air temperature

- relative humidity

- tower status

- current amount of wet operation

- cumulative water usage

- selected temperatures and pressures throughout the system

- selected flow rates

- selected liquid levels

- leak detection monitoring.

The microprocesser will analyze input data and take appropriate action to maintain the desired back pressure and economic water use. The control system wil1 record system components or segments which are out of service.

The control system will have set procedures established for routine shutdown and evacuation, emergency shutdown in case of a hazardous ammonia leak, and startup. If a dangerous ammonia leak is dętected, the control system will sound an alarm and initiate the shutdown and isolation of the particular tower, quadrant, or component in question. 


\subsection{BASES FOR COST ESTIMATES}

The cost estimates for construction and annual operation were based on a variety of sources, documented in this section.

\subsection{CONSTRUCTION COSTS}

Construction costs for the five concepts described in Section 4.0 were estimated from conceptual designs prepared from system descriptions. Copies of these system descriptions may be obtained from the PNL Dry Cooling Tower Project. Conceptual designs and construction costs estimates were both performed by Vitro Engineering, a division of Automation Industries, Inc.

Costs for materials and equipment items were obtained from discussions with suppliers including The Marley Company (cooling towers), Ameron (concrete pipe), Pheips Dodge (condenser tubing), Sheldon Plastic Co. (polyethylene pipe), Ingerso11-Rand (condensers), Johnston Pump Co. (pumps), Betz Laboratories (water treatment and demineralizers), etc. The costs for cooling tower fans, heat exchangers and louvers were obtained from a recent survey and correlation of costs for this equipment classification. (3)

Labor costs for defined work to be accomplished were derived from such sources as Richardson Engineering Services, Inc., and R. S. Means Co. Area craft rates obtained from the Federal Register were used to reflect the geographical rocation under consideration.

Genera1 contractors' overhead was assumed to be 14 percent of labor costs; profit was assumed as 10 percent of labor and equipment and 5 percent of subcontractors' cost. Engineering services and construction management were each estimated at 10 percent of construction costs.

Escalation was calculated at the rate of 0.79 percent per month for the balance of 1976 and at a rate of 10 percent per year thereafter to the midpoint of construction, which was assumed to be January 1, 1979. 


\subsection{ANNUAL OPERATING COSTS}

Operating costs for the heat rejection system concepts considered in this report include recirculating system pumping costs, fan power costs, deluge water pumping costs, cover gas costs, water treatment costs and ammonia makeup costs (where applicable). Normal maintenance costs were assumed to be approximately the same for all concepts and were not included in the operating cost estimate.

The annual operating cost was credited for fuel savings resulting from lower turbine back pressure made possible by each particular concept. These cost savings were estimated from plant heat rate data for San Juan Unit 3 and were defined as savings over those costs associated with the existing design. In all cases, all water available for consumptive use $\left(6.15 \times 10^{8}\right.$ gal annually) was assumed to be used for cooling purposes subject only to a maximum instantaneous flow limitation of $4000 \mathrm{gpm}$. Other data used in defining operating costs are as follows:

- Year of pricing: 1976

- Plant size: 550,000 kWe

- Capacity factor: 0.758

- Cost of power consumed by auxiliary equipment: $24.7 \mathrm{mills} / \mathrm{kWh}$

- Turbine back pressure: $4.5 \mathrm{in}$. Hg rated; $1.0 \mathrm{in.} \mathrm{Hg}$ min.

- Standard heat rate: 8,168 Btu/kWh

- Fuel costs: $81 \phi$ MMBtu.

The San Juan River was assumed to be the only source of water to the cooling tower and a separate water treatment plant for the cooling towers was assumed. The assumed river water analysis was given in Section 3.3.

To facilitate comparison of the concepts under study, operating costs were capitalized on the basis of the fixed charge rate of 18 percent of annual operating costs as defined above. 


\subsection{RESULTS}

The capital and operating costs determined in this analysis are presented in this section. Comparative capital costs for the five concepts are also included.

\subsection{CAPITAL COSTS OF ALTERNATIVE CONCEPTS}

A summary of the estimated capital costs of constructing the five alternative heat rejection concepts for the San Juan Plant Unit 3 is provided in Table 6-1.

TABLE 6-1. Results of Capital Cost Estimates of Alternative Heat Rejection Concepts for San Juan Unit 3 (\$ Thousands, 1976)

Estimated

Capital Cost Escalation Contingency Tota?

Integrated Dry/Wet (Baseline)

$\$ 22,789$

$\$ 5,638$

$\$ 8,573$

$\$ 37,000$

Separate Dry/wet

29,276

7,243

10,981

47,500

Metal Fin-Tube/Deluge

28,882

7.145

10,773

46,800

Plastic Tube/Deluge

24,311

6,014

9,075

39,400

Deluge/Ammonia Heat Transport

23,128

5,721

8,651

37,500

A11 estimates summarized in Table 6-1 are subject to the validity of assumptions defined in Sections 2.0 and 5.0. The integrated dry/wet concept is considered as a baseline for comparison because it represents current practice. The San Juan Plant Unit 3 is currently being constructed with a heat dissipation system of this type. The estimate of the integrated dry/wet concept was performed without the benefit of prior knowledge of actual construction costs of San Juan Unit 3 and may or may not correspond to actual costs.

A breakdown of the costs summarized in Table 6-1 is provided in Table 6-2. Additional details may be requested from the author(s). 


\section{TABLE 6-2. Breakdown of Capital costs of Alternative Concepts ( $\$$ Thousands)}

\begin{tabular}{|c|c|c|c|c|c|c|}
\hline Item & Design & $\begin{array}{l}\text { Integrated } \\
\text { Dry/wet }\end{array}$ & $\begin{array}{l}\text { Separate } \\
\text { Dry/Wet }\end{array}$ & $\begin{array}{c}\text { Metal Fin-Tube } \\
\text { Deluge } \\
\end{array}$ & $\begin{array}{c}\text { Plastic Tube } \\
\text { Deluge }\end{array}$ & $\begin{array}{c}\text { Deluge } \\
\text { Ammionia System }\end{array}$ \\
\hline Steam Condenser & 1 & 1,740 & 2,848 & 1,740 & 1,740 & 2,653 \\
\hline \multicolumn{7}{|l|}{ Cooling System } \\
\hline Piping & 2 & 1,631 & 2,090 & 1,439 & 929 & 1,275 \\
\hline Tanks & 3 & & 574 & 574 & 714 & 310 \\
\hline Pumps & 4 & 338 & 610 & 376 & 381 & 262 \\
\hline System Subtotal & & 1,969 & 3,273 & 2,388 & 2,024 & 1,847 \\
\hline \multicolumn{7}{|l|}{ Fill and Drain System } \\
\hline Piping & 5 & 245 & 493 & 447 & 143 & 232 \\
\hline Tanks & 5 & & & & & 514 \\
\hline Pumps & 7 & 14 & 60 & 51 & 78 & 35 \\
\hline System Subtotal & & 259 & 553 & 498 & 221 & 781 \\
\hline \multicolumn{7}{|l|}{ Water Quality Control } \\
\hline Water Treatment & 8 & 495 & 409 & 554 & 554 & 290 \\
\hline Demineralized Water & 9 & & 264 & 187 & 270 & 167 \\
\hline Piping and Pumps & & & 325 & 317 & 226 & 335 \\
\hline System Subtotal & & 495 & 998 & 1,058 & 1,050 & 792 \\
\hline Cover Gas System & 10 & & 136 & 141 & 143 & 143 \\
\hline \multicolumn{7}{|l|}{ Cooling Towers } \\
\hline Structural Work & 11 & 1,647 & 1,557 & 1,728 & 1,525 & 1,334 \\
\hline Piping & 12 & 1,160 & 1,996 & 2.483 & 2,603 & 984 \\
\hline Pumps & 13 & & & 152 & 58 & 106 \\
\hline Heat Transfer & 14 & 4,686 & 3,825 & 5,440 & 4,006 & 3,976 \\
\hline Fans & 15 & 2,046 & 2,415 & 1,908 & 1,142 & 1,742 \\
\hline Louvers & 16 & & 686 & 744 & 720 & \\
\hline System Subtotal & & 9,539 & 10,479 & 12,455 & 10,054 & 8,142 \\
\hline Buildings & & 52 & 71 & 52 & 52 & 52 \\
\hline Electrical work & & 2,015 & 2,246 & 1,907 & 1,811 & 1,666 \\
\hline SUBTOTALS & & 16,069 & 20,605 & 20,239 & 17,094 & 16,075 \\
\hline Contractor's $\mathrm{OH}$ and Profit & & 2,922 & $3,79 !$ & 3,829 & $3,164.8$ & 3,199 \\
\hline Eng. and Constr. Mgt. & & 3,798 & 4,880 & 4,814 & 4,052 & 3,854 \\
\hline Escalation & & 5,638 & 7,243 & 7,145 & 5,014 & 5,721 \\
\hline Contingency & & 8,573 & 10,981 & 10,773 & 9,075 & 8,651 \\
\hline TOTALS & & 37,000 & 47,500 & 46,800 & 39,400 & 37,500 \\
\hline
\end{tabular}




\subsection{OPERATING COSTS}

The annual operating costs for the five dry/wet cooling tower concepts under study were estimated using assumptions and data provided in Section 5.2. The results of these estimates are summarized in Table 6-3.

\section{TABLE 6-3. Estimated Annual Operating Costs (\$/Year)}

\begin{tabular}{|c|c|c|c|c|c|c|}
\hline System & $\begin{array}{l}\text { Circulation } \\
\text { Pump Cost }\end{array}$ & $\begin{array}{l}\text { Induced Draft } \\
\text { Fan Cost }\end{array}$ & $\begin{array}{c}\text { Reduced } \\
\text { Back Pressure } \\
\text { Savings } \\
\end{array}$ & $\begin{array}{c}\text { Water } \\
\text { Treatment } \\
\text { Cost } \\
\end{array}$ & $\begin{array}{l}\text { Deluge } \\
\text { Pump Cost }\end{array}$ & Total Cost \\
\hline Integrated Dry/Wet & 628,400 & $1,227,600$ & $-55,597$ & 330,000 & $-0-$ & $2,130,4 \cup 3$ \\
\hline Separate Dry/wet & 967,450 & $1,311,600$ & $-55,597$ & 356,000 & $-0-$ & $2,579,453$ \\
\hline Deluge/Finned Tube & 782,550 & $1,016,900$ & $-230,422$ & 130,000 & 13,130 & $1,712,158$ \\
\hline Plastic Tube & 650,400 & 598,000 & $-234,877$ & 131,000 & 7,530 & $1,152,053$ \\
\hline Ammonia & 34,300 & $1,047,350$ & $-220,257$ & 75,000 & 25,130 & 961,523 \\
\hline
\end{tabular}

It should be carefully noted that the costs specified in Table 6-3 include only those costs associated with the dry/wet cooling tower operation. These costs were credited for savings resulting from predicted lower back pressure than anticipated for the present San Juan Unit 3 design.

Costs for ammonia makeup in the deluge/ammonia concept have been included under "Water Treatment cost".

\subsection{COMPARATIVE CAPITAL SAVINGS}

To facilitate comparison of the total costs of the dry/wet cooling tower concepts under study, a "comparable capital cost" was identified for each concept. Comparable capital cost was defined as the sum of the estimated basic capital cost (i.e., estimated capital cost less escalation and contingency) and the capitalized annual operating cost. The capitalized annua] operating cost was based on estimated annual operating costs summarized in Table $6-3$ and on a fixed charge rate of 18 percent. 
The comparable capital costs of the five concepts considered in this report are summarized in Table 6-4.

TABLE 6-4. Summary of Comparative Capita1 Costs

\begin{tabular}{|c|c|c|c|}
\hline & $\begin{array}{l}\text { Basic Capital } \\
\text { Cost } \\
\end{array}$ & $\begin{array}{l}\text { Capitalized } \\
\text { Operating Cost }\end{array}$ & $\begin{array}{l}\text { Comparable } \\
\text { Capital Cost } \\
\end{array}$ \\
\hline Integrated dry/wet & $\$ 22,789,000$ & $\$ 11,836,000$ & $\$ 34,625,000$ \\
\hline Separate dry/wet & $29,276,000$ & $14,330,000$ & $43,606,000$ \\
\hline Metal fin-tube/deluge & $28,882,000$ & $9,512,000$ & $38,394,000$ \\
\hline Plastic tube/deluge & $24,344,000$ & $6,400,000$ & $30,744,000$ \\
\hline $\begin{array}{l}\text { Metal fin-tube/deluge/ } \\
\text { ammonia }\end{array}$ & $23,152,000$ & $5,342,000$ & $28,494,000$ \\
\hline
\end{tabular}




\subsection{DISCUSSION}

Results of the analysis are discussed in further detail in this section, followed by conclusions and recommendations.

\subsection{POTENTIAL COST SAVINGS OF ALTERNATIVE CONCEPTS}

Table 6-4 shows that, on the basis of conditions associated with the San Juan Plant Unit 3, two of the alternative dry/wet concepts considered have a potential of higher cost than the integrated dry/wet concept, the concept chosen as the basis for comparison and the one chosen for use in San Juan Unit 3. In addition, two have potentially lower costs, with the deluge/ammonia concept having significantly lower cost.

The two concepts showing potentially higher costs are the separate dry and wet tower and metal/deluge concepts. The separate tower concept has both higher capital and operating costs than the integrated tower. Higher capital costs result from the need for the more complex and costly divided condenser, two separate recirculating flow systems and the additional demineralization and deaeration facilities required by the closed loop. Operating costs are higher because of the additional water treatment costs and circulation pump charges. The metal/deluge concept capital costs are significantly higher than the integrated tower base case, but are comparable to the separate tower concept. These higher capital costs result from higher costs of a more complex cooling tower, the deluge and rinse systems, a cover gas system and the additional water treatment facility capabilities required for the closed recirculation system, deluge system and rinse system. Operating costs of the metal/deluge system are significantly lower than both the integrated and separate tower systems because of the credit associated with reduced turbine back pressure. This reduction of back pressure occurs during colder periods and is the result of the larger dry tower used in the deluge design, because a portion of the dry section is converted to an evaporative section when the deluge cooling is used. This lower back pressure is reflected by an improvement of plant heat rates and lower fuel costs. 
The two concepts showing potentially lesser costs than the base case are the plastic tube/deluge concept and the deluge/ammonia heat transport system concept. Earlier it was thought that a plastic tube cooling tower system would be less costly than an equivalent metal fin-tube tower system, and an examination of capital costs predicted in Table $7-2$ tends to verify this. However, this improvement was not sufficient to decrease its costs below those of the more simple integrated tower concept. Operating costs of the plastic systems were lower than the base case because of lower fan costs, reduced circulating pumping requirements and fuel savings from reduced back pressure resulting from more efficient use of available water. The lower fan costs resulted from the use of the very large frontal area for the plastic heat exchangers.

The deluge/ammonia system was found to have potentially lower capital costs, operating costs and comparable capital cost than any other concept considered in this study. Āithough this concept requires a rather expensive ammonia reboiler, rather than a simple condenser, and a complex pressurized ammonia fill and drain system, it has a number of important cost advantages associated with the evaporation-condensation heat transfer system. Among these are the enhanced heat transfer in the condenser and cooling tower, resulting in a substantial saving in tower costs, and the existence of natural forces to transmit vapor from the reboiler to the cooling tower. Only small pumps are required to return the ammonia to the reboiler and to provide forced recirculation. Water treatment plant costs are aiso less because of the need for treating only the delugate water.

Operating costs for the deluge/ammonia system are substantially less than the other concepts because 1) very little power is required to operate recirculation pumps and 2) fuel savings from lower back pressure result from the more efficient use of available water by deluging.

Although the resulits of this study have identified two concepts which have the potential for lower costs than the integrated dry/wet system selected for use in the San Juan Unit 3 , it is not inferred that an inappropriate selection was made. In fact, the results of this study support the application of the integrated dry/wet concept for the San Juan Plant since it was 
shown that it is the least costly of concepts investigated which are stateof-the-art or resemble state-of-the-art. The lower cost plastic deluge and deluge/ammonia concepts are developmental in nature and have not been subjected to conditions existing in commercial power operation. Therefore, unknown problems may exist with these concepts which have not been adequately reflected in this study. Additional testing and demonstration is required before a selection of these concepts for commercial power applications can be confidently made.

The costs presented in this report for all concepts studied are necessarily approximate in nature. Because of limited time and funding, it was not possible to research all site-related factors which could influence construction costs. Also, none of the were were fully optimized from the standpoint of all parameters involved as described in Section 3.0. However, all designs and estimates were arrived at utilizing the same bases and uniform procedures. It is not anticipated that exhaustive optimization would change the relative ranking of the concepts with regard to comparative capital costs. Therefore, it is believed that the results of this study are valid for comparative purposes as used herein. It is not recommended that cost figures presented in this report be used out of context of the comparisons intended.

The five concepts studied in this work were conceptually designed and cost estimates performed on the basis of assumptions identified in Sections 3.0 and 5.0. They are applicable only to conditions existing at the San Juan Unit 3 site and the results may change if the same study is performed in context of another site. The San Juan site cannot be said to be "typical". Its fuel costs are low and transportation costs high. However, the results of this study indicate that there may be economic incentives for developing "advanced" systems such as the plastic/deluge and the deluge/ammonia concepts. Each site has its own requirements and' any system would have to be designed and optimized for them in particular. The delay in utilizing attractive advanced concepts such as identified here will largely be due to engineering conservatism concerning new systems. The proof that advanced concepts can be successfully operated probably depends on the outcome of tests proving the reliability and performance of the concepts. The beneficiary of the success 
of these tests will be the public, for, until then, all dry cooling will be slower in coming and will result in more expensive plants and/or more water consumption .

\subsection{CONCLUSIONS AND RECOMMENDATIONS}

From the results of this study, it is concluded that the plastic tube/ deluge concept and the deluge/ammonia concept as described in Section 4.4 and 4.5 of this report, respectively, have potential cost advantages for use in power plant cooling applications under conditions imposed by the particular site studied. The deluge/ammonia concept could be particularly attractive because the results indicated a potential saving of almost 35 percent in total annual costs. It is recommended that additional attention be given to these concepts by industry and particularly by the ERDA Dry Cooling Tower Program to further quantify potential benefits within the context of other sites and to work toward providing the experimental data and operating experience required to demonstrate their performance and reliability. 


\section{REFERENCES}

1. E. C. Smith and M. Larinoff, Power, 78-80, 1976.

2. W. V. Loscutoff, Preliminary Evaluation of Wet/Dry Cooling Concepts for Power Plants. BNWL-1969, Batte11e, Pacific Northwest Laboratories, Richland, WA 99352, January 1976.

3. P. A. Ard, C. H. Henager, D. R. Pratt and L. E. Wiles, Costs and Cost Algorithms for Dry Cooling Tower Systems. BNWL-2123, Battelle, Pacific Northwest Laboratories, RichTand, WA 99352, September 1976. 


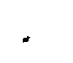


No. of

Copies

\section{OFFSITE}

No. of

Copies

\section{A.A. Churm \\ Chicago Patent Group \\ Energy Research and \\ Development Administration \\ 9800 Soūth Cass Avenue \\ Argonne, IL 60439 \\ Office of Assistant General \\ Counsel for Patents Energy \\ Research and Dvelopment \\ Administration \\ Washington, DC 20545 \\ 27 ERDA Technical Information Center}

10 I. Helms

Advanced Concepts Evaluation Branch - F-309

ERDA Division of Nuclear Research and Application

Washington, DC 20545

W.F. Savage

Chief, Advanced Concepts Evaluation Branch

ERDA Division of Nuclear Research and Application

Washington, DC 20545

D.C. Bauer

Director, Division of Nuclear Research and Application

Energy Research and Development Administration Washington, DC 20545

W.E. Mott

Director, Energy Control Technology ERDA Division of Biomedical and

Environmental Research

Washington, DC 20545
B.R. Dickey

Allied Chemical Company

550 2nd Street

Idaho Falls, ID 83401

J.S. Joyce

All is-Chalmers Power

Systems, Inc.

1135 South 70th Street

West Allis, WI 53214

E.T. Wanderer

Aluminum Company of America

Alcoa Technical Center

Alcoa Center, $\mathrm{OH} 45069$

H.J. Janzon

American Electric Power

2 Broadway

New York, NY 10004

T. Woods

Arizona Public Service Co.

2121 W. Chery 1 Drive

Phoenix, AZ 85021

M.W. Peterson

Babcock \& Wilcox

Fossil Power Divison

20 South Van Buren

Barberton, OH 44203

G.C. Creel

Baltimore Gas \& Electric Co. Gas \& Electric Building

Baltimore, MD 21203

E. Schinner

Baltimore Aircoil Co., Inc.

P.0. Box 7322

Baltimore, MD 21227 
No. of

Copies

J.P. Budliger

Battelle-Geneva

7 Route De Drizi

1227 Geneva, SWITZERLAIND

$P$. Leung

Bechtel Corporation

P.0. Box 60860

Terminal Annex

Los Angeles, CA 90060

G.R. Retti

Bechtel Corporation

P.O. Box 3965

San Francisco, CA 94119

J.P. Rossie

R.W. Beck and Associates

400 Prudential Plaza

Denver, C0 80202

B. Westre

Black Hills Power and Light Company

P.0. Box 1400

Rapid City, SD 57701

L.E. Stamets

California State Energy Resources Conservation and Development Commission

1111 Howe Avenue

Sacramento, CA 95825

J. Sell

Carolina Power \& Light Co.

336 Fayettesville Street

Raleigh, NC 27602

J. Morse

Catalytic Construction Corp.

P.0. Box 11402

Charlotte, NC 28029
No. of

Copies

H.H. Osborn

Combustion Engineering

Air Preheater Company

Wellsville, IVY 14985

R. H. Holyoak

Commonwealth Edison

One First Plaza

P.0. Box 767

Chicago, IL 60690

C.L. Newnan

Consolidated Edison Co. of New York, Inc.

4 Irving Place

New York, NY 10003

W. A. Messner

Consolidated Edison Co. of New York, Inc.

4 Irving Place

New York, NY 1003

F. K. Coore

Cornell University

Ithaca, NY 14850

R.J. Haberski

Curtiss-Wright Corp.

One Passaic Street

Wood Ridge, NJ 07075

S.K. Blackley

Duke Power Company

P.0. Box 2178

Charlotte, NC 28201

E. Guyer

Dynatech Company

99 Erie Street

Cambridge, MA 02139 
No. of

Copies

J. K. Swindt

Ecodyne Cooling Products Co.

San Rosa, CA 95403

J. Maulbetsch

Electric Power Research Institute

3412 Hillview Avenue

P.0. Box 10412

Palo Alto, CA 94304

L. Geller

Empire State Electric Energy Research Corp.

1250 Broadway

New York, NY 10001

M. Maxwe11 (MD-61)

IERL-RTP

Environmental Protection Agency

Research Triangle Park, NC 27711

F.H. Rainwater

Environmental Protection Agency

Pacific Northwest Water Laboratory

200 S.W. 35th Street

Corvallis, OR 97330

W. Hoydisch

Environmental Scjences and Services

43-44 37th Street

Long Island City, NY 11101

E.L. Damon

Fostor Wheeler Energy Co.

$110 \mathrm{~S}$. Orange Avenue

Livingston, NJ 07039

A.M. Rubin

Franklin Institute

Twentieth \& Parkway

Philadelphia, PA 19103
No. of

Copies

B. Davis

GEA Airexchangers, Inc.

46 Worthington Drive

Maryland Heights, MD 63043

A.C. Eulberg

General Atomic

P.0. Box 81608

San Diego, CA 92138

E. H. Miller

General Electric Co.

Large Steam Turbine Division

300 Nott Street

Schenectady, NY 12301

R.K. Shah

Harrison Radiator Division

General Motors Corp.

Lockport, NY 14094

J.F. Sebald

Gilbert Associates, Inc.

525 Lancaster Avenue

Reading, PA 19603

J.E. Taboric

Heat Transfer Research Inc.

1000 S. Fremont Avenue

Alhambra, CA 91802

E.C. Smith

Hudson Products

6855 Horwin Drive

Houston, TX 77036

M.W. Larinoff

Hudson Products

6855 Horwin Drive

Houston, TX 77036

W.R. Scott, Jr. Ingersol1-Rand

Phillipsburg, NJ 08865 
No. of

Copies

C. Rocco

Italimpianti - Societa Italiano Impianti p.a.

Piazza, Piccapietra 9

18121 Genoa, ITALY

J.L. Mul1oy

Los Angeles Department of Water and Power

111 N. Hope Street

Los Angeles, CA 90012

R.J. Meyer

Louisiana Power \& Light Co.

142 Delaronde Street

New Orleans, LA 70174

E.S. Miliaras

The Charles T. Main Co.

Southeast Tower

Prudential Center

Boston, MA 02199

R. Landon.

Marley Co.

5800 Fox Ridge Drive

Mission, KS 66202

L.R. Glicksman

Massachusetts Institute of Technology

77 Massachusetts Avenue

Cambridge, MA 02139

M.W. Golay

Massachusetts Institute of Technology

77 Massachusetts Avenue

Cambridge, MA 02139

R. Harleman

Department of Civil

Engineering

Massachusetts Institute of Technology

77 Massachusetts Avenue

Cambridge, MA 02139
No. of

Copies

A.J. Vander Weyden

McDonnel Douglas Astronautics Co. 5301 Bols Avenue

Huntington Beach, CA 92647

R. Hofacher

Montana Power Co.

40 E. Broadway

Butte, MT 59701

W.G. Hoydysn

New York University

University Heights

New York, NY 10453

W. Kals

Niagara Blower

405 Lexington Avenue

New York, NY 10017

R.H. Meyer

Northeast Utilities

P.0. Box 270

Hartford, CT 06101

L.P. Davis

Departinent of Mechanical

Engineering

Oregon State University

Corvallis, OR 97330

C. E. Wicks

Department of Chemical

Engineering

Oregon State Univserity

Corvallis, OR 97330

J.G. Knudson

Engineering Experiment

Station

Oregon State University

Corvallis, OR 97330 
No. of

Copies

J. W. Miche 1

OTEC Heat Exchange Project Activity

Oak Ridge National Laboratory Box Y

Oak Ridge, TN 37830

A.A. Ariey

Pacific Gas \& Electric

77 Beale Street

San Francisco, CA 94106

F.F. Mautz

Pacific Gas \& Electric

77 Beale Street

San Francisco, CA 94106

P.G. Humphries

Pacific Power \& Light Co.

Public Service B1dg.

Portland, OR 97204

D.G. Pfeitfer

Pennsylvania Power \& Light

2 North Ninth Street

Al lentown, PA 18101

T. Rozenmann

PFR Engineering Systems, Inc.

Suite 832

4676 Admiralty Way

Marina del Rey, CA 90291

Prof. Ing. Carlo Roma

Piazza delle Muse 8

Rome, ITALY

G. L. Henderson

Power Generation Cooling Systems

4714 - 52nd Street S.

Seattle, WA 98118

R.F. Walker

Public Service of Colorado

5900 E. 39th Avenue

Denver, CO 80207
No. of

Copies

J.D. Maddox

Public Service of New Mexico Corporate Planning Dept.

Albuquerque, NM 87103

G.E. Collins

Research Cottrel1

Hamon Cooling Tower Division

Box 750

Bound Brook, NJ 08805

R. Lindberg

Reynolds Aluminium Co.

Reynolds Metallurgical

Research Laboratory

Richmond, VA 23261

R.G. Lacy

San Diego Gas \& Electric

101 Ash Street

San Diego, CA 92107

R.L. Skone

Seattie City Light

1015 Third Avenue

Seatt7e, WA 98104

F.A. McCracken

Southern California Edison

2244 Walnut Grove Avenue

Rosemead, CA 91770

P. Sporn

Consultant Engineer

74 Trinity Place, Suite 511

New York, NY 10006

A. L. London

Department of Mechanical

Engineering

Stanford University

Stanford, CA 94305

J.Y. Parce

Stearns and Rogers

$700 \mathrm{~S}$. Ash Street

Denver, CO 80222 
iNo. of

Copies

D.H. Guild

Stone \& Webster Engineering Corporation

225 Franklin Street

Boston, MA 02107

H. I. Wilson

Tampa Electric Co.

P.0. Box 111

Tampa, FL 33601

W. Keel

Texas Electric Service Co.

115 W. Seventh Street

Fort Worth, TX 76102

A.A. Ward

Tucson Gas \& Electric

220 W. 6th Street

Tucson, AZ 85701

J. Bartz

Union Carbide Corp.

Linde Division.

61 East Park Drive

Tonawanda, NY 14150

G.J. Kidd

Union Carbide Corp.

ORGDP - K-24

P. 0. Box D

Oak Ridge, TN 37803

F. Notaro

Union Carbide Corp.

Linde Division

61 East Park Drive

Tonawanda, NY 14150

G.A. Englesson

United Engineers \& Constructors

1401 Arch Street

Philadelphia, PA 19105

K. Simhan

University of Bremen

Bremen, WEST GERMANY
No. of

Copies

\author{
J.F. Kennedy \\ University of Iowa \\ Hyrdaulic Research Institute \\ Iowa City, IA 52240
}

J.H. Hutchinson

Utah Power \& Light

1407 W.N. Temple

Salt Lake City, UT 84103

\section{S. Ragone}

Virginia Electric \& Power Co. $700 \mathrm{E}$. Franklin Street

Richmond, VA 23261

J.T. Kimbal1

Washington State University

College of. Engineering

Pullman, WA 99163

D.L. 01 son

Washington Water Power Co.

E. 1411 Mission Avenue

Spokane, WA 99202

G.H. Soule

West Associates

Sierra Pacific Power Co.

100 E. Moana Lane

Reno, iN 89510

J.A. Barnett

Executive Director

Western States Water Council

220 South 2nd East

Suite 200

Salt Lake City, UT 84111

G.J. Silvestri

Westinghouse Electric Corp.

Steam Turbines Division

Lester Branch

Box 9175

Philadelphia, PA 19113 
No. of

Copies

K.A. 0leson

Westinghouse Electric Corp.

Steam Turbines Division

Lester Branch

Box 9175

Philadelphia, PA 19113

L.E. Wilkinson

Consultant

6582 Ganon Street S.E.

Salem, OR 97301

\section{ONSITE}

ERDA Richland Operations Office Energy Programs Division

H.E. Ransom

Westinghouse Hanford Company

Hanford Engineering Develop-

ment Laboratory

J. Fletcher

70 Battelle-Northwest

R.T. Al lemann

P.A. Ard

D.J. Braun

J.W. Currie

D.E. Deonigi

R.L. Dillon

D.W. Dragnich

R.L. Drake

D.W. Faletti

J.W. Finnigan

B.C. Fryer

J.J. Hauth

A.J. Haverfield

C.H. Henager

A.B. Johnson

W.S. Kelly

R.S. Kemper

C.J. Knoll

W.V. Loscutoff

R.P. Marsha 11

D.E. Olesen
Battelle-Northwest (cont.)

Y. Onishi

L.T. Pedersen

H.C. Riches

J.B. Schuette

G.C. Smith

J.S. Stoakes

A.M. Sutey

D.S. Trent

M. Vagins

R.A. Walter

R.L. Watts

R.D. Widrig

L.E. Wiles

F.R. Zaloudek

File - B.M. Johson (30)

Technical Information (3)

Technical Publications 
